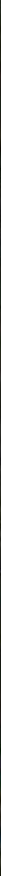


$149^{3}$ 
is

135

$$
\text { strion' }
$$



Old Days on the Farm

A. C. WOOD 




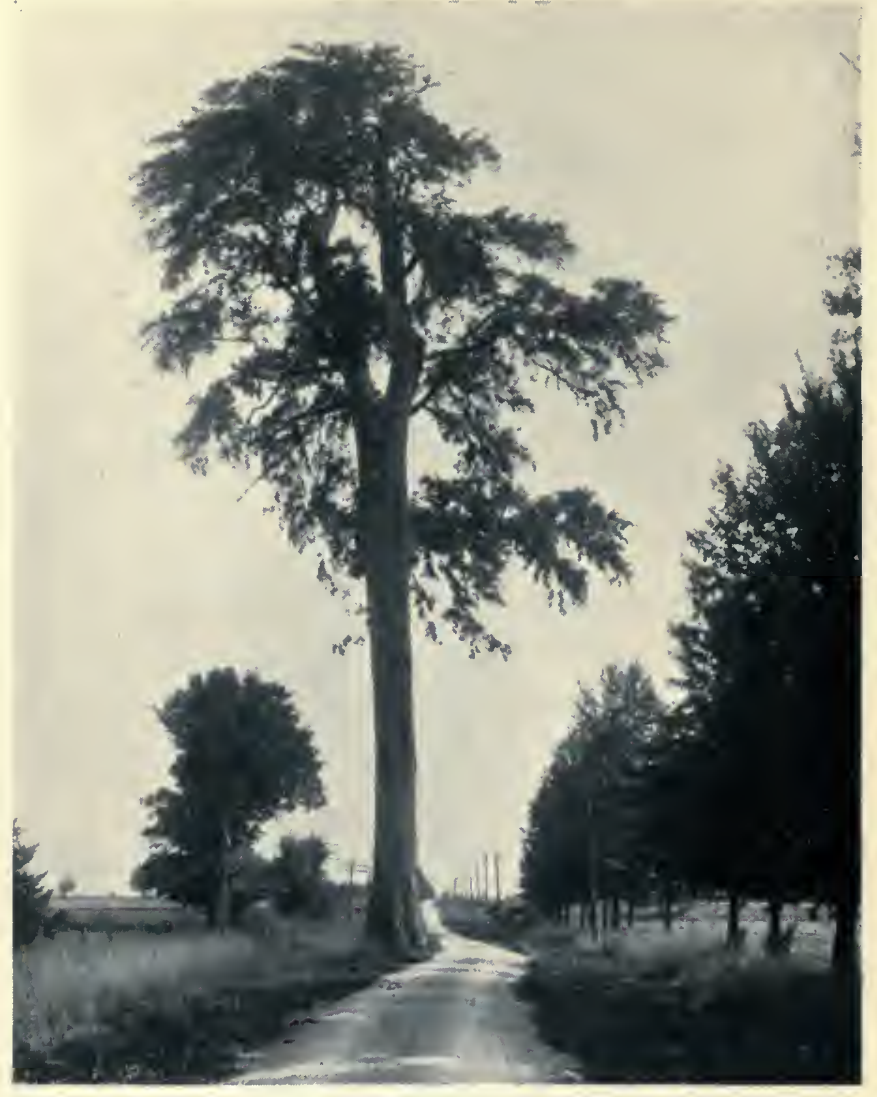

"THE WAYSIDE ELM." 


\section{OLD DAYS}

ON THE FARM

BY

A. C. WOOD

"Verily there are things no man can take from you, and among these are recollections and remembrances, and in your reflective years you will be happy or sad according as your recollections are pleasant or otherwise."

The Rural Philosopher

MCCLELLAND, GOODCHILD \& STEWART PUBLISHERS : : : : TORONTO 
Copyright, 1918,

By George H. Doran Compamy

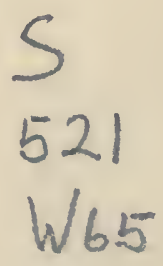

Printed in the United States of America 


\section{TO THE BALKING BUYER}

If rustic joys and rural themes, Adventures with the old ox-teams, And keen delights of hunting 'coons, And dances to the old-time tunes,

Have charms to please you yet Come, join with me, and, in this book, Let's wander back and take a look At country scenes of earlier days, Before our artificial ways

Had caused their sun to set. 



\section{PREFACE}

A SON of the soil, born in a log cabin and A bred on a bush farm, should have pleasurable recollections of boyhood days. Gazing' into the misty mirror of the past, I have endeavoured, in these sketches, in some measure to pay the debt of gratitude I owe the Goddess of Fortune for starting me off on life's journey amid such surroundings. I hold to the belief that one born and raised in the country -it may be in a log cabin and on a bush farm-has a distinct advantage over those unfortunates who, from infancy, have been doomed to artificial ways-city pavements-and so missed the delights of woodland places, hawthorn lanes and the innumerable joys that pertain to rural life.

Canada still has vast stretches of forest and plain invitingly awaiting the coming of the homemakers. And those dear, if homely and natural, pleasures that I have essayed to recall in these "Old Days on the Farm" chapters, are still, in a degree, to be found and enjoyed by those who may adventure in the field of pioneer agriculture. 
It is not my purpose, in this volume, to assist in effecting a back-to-the-land movement, but rather to present, in, it is hoped, an entertaining way, the pleasurable side of farm life, as I knew it, as a boy and youth.

St. Marys, Ont.,

A. C. Wood.

Canada. 


\section{AUTHOR'S NOTE}

T may be recalled that Josh Billings in his 1 famous essay, "What I Kno about Pharming," makes this open confession: "What I know about pharmin' iz kussid little." But there are few like the humorous essayist. Ever since the first pioneer felled the first tree in the forest primeval, there has been a crowd eagerly anxious to mount the stump and tell the farmer how to farm. If a man plants a hill of cucumbers in his backyard, or, as a boy, has helped herd the potato bug off the family patch, it just seems that he cannot restrain himself from telling the fellow in the furrowed fields how to make farming pay. This book does not give advice to farmers. Advice is the cheapest thing in the world, and so there is a price on this volume. Having driven the cows across the meadows sweet with clover, carried the cool grey jug to the harvest field of other days, and ploughed with an old ox-team, I had to struggle heroically to keep myself out of the armchair agriculturist class. But like Paul of old, I feel I have fought a good fight and won.

"Old Days on the Farm" was the title given a series of articles contributed to the St. Marys Journal, most of which articles, with changes and 
additions, are contained in this volume. Certain of my friends expressed a desire that these memory films be gathered in book form; that is the chief reason why this addition is made to the world's mountain of books, which mountain, it may be observed, is already vastly bigger than the Great Pyramid or "the stack behind the barn." Whether or no it meets the fate of the nine hundred and ninety-nine in every thousand and is ploughed under in the first edition, is of small importance. The pleasure afforded me in recalling the happy days of childhood and the romancehued years of youth, was, in itself, a rich reward. 


\section{CONTENTS}

CHAPTER

PAGR

I THOSE WHO LIVE IN THE COUNTRY

17

II COWS AND COURTSHIP ON THE OLD-TIME

FARM . • • • • • • 33

III UNDER THE OLD APPLE-TREE • • . 47

IV ON THE BANKS OF THE AVON • . $\quad 59$

V RED LETTER DAYS . . . . . 71

VI DAIRYING IN THE OLDEN DAYS . • . 87

VII STUMPS AND SNAKE-FENCES . . . 101

VIII A "SHOOTING MATCH" . . . . 119

IX THRESHING DAY .. . . . . 129

$x$ SWEET CLER AND "APPLESASS" . . 143

XI THE “' COON HUNTERS' " CLUB . . 153

XII THE CHAMPION 'COON HUNTER'S STORY 165

XII BY THE FIRESIDE . . . . . 175

XIV FAIRS OF THE PIONEERS • . • . 185

XV SCHOOLS OF THE THREE " $R$ 'S" . 197

XVI SONGS OF OTHER DAYS • • . . 223

XVII OLD WELIS . . . . . . 235

XVIII BEE-KEEPING . . . . . . 245 



\section{ILLUSTRATIONS}

"THE WAYSIDE ELM" . . . Frontispiece PAGE

IN OX-TEAM AND "SNAKE" RAIL-FENCE DAYS • 26 SHEEP WASHING IN A WESTERN ONTARIO STREAM 40 "A STREAM WITH MANY A SHADY POOL" • . 62 "BY THE VINE-CLAD DAIRY DOOR" . . . 90 THE HARVEST FIELD OF OTHER DAYS . • • 134 THE CIDER BARREL, THE SMALL BOY AND THE WHEAT STRAW . . . . . • 154 GETTING READY FOR THE HAYING • • . 204 WATERING THE HORSES • . . • . 244 



\section{CHAPTER ONE : THOSE WHO LIVE IN THE}

COUNTRY

JOYS OF THOSE WHO LIVE IN THE COUNTRY. ARMCHAIR AGRICULTURIST DEFINED. SOME GOSSIP ABOUT THE OX AND A CHRISTMAS DAY ADVENTURE, DOWN ON THE FARM. BREAKING IN A PAIR OF YOUNG OXEN. HOW SANTA CLAUS OAME TO AN EARLY SETTLER'S CABIN. 



\section{OLD DAYS ON THE FARM}

\section{CHAPTER I}

\section{Those Who Live in the Country}

T'VE always felt if there is one profession that 1 a man engages in on earth, about which he has reason to be proud above other men, it is the profession of farming. Please note that I'm using the word profession. You'd expect me to use calling, occupation, job, or some of those plebeian references, but not so. There is no word too patrician nor too high up on the language shelf, nor too exclusive, for that matter, not to be used when referring to the profession of those sons of toil who till the face of Mother Earth. It's the oldest of all the professions. You'll remember that Father Adam himself began it and the Good Book has innumerable references to it. The world's greatest poets have sung its praises, master painters have delighted in making pictures with sheep on the hillside, waving grain-fields, cows drinking at meadow brooks and other pastoral beauties, and great sculptors use scenes depicting this oldest profession for their finest frescoes in marble. 


\section{ARM-CHAIR AGRICULTURIST DEFINED}

I want to set it down as my proudest boast that I was born on a farm and on a bush farm at that. I may have dreamt at times that I would have liked to have dwelt in marble halls but I want to confess that among my sweetest recollections are of those days spent in and about the log cabin where I first saw the light. That may be enough to convey the intelligence to my farmer readers that I am with them, going and coming and returning back.

Now I am not posing as an arm-chair agriculturist. They are the chaps, you know, who try to tell the farming man how to make two blades of grass grow this year where only one grew last year and the year before. I may be wrong but it's my opinion that many of these members of the Arm-chair Advisory Board to Farmers couldn't tell a chinch-bug from a potato beetle or a pieplant from a burdock, in actual agricultural warfare. Likely most of them never pulled the earth about a hill of potatoes. They are full of-well, many big words ending in ology, ism and ics. Remember what Judge Haliburton in "Sam Slick, the Clockmaker," had to say about metaphysics as applied to agriculture. It's worth pinning on the milkhouse door. Sam Slick said this, "All the metaphysics in the world won't make a pound of butter." Was Sam right? If you can't decide ask the chap who works the churn. 
Meeting an old chum, a former country lad, from a big city the other day, he inquired kindly about former country friends. Among other things I pictured, with all the poetic eloquence I could command, what was going on in the country in this, the blithest time of the year-the sap running in the sugar bush, the syrup thickening in the evaporating pans, the brooks babbling music on their way to join the brimming river, the boys getting muskrats along the creek, the young lambs running races along the hillsides, the wild flowers appearing in woodland places and the birds a-singing in the trees.

$\mathrm{He}$ listened for a while and I could see a tender look steal over his features. Then he broke in:

"Say, old boy, those folks back in the country are the kings and queens of the earth. They've got moving pictures in natural colours all day long before them and they don't have to jar themselves on granolithic pavement every time they move about. Wish I'd stayed among them. Please don't tell me any more or you'll have me shedding tears."

I knew just how he felt about it and could sympathize. My little talk had set him thinking back and he'd had quick visions of hawthorns a-bloom, old swimming-holes, babbling brooks and woodland ways carpeted with wild flowers and the thousand other delights that crowd into the life of one 
so fortunate as to have grown up in the country. $\mathrm{He}$ had had memories of the days when he used to bring the cows up the lane and ride the horses to water.

I need not, therefore, bring forward innumerable and prosy arguments in support of the attitude that the boy or girl born and raised in the country has a distinct advantage over the cityborn.

But that's enough of essay and argument. This is not to be a volume for the furtherance of any back-to-the-land movement as I have already set forth. It purports to be a record of "Farm" reminiscences. My memory is not so good as that of the immortal "David Copperfield" who told his life's story from the day he was born with exact, minute and fascinating detail, but I can "think back" into the dim and distant, too.

\section{THE OLD OX-TEAM IN HISTORY}

Among my earliest recollections, that may be made public, are some particulars regarding the breaking in of a pair of young oxen. Non-poetical theme, surely, but highly dramatic in possibilities -wonder is that the moving-picture men hadn't beaten me to it. One of the old Latin poets, Horace, has set down a line, "Difficile est propric communia dicere," which I interpret to mean that it's mighty difficult to get the right words to illuminate a homely topic. But I'll try to give the 


\section{Those Who Live in the Country 21}

story as I have language to relate it, and I recall it for the reason that the modern farmer's son doesn't have any such fun in these artificial and prosaic days and also that I've always loved an ox-team since that, to me, historic occasion. I used to linger over that passage in history, as a schoolboy, about the great Roman general, Cincinnatus, leaving his plough team-of oxen-standing in the furrow and hurrying off to take command of the Imperial City's legions. I used to think it was real unkind to the "critters" that he hadn't turned them out to pasture, but I also felt that a man who could manage a team of oxen well was fitted to lead men or do most any other odd job that might happen along.

I pride myself on knowing a thing or two about oxen first-hand. I've helped break them to the yoke and I've also "driv" them many, many weary miles. Countless volumes have been written about the horse, and I remember that Bill Nye, the humourist, once addressed an "Apostrophe to an Orphan Mule." Wish I could recall the whole poem, but my memory has slipped a cog. It runs :

"Sing on, oh mule and warble in the twilight gray."

But somehow or other the ox does not occupy the place in literature that its importance seems to demand, at least not to those who know and appreciate that kindly, thoughtful and also, at times obstreperous animal. It is true it has had 
one of the world's most important waterways named after it-the Bosphorus-and some of the minor poets have chirped a few notes in its memory but - sic transit gloria mundi-so far as the ox is concerned, which being liberally translated means, the tail goes with the hide.

\section{"BREAKING IN" A YOUNG OX-TEAM}

But to get along with my earliest recollection story, I recall that, one Christmas Day, when I was a very small boy, practically a child in arms, "the hired man who worked for pa" announced his intention of giving the children of our household a festive treat. He had secured my father's permission to yoke up a pair of young bullocks to an old "long" sleigh and initiate the "critters" into the business of being of service to the world.

In these effete and highly civilised days, bullocks are stabled and petted while young, but in those "halcyon days of yore" - the good old days I mean, and like the words better,-most young cattle ran about a strawstack, all winter long and made a race track, in miniature, about it. No cyclist, motor-cyclist or auto manipulator could round curves with greater facility than those young bullocks I write of, and they had practised all sorts of buck-jumping and sudden, intricate and complicated movements on the stercoraceous heap-manure pile-in our barnyard. No 


\section{Those Who Live in the Country 23}

human hand had been laid with kindness on their proud necks and, just naturally, they bowed their maned shoulders to the yoke, when they were forced. After various gyratory movements about the barnyard the "critters" were roped by the horns to fence-posts and the big wooden yoke secured on their necks. The old "long" sleigh with its deep wooden box was brought forward and the log-chain made fast to the yoke and sleigh. Then all hands tumbled into the pea-straw on the bottom of the sleighbox and the lines were cast off. That's a nautical expression, "the lines were cast off," but it goes in this case, because there we were embarking on an overland voyage without bearings and no port in sight.

One of the poets has set down some verses; one of which runs:

"Where lies the land to which the ship would go? Far, far ahead is all her seamen know, And where the land she travels from? Away Far, far behind, is all that they can say."

If I'd been old enough to have become acquainted with verse at that time when those oxen were turned loose, I'd likely have thought that these lines fitted our case exactly, but I'd had to have done some quick thinking, as I recall that my time was mostly taken up with trying to hang on to the young folks about me in the bottom of that sleigh.

Let me explain that our farm had on it, at that 
time, stumps at irregular intervals in the back fields, also snake fences and some trees. The snow was two or three feet deep on the level, with many drifts, and the horned steeds were headed towards the tall timber. My recollection is that we just hit the high places - the crests of the snowy billows-besides, of course, colliding with numerous stumps and missing many trees by the narrowest of margins. Talk about the speed of an eightcylinder seven-passenger automobile with a limousine top, on an asphalt roadway, with no hostile policeman to hold up a warning hand-those oxen and that sleigh were sure travelling faster'n that and then some more. Snow was flying, the young oxen were snorting, when they weren't bellowing, and we children were all shouting, except, perhaps, some who were stricken dumb by the excitement and novelty of the situation.

A Chinaman is said to have described a trip on a toboggan slide in these terse words, "Zip, walkee, backee milee!" But we didn't walk back. After an exciting and flying-passage we collided head-on at the edge of the woods with a large tree and the outfit came to a very sudden stop with an ox on each side of that tree. The animals were panting and had their tongues hanging out, but they had learned their first lesson and actually were agreeable to standing still. The man at the helm-he with the whip-got out and patted the creatures and whispered words of love. 
Scientists and psychologists are, I believe, not agreed about the exact working of the mental processes of the lower animals, but I am quite fixed in my belief that those young oxen were not wholly in love with mankind at that moment. After a spell the outfit was headed towards the barn. Needless, perhaps, to state, having gathered their "second wind," the young "critters" moved with undiminished speed. They took no notice of a sapling that stood directly in their course in one of the fields. They ran fair onto it and it bent down before the yoke. Their speed was so great that they were carried several feet along that bent-over tree and suddenly found their front feet touching nothing. There was that team of oxen standing on their hind legs in the snow with their forward ends up in the air. It was a critical moment, as the uplift of the tree brought the bows of the yoke so tightly against their necks that they were nearly strangled. One of the party was detailed to bring an axe from the nearby barn and a few swift strokes at the root of the tree let the animals down on all fours.

It was a quite demure and seemingly quite tame pair of young oxen that returned to that barnyard that never-to-be-forgotten Christmas Day, and that joy-ride furnished a theme for many an animated conversation among the young folks of our household for weeks afterwárd. 


\section{BLAMES THE OX FOR SO MANY HOTELS}

I was more than surprised the other day when an old-timer had the effrontery to blame the old ox-team for the existence of so many hotels on the bush-roads of this country in pioneer days. He argued it out this way, that as the thoughtful ox had to think twice before it put one foot before the other, that progress by ox-team was exceedingly slow and, therefore, even with hotels at nearly every cross-road in other days, it was, as the Guv. of North Carolina said to the Guv. of South Carolina a long time between-well, you know the rest. He argued further that the shouting and, well-heated language-that an ox-driver had to use made much "wettin' o' the whistle" an absolute necessity.

It was a mean insinuation and I'd resent the allegation of that old-timer if he were as old as Methusaleh. I'm with the ox-on the left side too-first, last and around the stump.

\section{AN OLD-TIMER'S CHRISTMAS STORY}

A pioneer once told me a Christmas story in which the old ox-team played a leading part.

As nearly as I can recall it he gave it thus:

"I've read them wonderful Christmas tales o' Charles Dickens's an' that there one o' Bret 


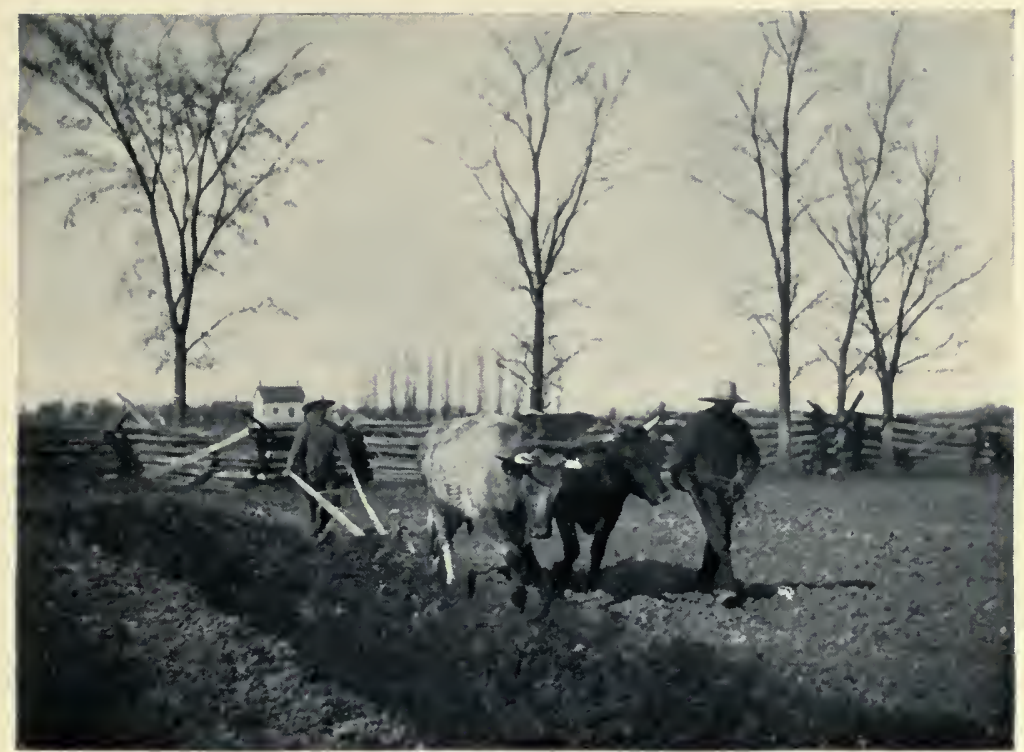

IN OX-TEAM AND "SNAKE" RAIL-FENCE DAYS. 

Harte's, 'How Santa Claus Came to Simpson's Bar,' but I've never heard of any o' the great story-tellers puttin' an old ox-team into a Santa Claus yarn. Guess it's 'cause them horned critters don't travel fast enough. As ye know, they are some slower'n reindeer an' bronchos. Likely that's the reason.

"This little incident that I'm proceedin' with happened 'way back in the early days when blazed trails was numerous an' snake an' brush fences lined what roads we had. I was jest a youth then an' I wasn't an only child either. Only-child families wasn't the fashionable kind with the pioneers, an' our family averaged up pretty well fer size, with me the oldest $0^{\prime}$ the bunch.

"Our log-cabin on the bush farm was jest about filled to capacity an' was several miles from the nearest village.

"Fer days an' days before Christmas that year it snowed an' blowed. The wind jest seemed to have completely lost control o' itself an' tore through woods an' clearin' pilin' the snow up in tremendous heaps.

"There wasn't well-filled cellars below the cabins $o^{\prime}$ the pioneers them times an' our provisions, 'ceptin' deer meat, had been runnin' low when that storm came on. Jest the mornin' afore Christmas mother had turned the oatmeal bag inside out to get enough fer the breakfast porridge. Dad looked kind o' anxious when he saw the last 
$0^{\prime}$ that meal go in the pot an' after breakfast said to me:

"' 'Joe, you an' me'll have to get to the village. Ain't goin' to have no starvation in this shanty with two able-bodied men around and besides tonight Santa Claus is due. Yoke up the steers, put the long-handled shovel an' a whole lot of peastraw in the sleigh.'

" 'An' say, Joe,' he called after me as I started for the stable, 'guess ye'd better put a new buckskin cracker on the whip. Them consarned critters 'll do a lot of crowdin' in the deep snow an' we'll have to kind o' take up their attention from behind.'

"There was nary a horse-team in the settlement then, but jest contrairy horned critters an' homemade jumpers an' long sleighs. Brave hearts didn't beat under coonskin coats nor feet keep warm 'neath Arctic robes in them times. Well, I guess not. Fulled cloth, homespun an' pea-straw were the materials in use when Dad an' me piloted that yoke o' steers along the blazed trail and over the roads lined with brush an' snake railfences.

"I've gone to dances 'way back in log-shanty days when we had to carry the girls in our arms through snowdrifts 'cause we couldn't get our teams through with the load on, an' I've passed through a good deal o' strenuous weather at one time or another, but that trip Dad an' me made for Santa Claus an' oatmeal for the kids stands 
out in the foreground o' my memory a little the most prominent o' my experiences on the road.

"Talk about navigatin' a schooner in a livin' gale with a sea beatin' on the wrong quarter'tain't nothin' compared to drivin' a yoke of cattle along a drifted bush-road with a cuttin' head wind.

“Dad an' me hadn't gone more'n forty rod before them cattle began to act up. They crowded each other off the track. First Buck would be over in the deep snow a-wallerin' an' a-puffin'. Then he'd get an underholt on his mate an' hist him off the track. At times they'd both be off the road. Didn't seem to care no more for the whip than if it had been a stalk o' timothy Dad was wieldin'.

"It took us plum four hours to make the village an'.I'd done enough o' road work to let us out o' statute labor for ten years. In one scrimmage with a big drift old Buck's yoke pin worked out and that meek-eyed old chap, when he found himself free of the yoke, wheeled about an' cut for home. Dad held the other fellow while I undertook to round up that home-lovin' ox. He gave up the run after half a mile o' back track had been covered an' then it took us about half an hour longer to find that yoke pin. An' all the while it was blowin' an' snowin'.

"Talk about your difficulties o' travel these days. Pshaw! it's like roller-skates an' a revolvin' track compared with the days when Dad 
an' me fetched that Santa Claus truck and oatmeal home.

"But Santa Claus arrived at our cabin in the woods an' no horses, reindeer or any other drivin' critters would have got through them snowdrifts 'ceptin' the ox-team." 


\section{CHAPTER II: COWS AND COURTSHIP ON THE OLD-TIME FARM}

COWS AND COURTSHIP. COWBELLS AND WEDDINGBELLS. THE MILKING HOUR AND THE DAIRYMAID. COWS AS WEDDING GIFTS. A RUSTIC LOVE SCENE. CUPID AT THE CHURN. OLD BOSSY IN LITERATURE. THE OLD SINGING SCHOOL. TRUSTY OLD NAG VERSUS AUTO IN COUNTRY COURTSHIPS. IN DEMOCRAT AND LUMBER WAGON DAYS. THE MOON AND GIRLS DON'T CHANGE. 



\section{CHAPTER II}

Cows and Courtship on the Old-time Farm

WOULD it be termed a presumptuous folly, to link together cows and courtship when considering love affairs on the old-time farm? It does scarcely seem reasonable to expect that the ting-aling a-linging of the discordant, unmusical, tinkling, jangling cowbell could be made to harmonize with the joyous jingle of the merry wedding bells. And yet there does seem a not unreasonable reasonableness in such a conjunction, when all the facts are adduced.

\section{THE FAVOURITE TRYSTING-PLACE}

Cows and courtship! cowbells and wedding bells! Well, there's a reason-to steal a phrase from the cereal man-for linking these together. Of course, if you were so unfortunate as to have been born anywhere else than on an old-time farm the reason will have to be made clear to you.

Perhaps you may not know that the favourite meeting-place for lovers there was at the bars at the end of the lane, and when the sun was sinking. low, and when the birds were cooing to their mates 
in the trees and when the milking hour had come. But it's true.

\section{THE MIKING HOUR}

You see in the olden days the young women of a farmer's household did most of the milking and a milking hour lover was sure to be doubly welcome. He could help milk and also came in handy in carrying the brimming pails to the dairy or milkhouse.

By the vineclad dairy door

Jo's young heart is brimming o'er

As he tells the tale 'at's older'n the hills-

And he loves the milking hour

As the flowers a summer shower,

Or as chub and sunfish love the babbling rills.

He, for Phyllis, bears the pail-

Sweetest girl in all the vale;

He has hopes that some day she will be his bride,

So Jo lingers by the bars,

Not to gaze at moon or stars,

But to court the pretty milkmaid at his side.

\section{COWS AS WEDDING-GIFTS}

And more than this, in arguing my case, let me state, that time was, whenever a country girl became a bride, that a gentle, cud-chewing, milkgiving So-bossy was certain to be included in the list of wedding-gifts. Also, it may be remarked, that for actual practical assistance in making the 
Cows and Courtship on the Farm 35

trip over the double trail, such a gift has some advantages over casseroles, cut-glass vases or goblets, sunbursts, mantel-clocks and other bric-à-brac. It really wouldn't be a bad idea to revive that old custom but it would be costly with cows worth a hundred dollars per.

\section{'TWAS EVER THUS IN CHILDHOOD's HOUR}

I recall that the first agricultural or pastoral possession that came my way - that is, that I called my own, was a wee, red wobbly calf. Most every boy born on a farm has a calf presented him by his fond parents-later on when the calf has horns -well, as Kipling says, that's another story. The other story is that when that calf becomes merged into the farm herd, as full-grown, its ownership somehow changes, and the aforesaid parent "takes back the calf he gavest thee." Ah, well, 'tis ever thus in childhood's hour, we see our fairest hopes decay, the calves we fondly claim as ours, are always sure to stray away-into the general herd. That's where mine went. If I'd been born a girl and married in the good old days, of course I'd have led away the cow.

Before dairying became the main business of the farmers of Old Ontario, and when grain was the chief product of the farm, the cheese factory cheque and the butter money, usually, were looked upon as the rightful property of the farmer's wife and daughters. 


\section{FAVOURITE NAMES FOR COWS}

The women of the farmer's household quite naturally looked upon the cow with favour and there wasn't any name in fiction or poetry so sacred or sweet sounding that it might not be bestowed on the milking herd. Rose, Spot, Lightfoot, Betsey, Mary, Chloe, Phyllis were in common use, and I recall that a merry milkmaid I once knew, called her favourite, Queenie. She'd been reading Mary J. Holmes's or Miss Braddon's luscious love tales, I guess.

\section{A RUSTIC LOVE SCENE}

'Just here allow me to interpose a burlesque on a rustic love scene:

He met her in the pasture lot Just as the sun was setting red;

He wore a home-made, big straw hat, She'd nothing on her shapely headThey walked together up the lane, They didn't smile or say a wordThe beating of their own glad hearts Was, maybe, all the sound they heard; He didn't help her o'er the stile, Instead he let down all the bars, Her mild eyes, meantime, fixed on him As iridescent as the starsNor thanks she spake, nor kiss she gave, In fact, I doubt if she knew howHe was a simple country lad And she-a dark-red muley cow. 
Cows and Courtship on the Farm 37.

CUPID EVEN ABOUT THE CHURN

Of course love-making was everywhere in the olden days, at least where there was a man and a maid-more particularly if the maid were a sweet, pretty cream-of-the-country-society milkmaid. Cupid was afoot in the hawthorn lane, in the shade of the old apple-tree, in the farm parlour and the dairy, as well as at the bars at the end of the lane.

In my scrapbook I find a fragrant little poem entitled "Love-making at the Churn," which tastes as sweet as butter and as good as bread. Jim knew Mary's churning day or evening, as the case might be, and came across the fields, with light springing footsteps, to help her at the task. Likely they made poetry or sang love-songs while they worked the old-fashioned churn-dasher. The touch of her hand would be a thing divine and he'd drink of his love as men drink wine-or rather buttermilk. Any young fellow who would help a pretty dairymaid make condensed sunshine--butter, I mean, couldn't fail to win his way in love affairs and agriculture.

HER SWEET VOICE CALLING CO-BOSS-CO!

Then there was Jo, on the next farm to Manda, he'd hear her sweet voice calling Co-Boss Co! and stop the plough to listen to the milking call. Sure thing, cows and courtship-cowbells and wedding bells, were more or less linked up in the love 
affairs of the young folks of earlier days down on the farm. I'd like to be able to spill out a lyric poem on the subject but I wasn't born that way, and beside, I left the farm too young to have had any meetings in the hawthorn lane or to have watched the sunset and, incidentally, the milkmaid, while leaning over the bars at the milking hour. But I can see 'em in my mind's eye for I was born down on the farm and heard the tinkle of the cowbell and drove the cows across the meadows deep with clover.

\section{OLD BOSSY IN IITERATURE}

But as this little rhapsody or rambling composition is not wholly about courtship at the bars or dairy or churn, let's get back to the cow for a spell. Old Bossy is easily the most important of all the lower animals upon the green-carpeted footstool of the Great Creator, and there is, to me, quite a clear connection between the gentle cow and the love affairs of country young folks, at least, of the period of which I write.

There is more mention of the cow in books than of any other animal, bar none. I could call up a dozen poems on "Milking Time" and about the animal that makes such a time possible. Artists are forever putting her into pictures, too, and all her comings and goings are pleasurable to behold.

The poets, particularly, among the great men of the earth, have considered the cow. You re- 
Cows and Courtship on the Farm

member that nursery rhyme, "Consider, good cow, consider."

\section{MUCH BUTTER-FAT IN HIS POETRY}

They used to have a poet in Oxford, Canada's banner dairying county, whose poetry was said to have more butter-fat to the line than any other rhymster could skim from off his think-tank. He published a volume of rhyme about cows, and curds and cream. He was the laureate of the dairy and the cow poet par excellence. Consider the ethical quality of this verselet from his pen:

"The cow is a kindly creature!

Kind and gentle in each feature,

About her is a homely charm,

And her the dog should not alarm.

But let all guard her from harm,

The gentlest creature on the farm."

Even that prince of romance, Robert Louis Stevenson, turned aside from the ways of pirates and bloodthirsty adventurers into the old cow path that ran crooked to the woods. He it was who wrote verses entitled "The Friendly Cow."

And that writer of exquisitely beautiful essays on nature, John Burroughs, has a charming prosepoem entitled, "Our Rural Divinity"-the cow.

Have I made good my presumptuous folly of naming cows and courtship in the same alliterative line? 
Certainly there were occasions on the old-time farm when Old Bossy had nothing whatever to do with the affairs of Cupid. There were the singingschool, the fall fair, circus day and the neighbourhood picnic.

\section{THE OLD SINGING-SCHOOL}

I was not so fortunate as to have attended singing-school in my boyhood days but I recall that older members of my family did, and that they used to practise do re mi fa sol la si do, with much gusto upon the organ in the old farm parlour. The neighbours' boys and girls would drop in of an evening for practice, too. The classes were held at the village church, weekly or fortnightly.

Old folks used to say those singing-schools were more for courting than for learning to raise tuneful voices in hymns of praise, and, it may be, they were right.

Eugene Field in one of his poems describes a young lady of the singing-school thus:

"Eyes as black as Kelsey's cat and cheeks as red as fire!

She had the best sopranner voice I think I ever heardSung 'Coronation,' 'Burlington' and 'Chiny' like a bird;

Never done better than with Bill a-standin' nigh 'er A-holdin' of her hymn-book so she wouldn't lose the place,

When Bill sung tenor and I sung bass." 


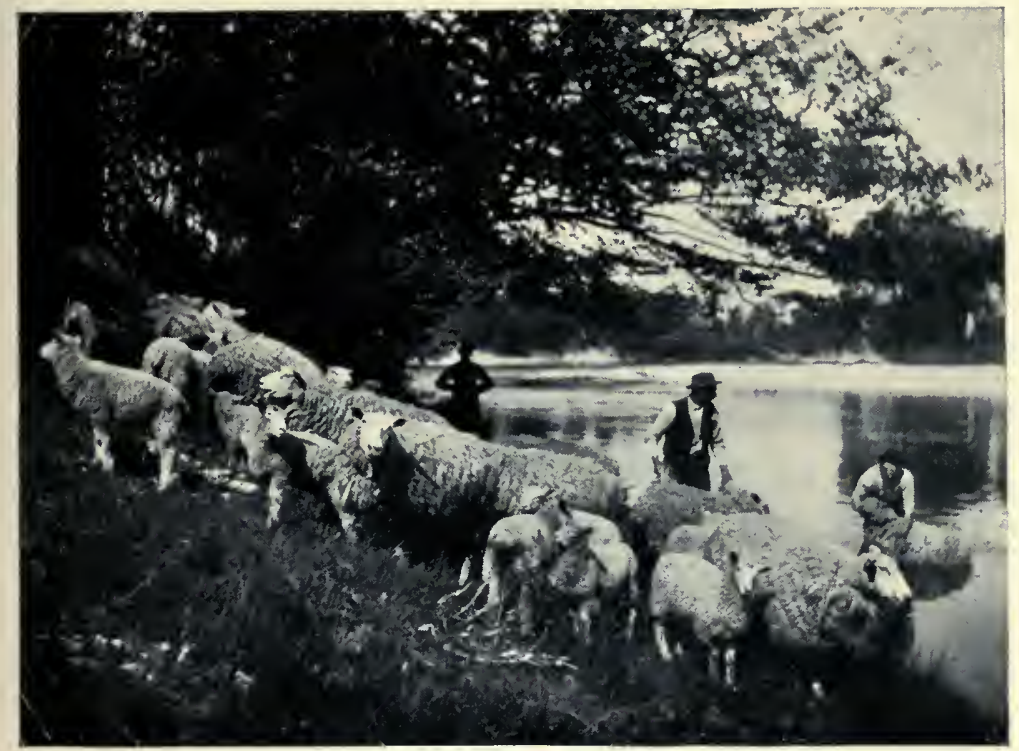

SHEEP WASHING IN A WESTERN ONTARIO STREAM. 

It was usually in winter when the singing classes were held and some of the boys had horses and cutters. It would have been hard to beat a trusty old nag and a comfortable cutter with "comfy" robes, in the golden olden days, as the shortest way to a country girl's heart, and some years later in our civilisation, the good old buggy in fall or summer was the king of siege artillery in love affairs. Talk about autos, you gay Lotharios of to-day! High speed and burning up the roads shouldn't count with the right kind of a girl and I don't believe it does. Why, you've got to have both your hands on the steering-wheel and your eyes fixed on the road and your love whispers are drowned in the whirring and sputtering and chugging of the vile-smelling engine. The fellow with the slow old nag-a long, winding, tree-shadowed road-has an indisputable advantage. He can even drop the reins.

Don't tell me, you fast-moving lovers of the twentieth century, that you've out-distanced those singing-school boys a-going down the primrose way-Lover's Lane, I mean. I won't believe it.

THE MOON AND THE GIRLS DON'T CHANGE!

The old horse will win in a love canter yet, every time, and the hawthorn lanes and the moon are a combination that just cannot be beaten. 
"When Homer twanged his tuneful lyre The moon was just the same as now, And girls set manly hearts afireThere's been no change, you must allow. I've read the gush those poets wrote From Chaucer down to Tennyson, Of girls and moon there's not a note But shows they work in unison."

Needn't tell me, either, you town and city folks who actually name some of your artificial and, sometimes, none too attractive side streets, Lovers' Lanes, that these are to be compared with hawthorn lanes. Pshaw! Lovers' Lanes with granolithic pavements and electric lights! Come, now, how do these match up with hawthorn lanes and the sweet silvery light of the moon?

It's just like naming the auto in the same breath as the slow old trusty nag. Your city Loviers' Lanes! Faugh!

\section{IN DEMOCRAT AND LUMBER WAGON DAYS}

And just think, too, of those rollicking rides with the girls those boys of other days had when they went to fair or circus in the democrat or lumber wagon. Now, don't say me nay! because even I-who am not a patriarch yet-can remember when there was not a single top buggy in my native township. Yes, the boys and girls in my youth actually did go to the fair and circus in the vehicles I have named, and they went with joy in their hearts, too. 
Instead of chocolates at a dollar a pound they'd eat bull's-eye candy, molasses taffy and talking lozenges-these latter were very much in favour with rural lovers in the good old days and assisted modest and shy maids and bashful youths, too, in carrying on a conversation. The printing or reading on those candies of a bygone day was highly sentimental. Some crabbed old bachelor might wish to substitute "soft" or "mushy" for "sentimental," but of course proper allowance must be made for such. He is not used to sweetness long drawn out like molasses taffy and love caresses and those talking lozenges were doubly sweet. They tasted that way and had honeyed words on 'em, too. Instead of fruit sundaes and varicoloured drinks from the soda fountain those rustic swains treated their girls to the real old simon-pure hand-made lemonade.

Then when the day at the fair or circus was over those boys of the democrat and lumber wagon days,

"Having tilted love's flagon Would jump in the wagon For a rollicking ride with the girls." 



\section{CHAPTER III: UNDER THE OLD APPLE- TREE}

'NEATH THE SHADE OF THE OLD APPLE-TREE. THE FAVOURITE SPOT ON THE OLD-TINE FARM. SUNKIST APPLES. THE FAVOURITE APPLE-TREE WITH PIRATES IN IT. ROSY-CHEEKED APPLES AND BOYS. THE PLANTING OF THE APPLE-TREE. PARING BEES AND APPLE PIE. A LITTLE GIRL'S DEFINITION OF GRAFTING. ORCHARD'S THE PLACE. 



\section{CHAPTER III}

\section{Under the Old Apple-tree}

TF a vote had been taken to determine which par1 ticular place of all places on the old-time farm was the favourite one with the small boys there would have been an unanimity of expression in favour of the apple orchard, that is, if the small boys had been consulted. The girls of the farm household, would, of course, have been in favour of the old-time flower garden.

Time was when I could name every tree in the old orchard at home and most of those in many of the neighbours' orchards as well. You see in those good old days there was a form of community of interests in each other's orchards, in so far as the boys of the neighbourhood were concerned.

It must be said for the pioneer farmers of Canada, that having disposed of the forest trees, they at once proceeded to plant fruit and ornamental trees with rare judgment, as to variety, and they cared for and cultivated those nurslings with meticulous method. The results were that in olden days there were excellent orchards on most farms. There were not so many parasites and pests then, and this country had apples, plums, pears and cherries which for flavour, size, 
appearance and general excellency, have never been surpassed in any land under the sun.

\section{"SUNKIST" APPLES}

I recall that all apples were "sunkist" when I was a boy-harvest apples, fall apples and winter apples. There were astrachans, sweet boughs, seek-no-furthers and pippins galore in the orchard that $I$ knew. But $I$ have in mind one tree, in particular, that I've always associated with that popular old song " "Neath the Shade of the Old Appletree." I presume, because I practically grew up under it, that it was the first tree I ever climbed and the favourite in our orchard. It had broad, spreading branches and bore the biggest, mellowest, yellowest, sweetest, juiciest and finest-flavoured apples that a small boy ever buried his young face in.

Naturally, a fellow of my age would have had many, good, bad and neutral tastes in his mouth during the journey along life's trail, but I want to state that I have never gotten away from, nor forgotten, that finest of all tastes that ever tickled my palate-the taste of those big, juicy "Sweet Bough" harvest apples. I am not alone in this. Quite recently I met, from a far eastern city, a gentleman who used to visit my home when a small boy and whom I had not seen for years. Almost his first words were:

"Say, old chum, is that harvest apple-tree grow- 
ing yet? You know the one I mean-that one with those big, mellow, sweet apples with a flavour like ambrosia and nectarine mixed. I think about those apples every time I see or eat an apple and wish I could get a taste, like those gave me, once more."

Of course, it's quite likely, there are just as good apples on earth now but the joys of boyhood were associated with those he and I talked about, and that makes a vast difference.

\section{THE FAVOURITE APPLE-TREE}

I've read that in the dim and distant past men. worshipped trees. I could find it in my heart to forgive a man for idolatry of this kind if it were such a tree as I knew in my boyhood hours. As a haby I toddled about in the grass under its shade and as a boy I climbed it.

“'But th' ol' tree's dyin', An' th' birds 'll come a-cryin' Fer their nesses, in its branches,

in th' early spring in vain: An' ther' can't be any apples Like them sweet yeller apples 'At grew in our farm orchardan' ther' won't never be again."

\section{A "MEMORY" TREE}

I suppose that every boy who has been raised on a farm and, somehow, wanders off into town or 
city life, has just such a "memory" tree as mine -one with the branches hanging down till they dipped in the blooming clover and the trunk just as twisted as an apple-tree can grow. Never was any colic from apples off that old tree-leastwise none of us boys ever had it, as I remember, and we often ate till we just couldn't swallow another mouthful.

\section{"PIRATES" IN THE APPLE-TREE}

On holidays and Saturdays when a bunch of us hungry young scamps would get together we'd play at "pirate" and "frigate" up among the limbs of that fine old tree and pour hot volleys into the crews of our opposing ships. After the buccaneering pirates had been pelted, so they had to seek shelter behind the old rail fence, we'd divide the booty and, believe me, it was no makebelieve pieces of eight from a pretended pirate chest. Every apple-tree sailor would have his little blouse full of round shot-golden treasurein the form of big, mellow harvest apples, gathered up from the clover below the towering topmasts of those apple-tree ships.

\section{LOOKING BACKWARD}

A country boy who leaves his home to seek fortune in town or city, quite naturally casts many a loving, lingering look behind, and, when he 
thinks of the old home, he just cannot help letting his thoughts hover about the old orchard and, particularly, about his favourite apple-tree. And when he comes back to spend his holidays in the good old summer-time, the orchard is, of course, the first place on the farm he visits. With what pride and fond recollection he asks his city chums to try those apples which mother and father sometimes send him and what a glow of pleasure it gives him to tell about the old orchard down on the farm.

\section{ROSY-CHEEKED APPLES-AND BOYS}

Seems like to me all the great poets have had apple-tree memories, at least most of them have had kind and loving words to spare for such references. There's Solomon, Old Omar, Bill Shakespeare, Lord Byron, Bobby Burns, Whitcomb Riley, Gene Field, Sam Foss, Bayard Taylor, William Cullen Bryant and a whole lot more of the writing, rhyming tribe who have had lingering memories of orchard trees. Natural thing, you know, for a fellow who has been a rosy-cheeked boy, when he gets to thinking back about the days when he, himself, had such cheeks, to recall memories of rosy-cheeked apples-seem to run together somehow and isn't it just fine that they do. Rosy-cheeked boys-and girls if you wish-and rosy-cheeked apples! 
THE PLANTING OF THE APPLE-TREE

If, dear reader, you have not read that enticing poem of William Cullen Bryant's, entitled, "The Planting of the Apple-tree," please do. When I read those noble and inspiring verses I realize how weak and puerile are my efforts to pay the tribute due to that favourite tree of my boyhood. I shall take the liberty of giving a few lines from his fine poem:

6 "What plant we in this apple-tree?

Fruits that shall swell in sunny June,

And redden in the August noon,

And drop, when gentle airs come by,

That fan the blue September sky,

While children come, with cries of glee, And seck them where the fragrant grass Betrays their bed to those who pass At the foot of the apple-tree.

6 "Who planted this old apple-tree?' The children of that distant day Thus to some aged man shall say; And gazing on its mossy stem, The grey-haired man shall answer them:

'A poet of the land was he, Born in the rude but good old times; 'Tis said he made some quaint old rhymes, On planting the apple-tree.' "'

MORE OF THE HEART, THAN HEAD

Why don't you give us some facts instead of all this sentiment and poetry, asks some disciple of 
Mr. Gradgrind-that facts, facts, facts character in that wonderful book of Dickens's, entitled, "Hard Times." Let me say to such a one that memories and reminiscences are more of the heart than the head, more of the emotions than the reason. Facts are cold, heartless things, anyway, and are entirely out of place in a "greyhaired boy's" recollections of the tree that bore the mellow, golden apples of boyhood and youth. A fig for facts! The assessor and tax collector deal in facts, but the possessor of a memory tree in the form of a fine old harvest apple-tree-has something too priceless for the assessor to value, and far, far removed from roll of the hard and stony-hearted tax collector.

\section{APPLE-PARING BEES AND APPLE PIE}

The orchard, as every schoolboy knows, made apple pie and apple dumpling possible, and there are those other direct products, sweet cider and dried apples. Yes, indeed, we owe a whole lot to this favoured part of the farm.

I remember the apple-paring bees of pioneer days when the apples were peeled and quartered by hand and strung on red cord to be hung in festoons about and above the kitchen stove to dry. The neighbouring young folks would all be invited to assist in the proceedings and afterward to enjoy the pleasures of a country dance. There would be deep apple pie with cream, for luncheon, 
apple turnovers and sweet cider. Could these be beaten for a lover and his lass, or any one else, with rational, healthy appetite?

"When mother made us apple pie,

In those old days down on the farm-

Sweetness and goodness mixed. Oh, my!

I'd eat a whole one without harm.

If I had realms to give away,

I'd hand them out without a sigh

To have her call mo in from play

And fill me up on apple pie."

"PUTTING OTHER LIMBS ON A TREE"

Seems like farmers in earlier days took a far greater interest in their orchards than they do today. Too intent now on money-making, I guess. I recall that my father rarely ever went a-visiting anywhere in the spring-time that he didn't bring home some apple twigs for grafting and many farmers were adepts at that somewhat delicate operation. To-day they mostly bire such work done and so, to some extent, lose a real interest in the process and results.

I was amused the other day while a little girl friend of mine was telling me about the pleasure a trip to the country had given her, at her naïve remark about grafting:

"And, Mr. Wood, do you know what I saw? I saw a man putting other limbs on a tree," was the way my little friend put it. If she had heard the word "grafting," she'd forgotten it. 
Yes, of all the places on the farm, the orchard's where I'd rather be, and one could almost wish that immortality had been given to the old orchard apple-tree in the branches of which the joys of childhood hang about in festoons, that only fade and wither when memory departs.

\section{THE OLD FARM ORCHARD}

There can't be any orchard Jes' like our old farm orchard 'At Dad planted many years ago around the old farm home; An' never wuz sech apple-trees, Here, er fur across the seas, Er anywheres a wanderer might on this old earth roam.

'Long about in May time Th' merry month o' May time!

Th' blossoms in that orchard would sure give ye dreams $o^{\prime}$ heaven;

Air so filled with odour $\mathrm{O}^{\prime}$ applebloom an' clover, It would make a chap o' forty feel like a kid o' seven.

One tree I well rememberAn' th' mem'ry makes me tender, Very first tree 'at I climbed while yet a teeny, weeny boy, Its branches hung low over A sea $0^{\prime}$ crimson clover, An' up there I found a robin's nest an' shouted loud in joy. 
Jes' loved that "Early Harvest"

Better far 'n all the rest,

Its branches helped me learn to walk,

I played beneath its shade,

Its apples were so yellow,

So juicy an' so mellow,

An' jes' the finest grub fer boys the good Lord ever made.

Couldn't git a dose o' colic, So 'twas always fun an' frolic When we met about that apple-tree with boyhood on the throne;

If I had crowns to give away, You could have 'em any day

Fer jes' one single golden hour of the life 'at I have known.

At my sister Mary's weddin' That ol' tree it stood a-sheddin' Pink an' white cascades $0^{\prime}$ blossom down upon the happy pair;

It wuz one o' sister's fancies To be wedded 'neath its branchesNever wuz a purtier weddin' er a bride 'at wuz more fair.

But th' fine ol' tree's a-dyin' An' I'm very near a-cryin' When I get to thinkin' back upon the happy days o' yore-

If there's a harvest apple-tree

Where Dad an' Mother wait fer me, In its shade I hope to meet 'em when I reach the other shore. 


\section{CHAPTER IV : ON THE BANKS OF THE AVON}

THE LURE OF FISHING FOR THE SMALL BOY. COUNTRY LAD PRAYS FOR RAIN, THAT HE MIGHT FISH. SOMETHING OF THE POETRY AND SENTIMENT THAT SURROUND THAT SPORT. THE RIVER AVON IN THE GOOD OLD DAYS. VERSES : LET ME WANDER BY THE AVON. 



\section{CHAPTER IV.}

On the Banks of the Aron

T NEVER see a small boy carrying a fishing pole but I feel like following him off to those marvellous places he knows, where the somnolent sucker, lively chub or shiner, or rock bass await the lure of the baited hook. My fishing preserve was the Classic Avon, the Canadian stream of that name, I mean, which, in the good old days, was, as I remember it, a clear, rippling little river. 'This was before it wore its strength out trying to force its way through the sewage that has been pouring into it. There were many good old swimmin' holes and quiet pools where fish abounded.

When I was a small boy I recall that the precentor at the village church, who long since joined the "choir invisible," on festive occasions used to sing that, to me, most beautiful of all Burns's songs, "Flow Gently, Sweet Afton." In my boyish fancy and childish innocence I imagined that he was singing about the Avon. The singer had a fine Doric accent so the error I fell into may be pardonable, and then I was in the juvenile class. I have loved the Avon ever since, but it was a far, far different stream then, than now. There was then a fringe 
of overhanging trees along its grassy banks and it had old swimmin' holes a-plenty, and many shady pools where the small boy loved to linger and dream and fish. The stream had then more water and there were not so many microbes or bacilli in it. In the spring-time the Avon did not roll her waters gently to the sea, but forwarded them in a mighty rush. When the rush was over and fences, and sometimes bridges, had been swept away that sweet river would babble sonnets all summer long. And, it may be remarked, that there is no sweeter melody in nature, to the ear properly attuned, than the chattering, babbling, rippling concord of sweet sounds from a running stream.

A small boy on the farm, in the days when the grain had to be bound into sheaves by hand, and when the Canada thistle flourished and made its presence felt in the harvest field, had to cut thistles amid the growing grain. He was given a spud, an instrument like a chisel with a long handle, and along about-well, knee-deep in June, as Whitcomb Riley, the poet, puts it-went np and down the ridges through the growing crops spearing thistles. Of course, he'd rather have been fishing but the fates were prominently arrayed against him. In these modern days with the selfbinding reaper, thistles are not looked upon as dangerous to the harvester, and beside, I am informed that their place has been taken largely by other weed pests that are really much more threatening to agricultural success. 
Of course, when it rained, no farmer would expect his young son to cut thistles with his trousers dripping wet and those were mostly the occasions when I fished. And how I used to pray for rain and whether the wind was in the right direction or not.

Perhaps you remember those beautiful lines of Wordsworth's, beginning:

"My heart leaps up when I behold

A rainbow in the sky."

Mine used to leap up skyhigh when I beheld a rain-cloud come swooping up from the west or any other point of the compass. It meant fishing. Can't explain just what there is about fishing that so affects the heart of a boy, but as I've already stated, to me it was the king of all juvenile sport. They say that mankind are all born gamblers and fishing may be classed as a gamble. With high hope you bait your hook and drop it into the likeliest place-you may or may not hook a fish but the sensations engendered are delicious.

"A schoolboy by the Avon sits, Old Sol's big face is warmly beaming, The boy he doesn't notice thisBut how his eye with hope is gleaming! He feels a tug upon his line And notes the tiny rippling billows, 
He gives a jerk and o'er his head, There goes a sucker 'mong the willows;

That's fishing."

\section{DOWN AROUND THE BIVER}

No doubt, dear reader, you have read and are familiar with those "Down the River" poems of that nearest-to-the-heart-of-a-boy, of all the versemakers, James Whitcomb Riley. If you haven't read those poems, better get busy. Life is brief and you might miss the opportunity. If you haven't time to read the lot let one in particular soak into your inner consciousness. It begins :

"Noon-time and June-time, down around the river!

Have to furse with Lizy-Ann but lawsy! I forgive her!

Drives me off the place an' says 'at all 't she's a-wishin'

Land $o^{\prime}$ gracious! time'll come I'll git enough $o^{\prime}$ fishin'!"

\section{YOUTHFUL FISHERMAN'S DREAM}

I remember one day when I'd had rare luck and had a dozen or more fine large chubs on my string, a full-grown fisherman with a classy fishing equipment happened along. But, alas, he had no fish! He eyed my string enviously and, reaching into his pocket, produced a half-dollar which he offered me for his choice of a dozen of my biggest.

I recall that my heart went all a-flutter for I had never before possessed, as my very own, that 


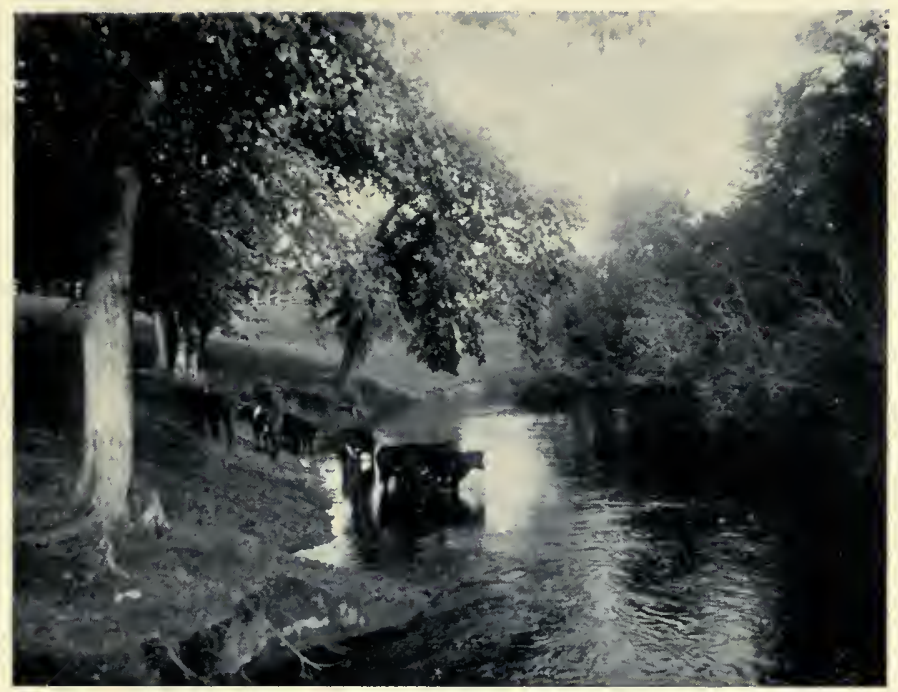

"A STREAM, WITH MANY A SHADY POOL, WHERE THE SMALL BOY LOVES TO LINGER AND DREAM AND FISH." 

amount of money. The exchange was quickly made and I felt that I was on the high road to fortune. I could discern vast possibilities in the sale of fish, but, alas, the best laid plans of boys, "gang aft agley." Opportunity never came knocking at my door in the form of half-dollars for a few chubs again.

\section{A FAVOURITE POOL}

On holidays small armies of boys used to wander along the banks of the Avon and, beside fishing, there were many baths taken. One favourite old swimmin' hole was known as "The Mudturtle." It was a fine pool, at a bend in the river, with shade trees on one side, and, in the centre of the stream, there was a large flat stone upon which, when the water was low, mud-turtles used to bask in the sun. Throwing stones at those turtles was one of the rare sports but I have no recollection that any youthful David ever hit one. I'd like to paint a word picture of all the beauty spots along that stream of my boyhood's dreams because, despite modern evidence to the contrary, in earlier days it was a beautiful little river. There were trees along its banks in many places, hawthorns, butternuts, and beeches and it wound about, in and out, through many attractive woodland ways. 


\section{THE CLASSIC AVONS}

The Avons of Old England-there are three rivers of that name in the Old Land-have been written about and, particularly, the Warwickshire Avon's beauties have been extolled. One of America's foremost painters, Edwin A. Abbey, who spent most of his life in England, painted the pictures for a handsome volume on this famous stream. I'm familiar with that book and its illustrations, but far, far dearer to me are memory's pictures of our own little Canadian Avon along the banks of which $I$ fondly lingered as a barefoot boy.

I have explored some of the small streams that empty into the Avon and have found the remains of beaver dams. I know of several still in woodland places where the hydraulic engineering work of the beaver may still be seen in outline-a rainbow shaped mound running across the watercourse. But:

"The beaver builds no longer by those streams,

But far away, in waters whose blue surface

Ne'er gave back the white man's face,

He rears his little Venice."

\section{LET THE BOYS FISH}

As I stated in the preface to this book, I did not set out with the intention of giving advice to the farming man. Might I be permitted for a mo- 
ment to recall that and appeal to, not advise, you Mr. Farmer-land o' goodness! if you've got a small boy about the place and be wants to go fishing, let him fish. If he's got a memory, and most folks have, when he gets to be a "greyhaired boy," the happiest recollection that he'll have will be of fishing days, and he will remember, too, the attitude that his father held about his desires in that regard. Pardon this personal reference but it's one of my kindliest recollections of my own father, that he never took a fishing pole out of my youthful hands.

It's the call of nature, you know, when a boy wants to go fishing. Harken to this:

Don't you hear the creek a-callin':

"Bring your bait an' fishin' pole,

Bass an' shiners jes' a-lollin'

In the deep an' shady hole."

Dad's a-yellin' from the stable, "Son, get out the team an' plough";

Ma's a-callin' 's loud she's able, "Jo, come quick an' milk the cow."

Stranger, supposin' we swapped places An' them three was callin', "Jo!" Don't you think you'd jump the traces, Grab yer fishin' pole an' go?

SMALL BOY DOESN'T TELL FISH STORIES

It is not the small boy, you know, who deals in fish stories. He is too intent on results to bother 
about such inconsequent affairs. He may, it is true, have a word to say about "the big one" that he hooked but got away, but it ends there. It's your grown-up fisherman who usually carries some "inspiration" with him that has not been dipped up from the rill, that deals in fishing "history." Fish stories would, therefore, be out of place here.

Never knew a small boy go off a-fishing who carried a lunch along. He would always be in such a hurry to get away that he'd forget all about such an unimportant thing as that. I was, in a way, one of the most fortunate of the juvenile disciples of the Immortal Izaak who roamed along the Avon in the good old days. My grandparents lived on the banks of that classic stream and, it usually happened, that I'd pull the latch-string at that hospitable old home at the right moment. I have on memory's films a picture of a kindly old lady who used to "stuff" a hungry young fisherman to his "tummy's" capacity.

\section{THE DEAR OLD DAYS}

Even if you have reached the age, dear reader, when the actual exertion of fishing would tire you, in the glorious month of May or June, in duty to yourself, you should let your mind drift back to those shady pools of boyhood's happy days. I don't know of any more loving retrospection when "care has cast her anchor in the harbour of a 


\section{On the Banks of the Avon}

dream," than to recall memories of fishing days.

All along that Avon stream there are gladsome pictures for me and I feel the thrill of youth return when I put those films on my memory machine.

Let me wander by the Avon, a barefoot boy ag'in, A-haulin' out the "shiners" with a little crooked pin, $\mathrm{An}^{\prime}$ ' see its wimpled waters twinkling onward to the sea, $\mathrm{An}^{\prime}$ in their merry gurgles hear its messages o' glee.

Let me go a-loiterin' 'long its banks 'at smelled so sweet, Where blue flags an' dandelions grew to tickle my bare feet,

$\mathrm{An}^{\prime}$ see the saucy kingfisher a-divin' from some tree; Let me hit the trail to boyhood an' be like I used to be.

Wish I could this minute with old Father Time play tag, I'd set out on that boyhood trail with steps 'at would not lag,

An' find my dear old mother standin' at the orchard gate,

Where she used to watch for me whenever I came late.

Wish I could peer beyond the blue o' heaven's starry skies.

Catch one of her old-time smiles, see the lovelight in her eyes-

'Twould smooth life's rougher places, help me break the bonds of sin-

Let me wander by the Avon, a barefoot boy ag'in. 



\section{CHAPTER V : RED LETTER DAYS}

BED LETTER DAYS OR EVENTS TO BE REMEMBERED IN THE LIFE OF $\triangle$ COUNTRY BOY, HIS FIRST CIRCUS DAY. LONG TROUSERS AND RED-TOPPED BOOTS. HIS FIRST DAY AT THE PLOUGH. SOME GREAT MEN WHO HAVE PLOUGHED. PLOUGHMEN WHO NEEDED FINGER-BOARD AND COMPASS. VERSES-DEACON JONES, PLOUGHMAN. 



\section{CHAPTER .V.}

\section{Red Letter Days}

R ED Letter Days or events to be remembered $\mathbf{R}$ in the life of the country boy of other days might be indexed thus:

His first "Circus Day."

When he first wore red-topped long boots.

When long trousers were first donned.

When he first went forth to plough alone.

This list is, of course, far from complete, but is sufficient for this occasion.

\section{FIRST "CIRCUS DAY"}

I shall never forget my first "Circus Day" for good and distinctly remembered reasons. I had only one eye to see the elephant, although, ordinarily, I am blessed with dual vision. That July morning my father was cutting grass with a scythe, from the corners of the old snake-fence that surrounded our hayfield. "The hired man who worked for pa" drove the mowing machine and I was engaged in the delectable and pleasurable effort of discovering young bob-o'-links in the clover and locating bumble-bees' nests in the fence-corners. There were many of these to be 
found in the good old days, and I had located a very thriving colony of wild bees that morning. A large, intelligent and quick-acting fussy bumblebee resented my intention of robbing its nest and punched a hole in my cheek adjacent to one of my eyes.

I was a round-faced, rosy-cheeked youngster in those days and you should have seen that cheek of mine an hour after that bumble-bee so effectively and emphatically sat down on it. One eye was closed and I was so lop-sided that I leaned over.

And that was Circus Day.

But I went just the same as if I had had two good eyes, and I recall that with the one I had I could see that the town youngsters eyed me with broad grins. In my innocence I supposed, of course, that the town folks would all know I'd been stung by a bumble-bee. I didn't know, at that time, just how ignorant townspeople are of what goes on in the country. Those folks all thought, of course, that I'd been fighting.

As I stood in front of the cage containing His Majesty, the Royal Bengal Tiger, I recall that a circus attendant shouted:

"Here, you boy with the lop-sided face, back up there or you'll frighten the animals." But he winked at me as he said it and I was sure that he knew how it had happened. 
COPPER-TOED TOP BOOTS AND LONG PANTS

Among my private treasures is a daguerreotype in a leather and gilt case. I'm in the picture and although under five years of age, I was wearing long pants, also my boots were red-topped and high, and had copper toes on them. The copper toes are visible in the picture and I've been told, by my mother, that I raised a "scene" in the photo gallery because I was made to pull my trousers out of my bootlegs, and so cover up those red tops. I cannot recall from memory's storehouse any incident or circumstance of boyhood's days down on the farm, when I had as great a glow of pleasure as when I donned those boots and long trousers.

\section{A FIRST DAF AT THE PLOUGH}

Ploughing on our farm was one of the exact arts. It had to be done well or somebody would lose his job, and I knew this as one sunny morning I was turned loose into and instructed to turn over the summer fallow of several acres. I had never set out alone to plough before but had been allowed to hold the plough a few rounds on occasion.

I felt I was one of the lords of creation that morning as I hitched my team to that most ancient of all the implements of earth and set forth to acquire knowledge in the art of turning fur- 
rows. I'd decided that I'd be a hero of the plough, that is, that I'd win prizes at the township, county and, perhaps, provincial ploughing matches.

\section{SOME GREAT MEN WHO PLOUGHED}

Right here let me set down a word about the plough, because to me it is at once the most necessary of all agricultural devices that God gave inspiration to the heart of man to devise. To be a first-class, skilled ploughman is to have reached the acme of usefulness - the high point of civilisation. Those chaps that brandish the sword, faugh! they wouldn't handle them long if there weren't a multitude with a grip on the plough handles. It is not definitely known who made the first plough but likely our Father Adam tickled Mother Earth with some sort of ploughing device, and all down through the ages it has held sway. And don't forget, please, that there have been some mighty big men in the world's affairs who ploughed.

There's Cincinnatus who left large and wellindented footprints on the pages of history, and after whom those pork-packing Americans named a big city; Oliver Cromwell gathered many of his cleverest lieutenants from the furrowed fields; Robert Burns ploughed, and sang as he ploughed, songs that go ringing and rippling adown the grooves of time; Abraham Lincoln, whose figure looms up on the horizon like a Colossus astride the world-mighty, big man Abe and he ploughed with 
an ox-team too; Oliver Wendell Holmes, poet, philosopher and man of letters, that any nation on earth would be proud of as a citizen, was in his youthful days a ploughman, and later was chairman of an Eastern States Ploughman's Association. And if there is a farmer reader who hasn't read his fine poem, "The Ploughman," I would say to such a one, better take an hour off and do so and offer your young sons a worthwhile premium to commit those lines to memory.

They are better and likely to be more effective than all the stay-on-the-farm addresses you'd hear in a quarter-century of Farmers' Institute sessions.

Let me present a few lines from that noble poem:

"Clear the brown path, to meet his colter's gleam! Lo! on he comes behind his smoking team, With toil's bright dewdrops on his sunburnt brow, The lord of earth, the hero of the plough! First in the field before the reddening sun, Last in the shadows when the day is done, Line after line, along the bursting sod Marks the broad acres where his feet have trod.

"O gracious mother, whose benignant breast Wakes us to life and lulls us all to rest; How thy sweet features, kind to every clime, Mock with their smile the wrinkled front of time! We stain thy flowers-they blossom o'er the dead; We rend thy bosom, and it gives us bread; 
$O$ 'er the red field that trampling strife has torn, Waves the green plumage of thy tasselled corn; Our maddening conflicts scar thy fairest plain, Still thy soft answer is the growing grain."

\section{POETRY VERSUS CORN CULTIVATION}

Mention of poetry in connection with farm life invites me to recall an incident at a rural home that I know well: They were sons of the soil, neighbours, and old, and that day had been attending a meeting of the Farmers' Parliament. Jo had invited his old friend Jim, to linger a while and take tea with him.

As they ate in the comfortable farmhouse dining-room they discussed the addresses they had listened to that afternoon.

"Did ye hear, Jo, what that chap said about farmers givin' more attention to poetry 'stead o' wearin' theirselves out cultivatin' corn an' other crops?" said the visitor.

"I did, Jim, an' I jest could hardly keep from interruptin' er laughin' out loud. Dinged nonsense, that's what it was. Think o' you an' me Jim, makin' up verses, as well as readin' 'em, for that's what he meant we should do."

"Ever try yer hand at rhymin', er verse-makin', Jo?"

"Not in recent years, Jim," replied the host with a furtive glance at his aged wife.

"But you did once, Grandpa," broke in the young granddaughter who often visited the old 
couple, "for Grandma showed them to me. She keeps them in the big Bible and all tied up with blue ribbons," continued the little girl, "and she said, too, they were just the nicest verses that anybody ever wrote."

"Now, now, Gracie, don't you say another word. I told you that was a secret, didn't I, and there you go telling," said the old lady with a look on her face which was not altogether one of displeasure.

"Oh, then you've tried yer hand at poetry, Jo," said the visitor, with a beaming face.

"Well, that was nigh half-a-century ago, Jim, an' ye see a fellow 'll do things when he's young that sort o' seems foolish later on. I did write some verses one spring 'way back, but I didn't know they'd be preserved an' rise up in judgment against me. That was the spring Mary an' me was married. She was kind o' literary an' I jest wanted to show her that I could spill out words that seemed rhymy-like. I'd most forgotten 'bout 'em."

"Grandma looks at them often yet and she can say them without looking," broke in the grandchild.

"It's well you didn't deny it, Joseph, because if you had, just as sure as sure, I'd fetched those lines of yours and had Gracie read them out," said the country belle of bygone years.

"Tut! Tut! Mother, I'm not denyin' 'em. Ain't forgot the occasion either 'at dragged 'em 
out $o^{\prime}$ me, but when that there chap down at the Institute meetin' started in tellin' us to cultivate poetry, 'stead o' corn an' turnips, it kind o' riled me," replied the old man in a mollifying tone.

"You ain't the only one in the neighbourhood that's been guilty o' writin' poetry," broke in his aged friend. "Why, jest the other day some o" my grandchildren was makin' limericks fer some newspaper prize an' they wanted me to help 'em. I don't know anythin' about limericks, but, maybe, I could make a rhyme, I says. An' I did, but I never got it finished. I started out somethin' like this :

"When I was young my ancient Dad Would cut for me a blue-beech gad, An' start me off to the bush-lot where The white-faced ox an' the brindled steer Was browsin' 'round-

an' there I stopped dead still. Couldn't lift my feet an inch further. Ye ought to be mighty glad, Jo, that yer wife's keepin' them verses 0' yours done up in tissue paper an' blue ribbons. There ain't anybody keepin' any o' my verses between the covers of the Good Book or anywheres else, an' lookin' at 'em often, an' learnin' 'em off. Ye see, I never got anythin' finished up right, an' poems that ain't finished is no more use'n a wheelbarrow 'thout a wheel."'

"Well, maybe, Jim, that Institute talker was right, after all, 'bout cultivatin' poetry," said the 
aged farmer with a smile in the direction of his wife. And then they changed the subject to a more prosaic theme.

\section{FURROWS CROOKED AS A COW PATH}

Of course I was not full of thoughts of the history of the plough and the sentiment which pertains to the art of turning furrows when I went forth that July morning to try conclusions with that summer fallow. I freely admit that my first furrows were irregular and somewhat resembled the old cow path that ran crooked to the wood. My plough bumped into many stones and it seemed to me that I was hit on both sides at once by those plough handles at times. The dew of duty - as the poet terms it-was on my brow. I was perspiring, yes, just plain sweating. It was a hot and dusty job but all my troubles vanished when along about the middle of the forenoon my father came to investigate, and informed me that, for a beginner, in the manly art of turning furrows, I was doing very well indeed.

At dinner that first day at the plough I found myself gripping my knife and fork as if I still had hold of the plough handles. I was terribly in earnest and I remember that I related to my mother my adventures in the broad field of agriculture with some pride.

"But you're not going to be a farmer, my son," she said with a kindly smile. You see my mother's 
ambition was that I should be a minister, and perhaps, she felt I was becoming too enamoured of the work of making parallel straight marks on the surface of the earth. I write "parallel" with fear and trembling. Some reader may have seen me plough at some time or other.

I recall, too, that during the afternoon I discussed with a neighbour, while leaning on the line fence, the most approved methods of disposing of Canada thistles and other pestiferous weeds. Getting along fast, wasn't I?

Yes, indeed, the day he goes forth to plough for the first time is the beginning of a new eraa momentous occasion-in the life of a farmer's son.

\section{CRITICISM OF MY PLOUGHING}

A young man accompanied by a sweet-looking maid, from a neighbouring town was driving along the highway past my field and he stopped to make inquiry as to the location of a certain farm. I overheard the pretty girl ask her companion, as they started off:

"What's that boy making marks on the ground for?"

Poor ignorant innocent! My ploughing referred to as "making marks." She wouldn't have known a plough from a sawlog and as for the art of turning furrows she had never heard of it. I was disgusted. 
PLOTJGHMEN WHO NEEDED FINGER-BOARD AND COMPASS

I knew a young Englishman in my homesteading days out West who always put up a stake at the end of his furrows. I asked him one day why he did this and he said it was to assist him in finding his way back to the place he started from. He was ploughing with oxen and on prairie that had some stones and wolf-willow roots. Looking at his work I did not wonder further about his using guiding stakes, because the ploughed ground looked as if an insane elephant had been rooting up the sod with its tusks. That ploughman couldn't tell whether he was going or comingthat's why he had a finger-board to show him the proper point of the compass to head for.

They used to tell a story out West about a young emigrant who was from a big city and who knew nothing about ploughing. They said he had a compass fastened to the beam of his breaking plough because when he started out with a furrow there was grave danger of his getting lost on the prairie. I don't present this as unadulterated truth but I've heard it told by those breezy, free and sometimes careless of fact, local history-makers on the plains.

\section{AN "ABE" LINCOLN STORY}

"Abe" Lincoln used to tell of an incident of his boyhood days about ploughing with oxen. He and 
his brother were at work, "Abe" driving and his brother holding the plough, and the future Great President wanted to change jobs and hold the plough, but his brother objected. The "critters" were slow and lazy when all at once to the surprise of the lads the team started off at an amazing pace. Even "Abe" with his long legs could scarcely keep up with the procession. When the end of the furrow was reached "Abe" discovered the cause of the swift movement. Several "bulldog" flies had settled on the back of the team and were punching holes and pumping up blood as only bulldog flies can. The youthful driver being handy with his whip picked off the flies.

"And that brother of mine," said "Abe," "was just as mad as a wet hen."

" 'What did you go and do that for,' said my brother, 'don't you know that those flies were what made those oxen travel?'

" 'Yes,' I replied, 'but if these critters are going to travel like that I've got to hold at least one of those plough handles.' ",

You see even as a boy "Abe" wanted to be at the helm.

\section{DEACON JONES, PLOUGHMAN!}

As a conclusion to this sermonette on ploughing and as a "lastly brethren" argument, here are some verses, and the obliging reader will please sing the second and sixth stanzas: 


\section{Red Letter Days}

Adown the field marched Deacon Jones, And as his plough the furrow turned, $\mathrm{He}$ warbled in his loudest tones

A hymn that he had long since learned.

"Uh, lasss'n did my Sa-vyer blee-

Dand id my suv-ren di-ee

Woo de devote that sacred $h$ -

- - - -nation!"

The lordly robin in the tree

Cut short his song in trembling fear, Such language scared the busy bee, That buzzed among the clover near.

The plough had hit a hidden root, The handles banged Jones in the side, He let loose swear words by the foot And cultured manners cast aside.

But now again our old friend Jones Steps blithely on, his voice a-ringing; His plough strikes hard some hidden stones And stays the hymn he's gaily singing.

"Wah zit fur crimes tha ti have done, He groaned upon that tree-ee Um-ma-zing pit-tee gra-sain-none, And live beyond - - -"

The catbird yells in sheer delight, The red squirrel up the beech-tree scrambles, By Jones's language sent to flight The "cotton-tail" hides in the brambles. 
Yes, all along our life's pathway

Sin lurks like stones beneath the sod

To try our faith. Ah, oft we stray

Far from the way that leads to God.

So sang Old Jones and so do we

Go singing o'er life's pleasant meadows, While going's good, we, same as he, Look skyward, far above the shadows.

But when our painful trials come, Like Jones, we fall, and raise a rumpus, And roar and rave and make things hum Whenever life's plough handles thump us. 


\section{CHAPTER VI: DAIRYING IN THE OLDEN DAYS}

THE DAIRYING INDUSTRY AS CONDUCTED BY THE PIONEER. WHEN THE DAIRYMAID USED HER FINGER AS A THERMOMETER AND LICKED THE CREAM OFF IT. DOG CHURNS. USED A SKIM-MILK CHEESE FOR A GRINDSTONE. PIONEER'S CHEESE-PRESS. A CHURNING ACCIDENT. 



\section{CHAPTER VI}

\section{Dairying in the Olden Days}

WHAT interesting as well as appetising reading it would make if one could write a full and complete history of the dairying industry since the first real, or pretended pat of butter was made. Who did the first churning? Now, there's a mystery that affords food for reflection.

Did Adam have a milkhouse on the banks of the Euphrates in the long ago, and was Eve the first dairymaid? Sacrilegious to ask such a question! Not a bit of it. Why, they are never done digging and delving in those Eastern countries, just to find answers to all sorts of inquisitive queries about the past.

I am not aware that any of those learned armchair "dairyists" (this is a new word, handpicked, recently), have ever given out anything about dairying in the ages of long ago, but as I have already remarked, it would be interesting to know who made the first print of "condensed sunshine" and fashioned the first chunk of compressed curds.

The remark is attributed to Solomon, "Of the making of books there is no end." He might have used the same statement regarding butter, because 
there were butter-makers in his day, perhaps long before. In the Psalms we find this, "The words of his mouth were smoother than butter, but war was in his heart." And in the Book of Judges a verse reads: "She brought forth butter in a lordly dish."

\section{BUTTER DATES FROM 'WAY BACK}

There is no doubt, therefore, as to the antiquity of this form of food but one can only conjecture and speculate regarding the manner of its production. The wonderful advancement that has taken place in recent years in matters pertaining to dairying is almost marvellous. The application of science to industry is not more marked in any of the thousand and one activities of mankind. Judge Haliburton in "Sam Slick," makes this remark, "All the metaphysics in the world would not make a pound of butter." He meant, of course, that somebody had to do some physical work, including churning, before butter might be produced. But the investigations of the scientists have helped a whole lot to make the production of butter and cheese a much easier job than it was even a quarter of a century ago.

Now what has all this to do with "Old Days on the Farm," you ask. Well, to be candid, I am just trying to lead up to the butter-making methods of the pioneer. In a former chapter I have tried to show what an important animal Old Bossy is in our civilisation. Next after his old ox-team, 
the early settler got him a cow. And after he built his cabin and a shelter for his oxen and cow, his next thought, in the architectural line, was a milkhouse. If there was a knoll near his home in the woods, he'd make a "dug-out" milkhouse, with a superstructure of logs. In these milkhouses our first dairying was done and an industry begun which has made the name of Canada famous wherever the flag flies and wherever they spread butter on the staff of life. The milkhouse would have crude shelves about its wooden walls, a gravel floor and, sometimes, a spring of water in it. Millions of pounds of hand-made "condensed sunshine" were produced from these rude dairies of the pioneers, and most of it was prime stuff, too. Cake and pie and bread and coffee, like mother used to make, are appealing, of course, but every man or woman raised on an old-time farm, is ready to vote that his or her mother made the best butter to be had on earth. The first milkpans of the pioneer were wooden-I am informed-something like the modern wooden butter-bowl, and were made by the Indian or squaw, in fact, they were termed squaw dishes. Then came the Delft or earthenware dishes which, later, gave place to the tin-pan of modern commerce.

\section{THE FIRST CHURNS}

The first churns were wooden, surely, with the up and down dasher, and the manipulation of a 
churn full of heavy cream was considered an effective way to develop the biceps muscles of the operator, more particularly if the butter was contrary and wouldn't "come" in a reasonable time. I've known churnings to take a half-day and then everybody would be warm and excited about the milkhouse. Thermometers were not hanging on the walls of the dairy then and the temperature of the cream was taken, probably, by dipping into it with the index finger of the right hand or left hand if the dairymaid were ambidextrous.

As a boy I churned and I recall that the lid of the churn was often raised that I might take a peek in to see if the cream had "broken." The "broken" stage was the condition reached just before the butter had "come." I recall, too, that, to encourage me, my mother would pour in a limited quantity of warm water to get the temperature just right, I presume. What a sigh of relief we youngsters would yield up when the separation process developed. I mean, of course, not only when the butter became separated from the buttermilk, but also when we could separate ourselves from the handle of the churn. I've known fellows who were so fond of buttermilk that they'd gladly churn just to get a "fill-up" on that liquid beverage, but I was never such an enthusiastic buttermilk-bibber that I'd find myself drawn toward dairying pursuits in order to gratify my appetite-particularly by buttermilk. With the 


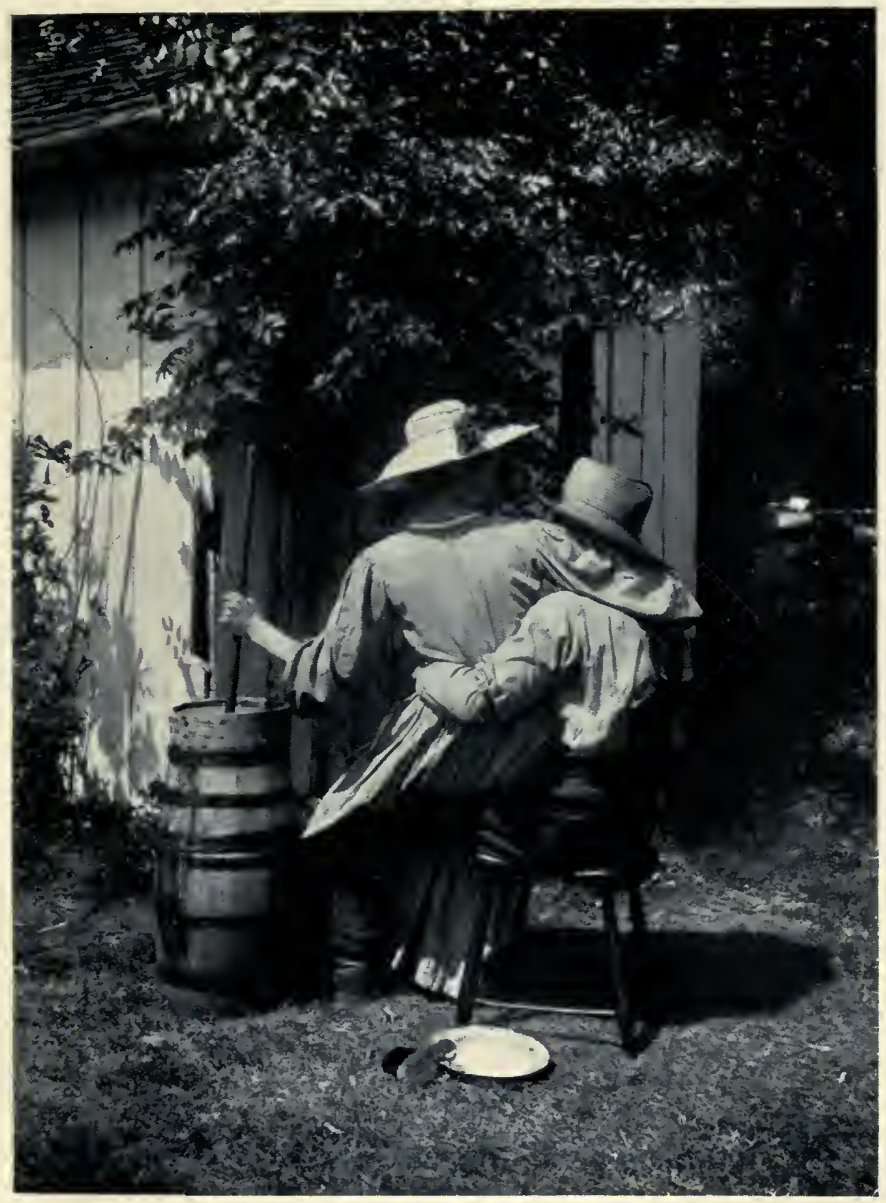

"BY THE VINE-CLAD DAIRY DOOR." 

advent of the revolving or barrel churn a mighty load was lifted from the spinal column of the pioneer dairymaids and dairymen.

\section{DATRYMAID LICKED HER FINGER}

But to return a moment to the milkhouse: the milk would be spread out in shallow pans that the cream might rise-there's a scientific reason why cream rises to the top, but, please let me off. I only know it does and besides, natural science was not on the bill-of-fare when I feasted at the round table of knowledge. I asked a farmer the question once, in my tender years, and he said the best always comes to the top like big berries in a box or big apples in a bag. That's the way he sidestepped and I have to pass on this cream-rising query, too.

Well, after the cream had risen and formed a leathery bridge across the top of the pans, so the flies and spiders and other adventurers might not fall into the milk and perish, the dainty dairymaid would run an index finger around the edge of the pan to loosen the cream. If she was a dairymaid with a normal appetite she'd lick her finger and then proceed to skim the milk with a tin skimmer. The cream would be allowed to ripen for two or three days in a stone crock before being churned. 


\section{BUTTER LIKE MOTHER USED TO MAKE}

You needn't tell me, you modern up-to-the-minute creamery men, with all your tubes and testers and scientific equipment, that you can produce more tasteful and appetising butter than the dairymaid of olden days, even if she did lick her finger and use it as a thermometer. I've eaten her butter and yours, hers first, and I just will not go back on my first love.

Time was when it was the laudable ambition of most every woman on the farm to be the champion butter-maker of the community. And what rivalry developed along about Fall Fair time in the good old days. There used to be dozens of contestants in the home-made butter section at exhibitions of farm products. And those fine pioneer women housekeepers made cheese as well as butter, and good cheese, too. I've eaten it and, when one eats a thing and likes it, and lives long and happily afterwards, he'd be an ingrate, indeed, if he did not cherish such a recollection in memory's storehouse.

\section{A WORD ON SKIM-MILK CHEESE}

I am referring, however, to new-milk cheese. Why, is there any other kind, you ask. Well, there used to be such a thing as skim-milk cheese, but I feel that I am right in stating that it is now entirely off the market. 
I heard this story about a farmer in 'way back times, whose wife made skim-milk cheese. He was too poor to buy a grindstone so he mortised a hole in one of these cheeses, put in a wooden shaft, attached a crank, and so overcame the difficulty. Those skim-milk cheeses were, when aged, about as tough, indestructible and indigestible compositions as were ever compounded by the hand of man or woman.

\section{DOG CHURNS}

I omitted to state in connection with the churning part of the dairy business, that some of the more ingenious and inventive pioneers rigged up dog churns-a form of treadmill. I know at least half a dozen farms where dog-churning outfits may be seen, but these are not now in use. Large collies or Newfoundland dogs were the favourite breeds for such work and I am informed that it was not unusual that the dog had to be searched for on churning day. The canine could tell by the movement about the dairy or milkhouse when a lard-work sentence was about due and would crawl under the barn or hide in the shrubbery. I've known, too, of small boys who absented themselves from home on churning days.

\section{OXEN WISE, TOO}

I recall that a yoke of oxen I possessed in my homesteading days out West showed "wisdom," too, in avoiding hard work. At noon when plough- 
ing, I'd turn them loose to graze about the prairie bluffs. Sometimes the team would be difficult to find when the time came to resume work. I used to attach a bell to the neck of one of my horned "critters." After feeding for a time they'd search out some secluded place in the long grass, or in a chump of willows, and remain absolutely motionless, so not the faintest tinkle of the bell would be made. They'd endure the torments of "bulldog" flies and mosquitoes rather than betray their hiding-place. And yet some folks use this expression, "the stolid ox." "The thoughtful ox" sounds truer to me.

WHEN THE BUTTER WOULDN'T "COME"

Now, what does a man know about butter-making or butter, I hear some former dairymaid say. All he knows is that it's to be spread on bread. But stay, that's not so in the case of some men and your humble servant is one of these. I kept "bach" out West when it was referred to as "wild and woolly," milked the gentle cow, skimmed the cream, churned the churn and spanked the butter. There now, haven't I a right to tell what I know about dairying?

Josh Billings raised a hill of cucumbers and corn in his back yard and then wrote a book on what he knew about farming; Bill Nye helped herd the potato-bug off the family patch when a boy, and, later, delivered lectures on "My Experiences 
as an Agriculturist"; should I be called on to show reasons why I make free on paper with the cow with the crumpled horn and the dairymaid of other days?

I remember in my dairying days out West I once churned four hours (sun-time) and the butter wouldn't come. I danced jig-time, waltzes, polkas and all the other steps I knew with that dashed old churn, I made poetry while I churned, talked kindly and, sometimes, unkindly, and yet that butter-fat remained obdurate. At length when the hope that is said to spring eternal within the human breast had entirely fled and also when hope deferred had made my heart sick, I upset a kettle of boiling water into the heartless thing and lived on scalded cream for two days after. My partner on the ranch who came in just as the climax had been reached, remarked that it was difficult to churn ice cream into butter. You see, it was in winter-forty below zero weather-and the cream had too much ice in it. If I'd had a sensitive thermometer finger like the old-time butter-maker I'd have warmed up the cream-crock before dumping its contents into the churn. But I learned in the school of experience that it's really impossible to make butter from iced cream.

\section{PIONEER CHEESE-PRESS}

Yes, indeed, the churn and the cheese-press of the pioneer are worthy of a place in this "Old 
Days on the Farm" chronicle, and my regret is that I am not sufficiently informed regarding them, to pay the proper tribute due. I recall that my mother used to make cheese and that the means of squeezing the curds into shape was with a long board as a lever with a stone on the end. To get more or less pressure the stone would be moved farther from or closer to the "chessel." That is what my mother called the mould or wooden receptacle in which the cheese was made. I have never heard the word since boyhood days and I had thought it was one that the Scottish folk had made and copyrighted for themselves, but not so. That book of words, great and small-the dictionaryhas it.

Later, a small screw press was used, the forerunner of the kind used in large cheese factories.

\section{A CHURNING "ACCIDENT"}

I remember a square or box churn in which a dasher was operated by turning a crank. There was one at my home and when in use it stood on two kitchen chairs. I have not forgotten that, on one occasion, when I should have been churning that I was playing tag instead, and accidentally removed one of the chairs. The result was that the churn upset, the lid opened and a gallon or two of cream spread over the kitchen floor. Doubtless the domestic felicities of the household were somewhat awry for several minutes afterward and I 


\section{Dairying in the Olden Days}

have no doubt either but that the incident closed by my mother saying, "Well, what's the use of crying over spilt milk." You see, she was Scotch and those folk nearly all have a way of consoling themselves and others by quoting a "saying" or a text, and, it may be added, that's the finest philosophy to be found in all the wide world. 



\section{CHAPTER VII: STUMPS AND SNAKE- FENCES}

WHEN THE FARM HAD SNAKE-FENCES AND STUMPG. THE HAYFIELD OF OTHER DAYS WITH ITS AROMATIC ODOURS AND BUMBLE-BEES. A NON-POETICAL SCOTTISH CANUCK. THE OLD-TIME HARVEST FIELD AND THE REAPERS OF THE PIONEERS. A PIONEER'S "CRADLING" STORY. 



\section{CHAPTER VII}

\section{Stumps and Snake-Fences}

$\mathrm{N}$ this chapter I propose to tell something of 1 the farm of earlier days-not the bush farm, but shortly afterward, when it was bounded with rail-fences and had some stumps on it in the back fields. The V-drag and the old ox-team had almost vanished in my youthful days but, I remember the former was still on the premises. I am not giving up my claim, however, to having a knowledge of the ox. It happened thus: My father bought a farm adjoining our homestead and on this was an old beaver meadow of some thirty or forty acres. This meadow had growing on it clumps of willows, of several varieties, and he secured a yoke of oxen to remove these. With a log-chain and that yoke of oxen those acres of willows were rudely torn from the soil and hauled into heaps and burned. Through the centre of that beaver meadow a creek meandered with many a curve and there were muskrats and mink innumerable along that stream.

The meadow was alive with song-birds and there were also partridge and rabbits in numbers. In a pond formed by one of several beaver dams and fringed with willows, wild-ducks made their home. There were not so many hunters about in those 
days or that game preserve would not have existed long.

\section{THE OLD RAIL-FENCE}

In almost every fence-corner on the old-time farm there were weeds and wild flowers and innumerable places that were suitable for the nesting of birds. The passing of the old rail-fence and substitution of barbed or other wire has changed all that.

Many born-on-the-farm rhymsters have paid tribute to the old rail-fence of pioneer days.

In the happy days of childhood when we never knew a care

Greater than sore throat or measles or how mother cut our hair,

When a swollen eye from bee-sting and a stone-bruise on the heel

Filled our chums with envious feelings which they could not conceal,

On the farm were many treasures-things that we boys held most dear,

Meadows, orchards, creek, and woodland and the spring that flowed so clear;

And about them all, a wooden wall, where flowers and weeds grew dense,

Stood the pioneer's rough palisade, the homely old railfence.

Upon its rails the robin built its nest in early spring, Perched upon its stakes and corners the meadow birds would sing, 
Squirrels and chipmunks had a racetrack up and down its devious length,

And while it was not handsome, it sure was a thing of strength;

Wild bees with their honeyed treasure hived about its sheltering base,

To it rabbits fled for safety when the dog was in full chase,

And the "yellow jacket" often built its grey paper residence

In the nooks and hidden corners of the old rail-fence.

But now the old rail-fence curves around no more about the tidy blossoming farms by the banks of the Thames or classic Avon or other Old Ontario stream. It served its time and its time was the wooden age in this fair Dominion. I've been told that there were farms in Western Ontario fenced with walnut rails and I have seen some that were fenced with fine oak, maple, hickory, rock elm and other valuable timber. It has been charged, too, that our pioneers were wood butchers-that they had absolutely no respect or reverence for a tree, however magnificently proportioned. Ah, well, it was different in pioneer days and those early settlers had not much time to be sentimental-the bigger their clearings the more their young families had of the necessaries of life.

I have in mind one tree-a magnificent elmthat was spared by the woodman. It stands fairly in the centre of a main travelled public highway 
in a Western Ontario county and near a young city. It is regarded as a landmark by the country folk about and vandal hands are forbidden to bring about its fall.

I asked a man who lived nearby the "Big Elm" why the tree had not been cut down along with the other forest monarchs on the road allowance.

"Well,", he replied, "I've heard it said that in lumber-wagon and ox-team days when any of the old boys got 'feelin' good' in town, that when the hubs of their wagons hit the side of that tree they knew they were getting close to home. Then they'd straighten up and look serious. Maybe that's why they left the tree stand and maybe, too," he added, with a smile, "whoever started the story was just putting one over on the old boys. But you can see a lot of scars on that tree where the wagon hubs hit it."

I carried the inquiry further. I asked a Canadian of English descent about that tree.

"Why did they leave that big elm? Well, that's easy," he replied. "You see there was a big lot of Scotch here 'way back in early times, and those folks just had to have something to rub against. You've heard about those scratching-posts they had in some parts of Scotland. Between you and me," he said, in a lower voice and with a wink, "that's what they left that big tree for. Handy it was, you know, when they were walking. Of course they don't any of them use it now," he 
said, apologetically, "but away back-well, you know, they came from Scotland."

Dr. T. S. Sparks, a Canadian verse-writer of more than local fame, made the "Big Elm" the theme of some verses, and, quite recently, the picture of this lordly tree adorned the cover of a well-known American magazine. From Dr. Sparks's poem, "The Wayside Elm," the following verses are quoted:

Alone by the side of the dusty road Where the myriad feet of men have trode, Looming aloft in the azure sky Like some giant link of the ages by, No lordly mate of the wildwood near, Lofty-and lonely without a peerCatching the glance of the far-off eyeWinning the homage of passer-byTowering aloft with a royal grace, The lordliest one of thy lordly raceKing of the wayside path art thou, $\mathrm{O}$ giant elm of the lofty bough!

And alone by the wayside, firm and fast, I watch and wait while the years roll past,With my proud boughs spread to the wind-swept sky

I have mocked while a hundred blasts swept by,And the bolts of Heaven, from the tempest sped, Have forborne to smile at my kingly head.

Never a touch of joy or woe

In your hearths or homes that I did not know,From the joyous look and the voice of mirth, That greeted ye first in your hour of birth, 
To the sable car and the measured tread

Of the men who walked by your coffined dead.

I saw your grand-sires when they played In schoolday glee underneath my shade, I saw them grown to manhood's day, I saw them bowed-with their hair grown grey,

I saw them laid in their graves away;And as I saw your grand-sires once, I have seen your sires, I will see your sons. Alone in the world of the living $I$ Seem touched by the hand of eternity. A prophet voice to the future years From the past with its buried joys and tears! The countless seasons come and go, And the summer sun and the winter snow Have beat on my giant trunk in vain. They came-they vanished-but I remain.

\section{THE HAYFIELD OF OTHER DAYS}

You may talk about pastures green, far-off fields, baseball fields, fields of high endeavour, or any other enclosure that may be termed a field, but you cannot beat, in attractiveness, the old hayfield. I mean, of course, that one of other days with the snake-fence about it, and some stumps here and there and, perhaps, a few trees that were overlooked by the wood butcher. There was clover three feet long, timothy four feet high and a bumble-bee on every other head of clover. The surface was rough and it had to be mowed with a scythe for the reason that there were no mowing machines. 
I love to recall memory's picture of three or four strong men with scythes amputating grass and stirring up bumble-bees at every swish. There is no smell, lotus flowers from the Old Nile, attar of roses from Ispahan, or any decoction of sweet perfumes that those chaps who deal in herbs can stir up, that equals the aroma that came from an old-time hayfield. Likely the scythes shook it loose more than the mowing machine does.

I wasn't old enough to swing a scythe with effect but I used to carry water in a cool grey jug with clover leaves clinging to its sweating sides and I wish to remark that there were other things beside that grey jug sweating in the hayfield. Those sturdy scythe-swingers did perspire at their work and occasionally they would stir up a bees' nest on the sod or a colony of yellow-jackets about a stump.

An old-time hayfield is, indeed, a theme to grow poetical and sentimental about. But, alas, the rattle of the mowing machine and the automatic action of the side delivery rake and hay-loading outfit has side-tracked the poet and the painter.

\section{A NON-POETICAL OLD FARMER}

Just the other day I talked to a grizzled Scottish Canuck in poetic vein about the hayfield of the pioneer and he came back at me thus:

"Ay, mon, but you're very glib wi' the bonny words but, might I ask, did ever ye swing a scythe 
or rake hay in a stumpy field wi' an old-fashioned hand-rake. If ye had I'm thinkin' ye'd call the poet a leein' wretch an' the painter a barn fule for fleein' into raptures about makin' hay."

"But surely," said I, "you have not entirely put out of your memory the sound of the singing scythe as it made musical rhythm in the blooming clover, the joyous song of that blathering, breezy blatherskite, the boisterous bob-o'-link, and the merry laughter of the sun-browned lads and lasses who sometimes tossed and raked the hay."

"Ay, mon," said he, "but I could show you the other side o' the picture. You see, you chaps that never grippet the han'les o' a scythe and swished an' swished an' swished a' day, an' broiled, an' sweated an' ached, are no qualified to give a proper opeenion on the subject. 'Singin' 0 ' the scythe,' 'musical rhythm,' nicely worded phrases they are, but the man that handled the scythe never made them up. They came fra' the chap that maybe carried water and then sat down under the tree and watched the clover an' the sweat fall."

He had me coming and going but in defiance of his cold, hard-hearted presentation of facts, I want to go on thinking of that old-time hayfield from the sentimental point of view.

Fifty years ago when a farmer would decide on cutting his hay he'd say: "Boys, get those scythes down from the granary and bring them and a 
pail of water over to the grindstone behind the milkhouse. We'll start into that clover to-morrow."

To-day he says: "Jim, run the mowing machine out of the shed and get it oiled up. I think we'll take a few turns about that hayfield to-morrow. You'll drive the mower, Tom will run the tedder and your mother and I will go over and spend the day at Uncle Joe's."

THE OLD-TIME HARVEST FIELD

And there's the harvest field of other daysanother poetical spot, surely. To have seen several lusty men laying low the golden grain with their swinging cradles was a sight to be remembered. I've made sheaves behind a cradler and I once cut two acres of grain with that old-fashioned reaping tool-perhaps I'm qualified to write about the old-time harvest field. It required a man who was a direct descendant of Anak-a strong man mentioned in the Good Book, you know-to cut five acres of grain in a day, and he wouldn't feel like going to a moving picture show when the sun went down.

What a picture that ten-acre wheat-field makes in the August sunshine, gently undulating in golden billows, set in motion by summer zephyrs. Farmer Brown is proud of it, and, with reason. It represents honest toil and the staff of lifethe world's bread-and no defence is needed be- 
fore the court of posterity or any other court for any wealth acquired from it.

It's honest money gotten thataway.

To-morrow the farmer and his two stalwart sons will harvest that field of wheat. The blades of their "grapevines," "turkey wings" or "muleys," - these were some of the names applied to the different makes of grain cradles of other days,- have been ground to razor keenness on the old grindstone in the shed.

They have to wait an hour or two in the morning for the dew to clear away. They whet their shining blades, those brawny three, and with breasts bared and shirt-sleeves rolled up to shoulders, advance to the charge.

The swish, swish, swish of severing seythes resounds; this, and the rhythmical tinkling of the shorn stems against the cradle blades, is the deathsong of the wheat.

Those three mighty reapers sway from side to side with steady swing across the field leaving three ribbons of yellow-three well-butted swaths behind.

A few years ago that field was a forest and there are still some stumps as evidence of the mightier growth that fell before the woodman's axe. The ground is uneven, full of "cradle knolls," as the pioneer termed the hillocks left by overturned tree-stumps. It is rough going, but, that dauntless three, in slant array, like wild geese or ducks a-flying, swing and sweep through 
cereal glades until the long day's task is done and that ten acres of wheat is laid low.

The binding and shocking is a task for the morrow.

Warm work, that cradle swinging-well, I guess yes. Many visits were made that day to the cool grey jug in the hollow stump. A man didn't have to go "east of Suez," as Kipling says, to raise a thirst in cradling days. Let him swing a big, heavy cradle all day long, over uneven ground, and with snags, and snakes, and stones, and stumps, hidden in the grain and he'd have a thirst that would need a whole lot of liquid to quench. In shilling-a-gallon whiskey days they say it was not considered improper for cradlers to take a stone jug to the field, which jug did not contain water. And I've heard stories that cradlers had to be steadied by a man holding them from behind until they'd get the proper swing on. When they'd get rightly under way they could maintain a balance and win through with their swaths.

\section{THE REAPERS OF THE PIONEERS}

I well remember our first machine reaper-a big clumsy contraption with a reel to throw the grain onto a platform. It took two men and a team to work it. One man drove and another swept the grain off the shelf or platform when enough had accumulated to make a sheaf. I recall 
that there was a projection or shelf at the rear of the platform, and on this, as a small boy, I used to ride and let my bare feet trail among and be tickled by the stubbles. Despite the weight of that reaper and that the ground was rough and grain crops heavy, I was permitted to ride by my indulgent father.

Then came the self-raking reaper and it was thought that the acme of perfection had been reached in harvesting machinery. The binding had still to be done by hand. It could never be that any mechanical contrivance might be invented that would make bands of straw and tie sheaves. We never thought of twine being used for such a purpose and, if we had, it's likely we'd have felt that there was not enough string in the wide world for such uses. In those days twine for fishing lines was, on occasion, difficult to get. But inventive ingenuity and the march of progress solved the problem. Now the self-binding reaper holds sway.

\section{A PIONEER'S "CRADLING" STORY}

I once listened to a grizzled pioneer as he told this story of a "cradling" contest in which he was one of the chief actors:

"Away back in the sixties I cut many a wide swath in wheat-fields encircled by 'the old railfence' an' that's what I mean to tell ye about. I've got in mind a little contest I once had with a chap 
who thought he could swing a cradle a little better'n most folks, an' about that time I was luggin' around a purty hefty opinion o' myself in the same line. $O^{\prime}$ course us two had to get together.

"Fields were full o' cradle knolls then an' a fair sprinklin' o' stumps an' to cradle all day through heavy wheat was a job fer giants. But, o' course, there were giants-fer strength I mean -in those days.

"After preliminaries had all been settled, we were turned loose into a ten-acre wheat-field. A swath was cut through the middle an' the master o' ceremonies says, 'There, Jo, that's yours; an' Jim you'll take that chunk,' pointing to the north half of the field, 'an' swing, ye boys, swing, fer all that's in ye.'

"He didn't need to have said that last, fer Jim an' me, before he had got the words out, were at it, cutting an' slashin' like the Old Guard at Waterloo.

"The way we went up an' down that field that swelterin' hot August day would make yer Marathon road racers lay down and pant. We kept pretty close, swath after swath. Jim had a little longer reach than me, an' sometimes got to the end of his swath a few yards ahead, bat I had a side swing an' figured on nippin' off about six or eight inches more in width. I knew if I could keep near in the procession that Jim would have a swath or two left over at the end. But things 
don't always go jest as ye figure. As Bobbie Burns puts it-

\author{
"The best laid plans o" \\ mice an' men \\ Gang aft a-gley."
}

"The handle o' my cradle played dirl against a rotten stump when out swarmed a hive o' the liveliest bumble-bees that ever gathered honey. I got off with a few stings, but before the pesky things quieted down so I could work, Jim was half the length of the field ahead.

"Bees er hornets, er yellow-jackets fer Jim, is the only thing that'll save me, says I to myself. But no such luck.

"By noon Jim was a clean swath ahead an' it looked as if he had a sure thing.

"Hot, well I guess so. Woods on two sides o' the field an' not a breath of wind stirrin'. We were both as wet as if we'd been doused in the creek. By arrangement we'd to take a clear hour at noon an' we sat under a tree eatin' an' restin' an' sizin' up each other.

" 'Purty nigh all in, are ye?' says Jim as I stretched out like a lazy schoolboy under a tree an' closed my eyes.

“ 'Oh, don't worry,' says I. 'I'll waken up on time.'

"At one o'clock we started in an' I went out to the battle in my stockin' feet. I had on a pair o' long boots-I was always fond $o^{\prime}$ top boots ever 
sence my father had togged me out in red-topped ones when a youngster. My heels were blistered and that's why I left the boots under the tree, an' besides I'd been sweatin' so it was like walkin' with boots full o' water.

" $A n$ ' the leavin' off $o$ ' them there toppers nearly put me out $o$ ' the race. Anybody that's ever cradled knows how a fellow will gather up a lot o' stragglin' straws about his ankles because a man doesn't step high at that job. Well on one trip across the field I felt as if I had a whole sheaf draggin' at each heel. I'd give a kick out behind once in a while and try to shake the straw off, but the blamed stuff wouldn't seem to let loose. Then I stopped an' reached down an' give the stuff a pull an', what do you think? There fastened to each heel o' my socks was a big reptile of a snake three or four feet long. Each o' them had his hooked fangs fastened into the heels o' my thick woolen stockings. They'd got a holt and couldn't let go if they'd wanted to, I suppose.

"It was on the Huron Road we were at work, an' the boys said afterwards, that they could hear the yell I let out clear over at the village, a mile an' a half away.

"'Of all creepin' and crawlin' things snakes was what I feared most an' there I was hitched onto two o' 'em. Wasn't much wonder, was it, that I cut up some. Just went tearin' around that field like a steer in a corn patch with a collie dog after it an' I was yellin' at every jump an' them two 
reptiles jest hung on like a catamount to a deer. "Jim dropped his cradle an' came over on the run an' all the fellows a-watchin' the contest came too. They thought I'd gone suddenly crazy.

" 'Take his cradle away out of reach,' shouted one o' the boys, 'or somebody'll get hurt.' Then seven or eight $o^{\prime}$ them closed in on me an' in a second there was two dead snakes.

" "Hurt, are ye, Jo?" asked one of the boys. After I'd told them I was only scairt the bunch laughed till I thought somebody would bust.

"But I really believe them two snakes did the trick fer me. I was mad-mad at the snakes, mad at myself for makin' such a show, an' some mad, too, at the boys for that side-splittin' laughin'.

"I tuck up that cradle an' before Jim could gather himself together almost made up his lead an' - well, to make it short, I trimmed him by a swath in spite o' bumble-bees an' snakes.

"Five acres in ten hours was allowed to be a pretty fair day's work them days," said oldTimer as he. struck a match and started in to cloud the atmosphere.

"You haven't said anything about the brown jug hid under the sheaf or how much water you drank that day," I remarked.

"Well, I've always held that there are some things better not mentioned together an' to name brown jugs an' snakes in the same story might start folks talkin'," replied the old man with a look that meant a whole lot. 


\section{CHAPTER VIII: A SHOOTING MATCH}

WILD GAME ON THE OLD-TIME FARM. A "SHOOTING MATCH" SUPPER AND DANCE. WHEN EVERYBODY DANCED AND THE DANCES ALL HAD CORNERS ON 'EM. A DANCE "HOLD-UP." THE FIRST ORGAN IN THE NEIGHBOURHOOD AND SUNDAY IN THE OLD FARM PARLOUR. 



\section{CHAPTER VIII}

\section{A Shooting Match}

$A^{\text {MONG my memories of boyhood's days on the }}$ A farm are pigeon-holed away many stories by mighty hunters I have known, pure fiction, mostly, I presume, and I recall that I used to draw closer to the kitchen stove as I listened to pioneers tell thrilling stories of wolves, b'ar, catamounts and other wild and ferocious beasts that roamed loose in this domain when our part of the world was young.

B'ars and wolves had all departed from about the banks of Avon and Thames long before my day, but I was in at the killing or, at least, I saw the last deer and wildeat shot or captured in my native township.

My way to the schoolhouse on the banks of Avon, where my young ideas were encouraged to expand, lay through a small cedar swamp and, in this swamp, I remember, a neighbour had set traps for mink and captured a wildcat. He brought his prize over to our house to exhibit it and I peered at it from behind my mother's skirts. Ever after, in passing through that swamp on the old corduroy road of cedar logs, I used to cast furtive glances over my shoulder and all about. 


\section{EVERY BOY WOULD BE A MIGHTY HUNTER}

I had dreams of being a mighty hunter some day -most boys have. You will remember that delightful little poem by the inimitable Robert Louis Stevenson, "The Land of Story Books." He voices the ambition of most boys in this direction.

But there was only small game in the forests about our neighbourhood. I remember there were golden plovers in innumerable numbers at certain seasons, and many wild pigeons in the woods. There were, of course, numberless 'coons, foxes, rabbits and squirrels, and I recall that while cutting wood in the bush my father captured a colony of flying squirrels. I tried to make pets of the little things but they proved very elusive and eventually escaped.

\section{THE OLD-TIME SHOOTING MATCH}

Shooting matches were of annual occurrence in most country districts, indeed, they were fixed festivals in the calendar of social events. 'Long about October, when the frost is on the fodder and pumpkin's in the pie, would be the festal season. Then the cotton-tail was fat from frequent visits to turnip patches, then the 'coon was sleek and oily as a result of nocturnal rambles in the farmer's cornfield; then the frolicsome squirrel was most ubiquitous.

Then, too, as the poet sings: "A fellow was 
a-feelin' at his best," particularly a country fellow. With the fodder in the shock, the threshing done, the turnips pitted, the fall ploughing well under way, the cider barrel full of the clarified nectarine of sun-kissed apples, and "applesass" and "punkin" pie a standing line on the bill-offare, was it any wonder that country young folks felt in a joyous mood and wanted to celebrate?

The boys would a-hunting go. I opine, however, that every one of them hunted a young woman first of all, and secured her promise that she'd go to the shooting match, supper and dance, as his "best" girl.

Then they'd choose sides, formulate a schedule of values on the game they expected to shoot, arrange other details and take to the woods. From sunrise to sunset the game had to be taken, points were counted by a committee and the losers paid the cost of the evening's entertainment which was usually held at the largest farmhouse available.

\section{COUNTING "POINTS" OF A SHOOTING MATCH}

At my home several of those festive events were staged when I was a small boy. I assure you I was an interested spectator while the ring-tailed appendages of the coon, squirrel tails, woodpeckers' heads and various other remains of the furred and feathered tribe were spread before the committee and tabulated in "points." If they were not all "fresh" there were likely to be lively 
squabbles among the census-takers-it was sometimes charged that certain hunters kept their trophies in "cold storage" from one shooting match to another.

\section{EVERYBODY DANCED IN THOSE DAYS}

In those dear old days 'most every one danced. The country boys practised the terpsichorean art on the granary floor in the old log barn by lantern light, when they went out to feed the stock. And the girls-well, they seemed to be born with the dancing devil in their toes. After the sumptuous supper of roast turkey and other fowl had been disposed of by those mighty nimrods and their girls, the big farmhouse dining-room would be denuded of everything portable-even the stove would be taken out to give free passage-way and necessary elbow-room.

There wasn't any high-class orchestra to flood the dance hall with melody, harmony and concord of sweet sounds in the form of fox trots, twosteps or other modern movements of the lithe and willowy waltzers of to-day. Instead just a fiddler -not a violinist - who would be seated on a chair in the sink or on a table and he'd proceed to rosin the bow and rip off such old favourites as "Old Zip Coon," "The Arkansas Traveller," "Money Musk," "The De'il amang the Tailors" and other popular and classical airs.

The first number would likely be a Circassian 
Circle and everybody in the language of the calleroff "took a dance." There were no wall-flowers at those old-time social events and the dances all had corners on them-square dances, you know.

If you have read Bret Harte you will recall that exquisite poem entitled, "Her Letter," in which the "Lily of Poverty Flat" describes a dance she attended in the days of the forty-niners in California. An incident of that historic occasion, indelibly fixed in her mind, is conveyed in the lines:

- "The night that I danced down the middle With the man that shot Sandy McGee."

Some of these fair country girls-the belles of shooting-match dances-doubtless, yet recall, with pleasurable memory, occasions when they danced down the middle or gave hand in grand right and left, or promenaded, swung, or sat out the dance in some secluded corner with the champion 'coon or squirrel hunter of the district.

\section{HELD UP A DANCE FOR A CHAW}

Some of those country dancers, the boys I mean, of course, were terribly violent-that is, they hit the lumber with their leathers till the windows rattled. I've heard it, too, but only a legend, that during the progress of a dance it was not unusual, in the away back period, for some youthful dancer to hold up a grand left and right movement until 
he could "touch" the fiddler, the caller-off, or some friend for a "chaw" of tobacco. As I've stated, this incident is legendary-likely just pure romance-or fiction, if you'd rather have it put plainer.

\section{SINGING AND STEP-DANCING}

Occasionally, between the dances, while the fiddler would be resting his elbow, or getting liquid refreshment in the form of sweet cider, there would be exhibitions of step-dancing by the young bucks of the neighbourhood, or a song by some pretty, fair maid. They used to sing "Annie Laurie," "Do They Miss Me at Home," "The Faded Coat of Blue," "Dublin Bay," "Old Folks at Home" and other favourites of a bygone age, and without any accompaniment. Organs and pianos were scarce, indeed, in those days.

\section{FIRST ORGAN OF THE NEIGHBOURHOOD}

Mention of organs sets me off in another direction. I remember when, as the Scotch folk call it, a "kist o' whustles" came to my home. It was the talk of the neighbourhood. Couldn't any of our folks play on it at first, but land sakes, that didn't stop them trying. Among us we got so we could pick out "Blue Bells of Scotland," without variations, except in the form of discords. I never hear that tune but I'm carried back in memory to that old farmhouse parlour and, in fancy, I see all 
my "ain folk" and the neighbours' boys and girls lined up there a-raising their tuneful voices.

I do not often "mess up" with poetry and when I do "mess" is the right word, but I just cannot refrain from an attempt at some wordy jingles about that organ in our old farm parlour.

Ah, that old-fashioned organ in our home down on the farm!

In fancy I can see it as it was in days of yore,

It gave to our old parlour a sweet peculiar charm-

But, alas; its strains are hushed forevermore.

'Twas the first one in the neighbourhood and cost a tidy rum,

But it surely made the place with gladness ring,

When Jennie pulled the stops out, you should have seen us come

For it took no coaxing then to make us sing.

The young folks on the farms about just couldn't stay away,

And in evenings and on Sunday afternoons

They often came to visit us and made our old home gay When they helped us sing those touching old-time tunes. Mother in the dining-room would ope the door and smile, While father quick his paper down would fling, And both with joyous faces and hearts that knew no guile

Would listen to us 'round that organ sing.

Loud and clear, they could hear

Our voices with that organ's notes a-blending,

How we sang, till rafters rang

Those tunes of other days on high ascending,

"Dublin Bay," "Old Dog Tray,"

"Nancy Lee," "Kathleen Mavourneen,"

"Some Happy Day," "Auld Robin Gray,"

"Bonnie Doon," "The Gypsy's Warning." 



\section{CHAPTER IX: THRESHING DAY}

THRESHING IN THE EARLY DAYS. THE FLAIL OR "POVERTY STICK." SOME HUMOURS OF THE "THRESHING DAY" ON THE OLD-TIME FARM. TRICKS THE BOYS PLAYED ON THE STRAWSTACK. AT THE HEAD OF THE STRAW-CARRIERS. THRESHING ON THE PRAIRIES AND A "SURPRISE" PARTY. THE DANCE AT THE RANCH. 



\section{CHAPTER IX}

\section{Threshing Dar}

MOST every one who knows anything of counM try life has some knowledge of a "threshing day" on the farm-that's the occasion when with the assistance of his neighbours, a farmer has his grain separated from the chaff and straw incident to its growth. In the good old days, long before the modern steam threshing outfit was thought of, the flail, or, as it was sometimes termed, "the poverty stick" was in general use.

When I was a boy there were several flails about our barn, although the horse-power and separator were then in evidence. Peas were usually flailed out and sometimes tramped or treaded out with oxen or horses on the ground just as in Biblical times the husbandmen separated the corn from the straw and chaff. It was held by some old-time farmers that peas were too much split or broken, by the threshing machine, and that the straw was reduced almost to cut feed and dust. Most farmers kept sheep then and clean pea-straw was looked on as a favourite food for the woolproducers. 


\section{LEARNING TO FLAII:}

Peas were harvested in those days with scythes and were usually cut a little on the green side of maturity and the straw made excellent fodder. Consequently, most farmers flailed out the pea crop and winter was the season for such work. The operation would be conducted on the barnfloor and it was quite a sight to watch two or three sturdy men start in on a bed of peas and with rhythmic motion of their bodies and with beat as sieady and regular as army drummers, pound and pound away till the peas would all be loosened from the pods and on the floor below the straw.

I do not recall that the flailers had songs or chanteys for such occasion, as sailors have, while reeling at the capstan of a ship, but such they might well have had. It would have made the toil easier and assisted the toilers in keeping time.

\section{"POVERTY STICK" DESCRIBED}

As a boy I considered myself quite an artist with the "poverty stick," and I remember that I attained efficiency only after I had dented my head in various places. It may be explained that the flail was formed of two pieces of woodhickory wood was the most favoured-the handle would be, perhaps, two feet longer than the wooden lash which was joined to it with a swivel, this latter cunningly made by hand. Unless one exer- 
cised some care it was quite within the realm of possibility to acquire a self-inflicted bump on the head. Of course, a skilled operator, using this old-time threshing instrument, would be immune but a greenhorn would be running in great luck if he escaped some hard knocks in the schooling of flailing experience.

Many farmers, too, used to thresh oats for feed, in the early fall, with the flail. Machine threshing, in those days, was done much later in the season than in these modern times. As horses were necessary for power and there was the ploughing to be done, threshing was put off till the fall work was well along and cool weather had set in. In order to get oats for horse feed, many farmers would flail sheaves, partly, without untying them, and put these through the machine to complete the job, when it arrived.

That's how I learned the art of hitting something else than my head, with a flail. I recall that I had dreams of beating a big drum some day but the fates intervened.

\section{"THRESHING DAX" ON THE FARM}

"Threshing Day," with the machine, was, of course, of more than ordinary interest to the farmer and his household. Dairying was not then so extensively engaged in, the grain crop being of premier importance. The neighbours would be there to assist and several would bring their teams 
along for use on the horse-power. I presume, even most folks, in this day, would know a horse-power at sight. It was a combination of one great cogged, metal wheel and several smaller ones and had wooden arms extending from the centre to which the horses were attached. The teams went around in a circle and the driver, with a whip of wood and buckskin, stood on a small platform in the centre of the merry-go-round affair. It was quite a science to keep five teams pulling steadily and if this were not effected, the result would be varying speed in the threshing machine and that meant poorly threshed grain. A trained driver could tell by the roar of the machinery if the proper speed was being maintained and so cracked his whip accordingly.

In those days a barn would usually be packed to the roof as there was little or no early threshing and there would often be a stack of grain behind the barn as well-an overflow, as it were, that could not be stored inside. It was often a twoday job to thresh out a farmer's crop. The machines in use then were smaller and the power limited to the dynamic energy ten horses could supply.

MACHINE, WELL NAMED'!

I recall that, as a small boy, I was lifted up by a thresherman that I might gaze into the greedy maw that contained the buzzing cylinder of the 
machine. On that separator's side was painted its name- "The Roaring Lion" - and my first look into it convinced me that it had been properly named, and I feared it just as much as if it had actually been a King of Beasts.

\section{ON THE STRAWSTACK}

I remember the strawstack was the place of chief interest for a small boy. There were, of course, no pneumatic tubes to put the straw where it was wanted, on the old-time machine, but there were straw-carriers, a sort of elevator, and there would usually be half a dozen men on the stack. These old-time strawstacks were sometimes enormous mounds of straw, built in pyramid form, and often higher than the barn roof.

\section{A FAVOURITE TRICK}

I have in mind recollections of a favourite trick that the boys of the neighbourhood used frequently to play in connection with "threshing day" and the strawstack. While the men would be at dinner, the boys would dig a hole on top of the rather loosely-built strawstacks, to the depth of five or six feet, or as deep as time and juvenile energy would permit. They'd cover the hole over lightly with straw, and set the pitchforks of the men in such a position that they'd have to walk across the pit to reach their tools. The young 
scamps would hide about and wait for events to shape themselves and when some old chap, on returning to work, would fall into the hole and, as it were, pull the hole in after him, in the shape of a big heap of loose straw, the joy of the boys would be full and complete. You see a fall of a few feet into loose straw was not likely to hurt any one, the trick, therefore, was not frowned upon and it added greatly to juvenile happiness.

The old strawstack made a great playhouse for children. They'd dig caves and grottoes into it and slide down its sloping sides like an alpine climber making a descent across a snow-field.

\section{THRESHING DAY-A SOCIAL EVENT}

The day's threshing over, I recall that the men lingered after supper and often a social evening would be spent at the farmhouse. Some of the young women of the neighbourhood who had been assisting in feeding the "hungry horde" would be there. There would be games-perhaps, an impromptu dance when the boys would shake all the chaff out of their hair. "Old Zip Coon" and other classics would be butchered on the fiddle or there might be a quiet game of euchre if the old folks had not too great a horror of "the devil's pasteboards." To-day, I am informed, all the men hurry home after supper and that the modern threshing is not the social event it once was and it is to be regretted that it is so. 


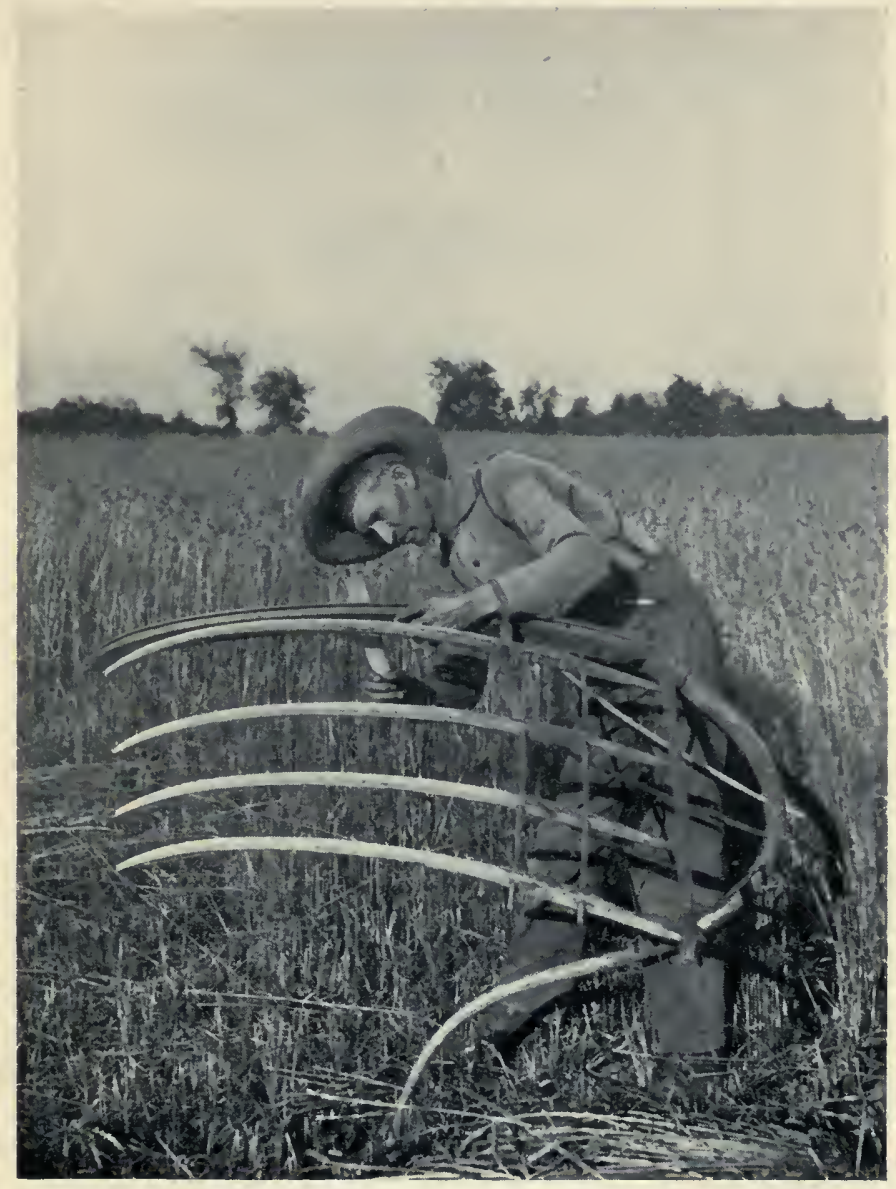

THE HARVEST FIELD OF OTHER DAYS. 

Dear reader, have you ever been stationed at the head of the straw-carriers at an old-time threshing, when the dust was so thick, as the saying is, that it could be cut with a knife? On a stack where there was plenty of air such a position was not too bad, but with the carriers running up into a barn mow, and almost against the roof, the man at the head of the straw elevator, occupied a tough, tough place.

I recall, when I was a lad, along with another youth, I was so placed. Room was scarce and the grain was heavy fall wheat. Early in the afternoon we had shouted down to the man who was feeding the hungry monster to hurry along-that we just couldn't keep from freezing for want of something to do. Just joking, we were, of course. When there was scarcely room to work, for the straw filled up behind us, he threw sheaves into that cylinder at a most remarkable rate. We were getting well winded but it wouldn't do to let the straw pile up at the elevator head as it would stop the machine, and would also be an acknowledgment that we were "all in." We were both young, dust-covered, thirsty, sweaty and exhausted. "I'll make those two young rascals cry 'Help' or 'Enough,'" the feeder, no doubt, was saying to himself. I may explain that the elevator was run by a long chain from the machine to a pulley at the top and as it was getting dusk, and he couldn't be 
seen doing it, my partner in distress threw the chain off the pulley and saved the situation. This chain occasionally jumped off of its own accord and so we were not suspected. It gave us a much needed breathing spell, also an opportunity to get the straw well back from our position and so we held the fort without a surrender. If that patriotic song "We'll Never Let the Old Fag Fall," had been extant then I guess we'd both have been singing it as we worked.

\section{AN OPEN CYLINDER}

I remember an open cylinder machine was used in our district to thresh peas. The grain was forked into the cylinder and straw and grain went out together to the ground behind. By some means a stone hidden in the straw was thrown in and a shower of broken granite and steel teeth from the cylinder flew into the air. The two young fellows forking in the grain faded away from the vicinity in haste, and no wonder. But the old chap who owned the outfit had this to say to them, "Ye'd make mighty poor sodjers, you two, if ye'd run from the likes o' that."

But the flail has gone forever and the horsepower, at least as a means of threshing, is almost a curiosity. Has the acme of efficiency been reached in the modern steam traction engine and self-feeding and stack-building separator? Who knows? 
In my homesteading days in the Northwest I saw power for threshing operated with oxen, but the teams moved too slowly and had to be rested often. The driver told me the animals got dizzy going around in a circle, and, to get best results, the critters should be unhitched frequently and turned about in the opposite direction to take the twists out of them. Of course, he was just stringing me.

During one of the "lean" years in the West, in the early eighties, many of us far Western homesteaders had difficulty in keeping the wolf from the door, indeed, some of us held that the wolves were in packs. Along with others of my neighbours I journeyed down into Manitoba and joined a threshing outfit. Wages were small but we needed the money real badly, consequently we put pride and the agricultural independence engendered within us by the ownership of prairie homesteads, behind us, and "hired out."

The party to which I was attached went threshing on the plains about Portage La Prairie, then one of the most prosperous farm settlements in the West. For four weeks we threshed in the fields and for many weeks longer from the stacks. Not a drop of rain fell in all that time. It was an ideal season for saving the Western crop. We had an ox-team and a horse-team with us-the former hauled the engine, brought water in a tank and pulled the straw away from the rear of the ma- 
chine with a long rope-the horses drew the separator about from place to place. We were boarded by the farmers but carried our bedding with us and slept in granaries, stables and sheds. Most farmhouses in those days were very small and the advent of sixteen men meant crowding. Those who were crowded out went to the stable or granary. To-day, I am informed, many Western outfits-and there are thousands in the West nowhave their own cabooses to sleep in and furnish their own meals.

Compared with the "Threshing Day" meals that I remember in Old Ontario, that Western grub was poor indeed. Down here at least, the women of the farmer's household vied with each other in old days, in furnishing the most appetising and attractive meals that could be produced. Out West we had potatoes, bread, glucose syrup, salt pork and a very indifferent quality of butter. Fruit was a luxury, indeed, and rarely on the bill-of-fare in any form. But we had appetites, oh, my!

\section{A "SURPRISE" PARTY}

I recall one evening that our outfit was domiciled in a bachelor's small frame house near Lake Manitoba. The whole sixteen were sleeping in the loft on the floor when a "surprise party" of young folks from High Bluff or Poplar Point, invaded that bachelor's home. They had driven nearly twenty miles across the prairie to "sur- 


\section{Threshing Day}

prise" him and it was a surprise, indeed. They didn't know he had a threshing outfit on his hands. There were fiddlers, lunch baskets and girls with the invaders and our noble sixteen stole into their clothing in haste and joined in the jubilation. We made a night of it. There was, likely, chaff in our hair, and I know there were no frills on our clothing. I know, too, that there was no chaff left on us after that dance. We shook it all off in our efforts to see which of us could hit the lumber hardest with our leathers. All the dances had corners on them and the fiddler "chawed" tobacco. The old boy who "called off" the dances was our ox-driver and he'd yell out instructions as if he were guiding his horned critters. As a social function in the "wild and woolly," it might properly have been termed "an enjoyable occasion."

\section{THE DANCE AT THE RANCH}

I never think of that festive evening without recalling to mind the following lines entitled, "The Dance at the Ranch":

Git your little sage-hens ready;

Trot 'em out upon the floor-

Line up there, you cusses; steady!

Lively now! One couple more.

Shorty, shed that ol' sombrero;

Broncho, douse that cigarette;

Stop that cussin', Casimero,

'Fore all the ladies; now set. 
S'lute your ladies all together;

Ladies opposite the same-

Hit the lumber with your leathers, Balance all, an' swing your dame.

Bunch the heifers in the middle,

Circle stags an' do-se-do,

Pay attention to the fiddle,

Swing her 'round an' 'way you go.

First four forward, back to places;

Second follow; shuffle back,

Now you've got it down to cases-

Swing 'em till their trotters crack.

Gents all right, a-heel and toeing;

Swing 'em, kiss 'em, if you can,

On to next an' keep a-going,

Till you hit your pard again.

Gents to eentre; ladies 'round 'em.

Form a basket, balance all;

Whirl your gals to where you found 'em,

Promenade around the hall.

Balance to yer pards and trot 'em

Round the circle double quick,

Grab 'em, kiss 'em while you got 'em,

Hold 'em to it if they kick.

Ladies, left hand to your sonnies, Alaman-grand right and left, Balance all an' swing your honeys, Pick 'em up and feel their heft.

Promenade like skeery cattle;

Balance all and swing your sweets;

Shake your spurs and make 'em rattle, Keno-promenade to seats. 


\section{CHAPTER X: SWEET CIDER AND "APPLE- SASS"}

SWEET CIDER AND CIDER "APPLESASS." THE OLD CIDER MULL IN VERSE. WHEN "APPLESASS" WAS A STANDING LINE ON THE FARMER'S BILL-OF-FARE. SCHOOLBOYS WHO SUCKED THE NECTAR OF SUNKISSED APPLES WITH A STRAW FROM THE CIDER BARREL. 



\section{CHAPTER X}

Sweet Cider and "Applesass"

"H ELLO, Jo! Been to the cider millq" "Yep!"

"Let's sample it."

"Here's a dipperful."

"How much did ye make?"

"Three, an' a barrel o' sass."

"I'll be comin' to see ye pretty often this winter."

Forty years ago one might have heard fragmentary conversations like the above, in the falltime, when two farmers met on the road or when villagers hailed each other, but, alas, the cider barrel and apple-butter crock or tub are not reposing in so many farm cellars now as in the good old days. In earlier days, on the old-time farm, when orchards were younger and apples more plentiful, "applesass"-cider "applesass"-was a standing line on the bill-of-fare in most farmhouses. Sugar, gem jars and imported fruit were not so plenteous then, when "applesass" held sway.

\section{"APPLESASS" WHLLE YOU WAIT}

After a generous store of sun-kissed apples had been safely pitted or given lodgment in bins in 
the cellar, the residue of the apple crop would be bagged up and taken to the cider mill to be converted into liquid nectarine or tasteful and appetising "sass." Many of the villages throughout Old Canada had cider mills, and several of these, that I knew as a boy, made a business of boiling down the cider-in other words, they made applebutter while you waited. Before that time cider, only, was made at the mills and this was boiled down at the farmer's home, in a big copper kettle, which would be loaned around by the man who owned the cider mill.

\section{TALLMAN SWEETS MADE FINE "SASS"}

It was not unusual for a farmer to take one or two big wagon-loads of apples to the mill and return with perhaps, two fifty-gallon milk-cans full of apple-butter and likely a couple of barrels of sweet cider. If he had a lot of Tallman Sweets a generous quantity of these would be used to sweeten up the cider and the "sass."

\section{THE NECTAR OF APPLES}

Kept in a cool cellar the "sass" and cider would remain sweet, that is it would not ferment, for a long time. In the meantime the farmer's family would be revelling-three meals per diem and between meals, too-on these tasteful products of the orchard. By the addition of certain ingredients-most every farmer had his own recipe-the 
cider would be improved and made fit for use throughout the year. There were many ways of treating it, and it was not impossible to get a fairly sumptuous "jag" by imbibing "hard" cider freely. There used to be a drink known as "applejack" whiskey, a form of cider, I suppose, but I have no intimate knowledge of such a beverage, but I've partaken of sweet cider from a barrel by the bunghole and straw route which was a very popular and pleasurable recreation with the boys in my day.

\section{THE OLD CIDER MHL.}

I memorised some verses once on "The Old Cider Mill." I don't know who let them trickle out. He'd got himself so worked up making them, I guess, that he hurried off to the cider barrel for a drink without signing his name. Maybe I cannot give them just as written but as nearly as I can recall them they ran:

If I could be a boy again

For fifteen minutes, or even ten,

I'd make a bee-line for that old mill,

Hidden by tangled vines down by the rill,

Where the apples were piled in heaps all 'round,

Red streaked and yellow, all over the ground;

And the old sleepy horse goes 'round and 'round

And turns the wheels while the apples are ground.

Straight for that old cider mill I'd start,

With light bare feet, and a lighter heart, 
A smiling face, a big straw hat, Home-made breeches and all $o^{\prime}$ that. And when I'd got there I'd just take a peep, To see if old cider-mill John was asleep, And if he was I'd go snooking around Till a big round wheat straw I'd found; I'd straddle a barrel and quick begin To fill with cider right up to my chin. As old as I am I can shut my eyes, And see the yellow-jackets, bees and flies A-swarming 'round the juicy "squeeze" And bungholes; drinking as much as they please. I can see the clear, sweet cider flow From the press above to the tub below. And a-steaming up into my old nose Comes the smell that only a cider mill knows.

You may talk about your fine old Sherry, Champagne, Canary or Tom and Jerry, But of all the drinks of press or still, Give me juice from that old cider mill. A small boy's energy and suction power For just ten minutes or third of an hour, And the happiest boy you ever saw You'd find at the end of that wheat straw. And I'll forego for ever more All liquors known on this earthly shore.

ENTICING FOOD AND DRINK

On festive occasions in the farmhouse of other days, and at threshing "bees" the cider jug would be passed around. Properly made it was a refreshing and healthful drink, and that boiled-down cider "applesass," with Tallman Sweet apples 
added, in quarters, during the boiling process, was mighty appetising and enticing food. It was brick-red in colour and many farmers' wives added lemon and other flavourings to it, that made it, indeed, a food fit for the gods.

That "sass" was used, too, to make tart pies and I never knew that any one had to be twice asked to take a second piece, indeed, the womenfolks just had to hide those pies if they wanted to get them to the table. That lattice-work upper crust, with the "sass" fillin' shining through, just made them irresistible.

\section{SCHOOLBOYS USED WHEAT STRAW}

As a schoolboy I recall that I used to pass a farm on my way to the seat of learning where they had a large orchard and, consequently, a liberal supply of "sass" and cider. A barrel of sweet cider had been left in the root cellar, under the barn, and the extreme cold of winter partly froze the contents of that barrel. The watery part congealed but the centre of the barrel was a syrupy fluid-the very nectar of the sun-kissed apples. We schoolboys, with our shining morning faces, used to linger lovingly about that barrel. We'd break through the ice at the bunghole, insert straws and fill up on condensed apple juice till our little "tummies" were like to burst. We just sucked the whole centre out of that barrel and, I cpine, that that farmer had a very poor quality 
of vinegar next season. That's what he intended that cider would become in the sweet by-and-by.

\section{SYMPTOMS GAVE IT AWAY}

One morning, at school, after a visit to the cider barrel one of my chums was taken ill with severe pains in his stomach. The teacher named himself a committee of investigation. If you've read Joel Chandler Harris's story of Brer Rabbit and the Tar Baby you'll remember that Brer Rabbit began his diagnosis of the Tar Baby's sickness with the question:

"Where does yo' symptums seem ter sagacitate?"

But that wasn't the way with our teacher. With a look of real sternness on his face he came direct to the point with the query: "Now, Jo, what have you been overloading yourself with?"

Of course, Joe had to furnish a verbal copy of the family breakfast menu and much to the consternation of several of us, also told about our visit to the cider barrel. Well, to put it briefly we didn't have an opportunity to insert wheat straw into the bunghole of that particular barrel any more. But we consoled ourselves with the knowledge that we'd pretty well exhausted its sweetness anyway. 
HOW'S YOUR CIDER KEEPIN'?

In those days when one farmer would visit another in the winter season, likely, among the first questions asked would be, 'How's your cider keepin'?" The answer would be given by the host bringing up from the cellar a big pitcher so full, that beaded bubbles would be winking at him from the brim, and the visitor would be asked to sample it. They say, too, that it was difficult to get hired help then if there was no apple-juice on the premises.

\section{TART PIES WITH "SASS" FILLIN"}

I don't know that it has ever been poetically observed that in the spring a small boy's fancy fondly turns to thoughts of rhubarb pie, but I do know that in the fall-time, years ago, on the farm, both the small boys and the old boys had violent hankerings for cider "applesass" and tart pies with "sass" fillin'.

The qualifications of a country girl in days past, considered necessary, before she became a bride, were, that she could bake bread, make butter, etc., and in some districts a knowledge of making "applesass" properly was deemed important. But, alas, we have gotten far and beyond the "applesass" period. Mind you, I am not cavilling about the accomplishments of the modern farmer's daughter but just bewailing the fact that those 
pies I used to know and love, have, as it were, gone down the back entrance of time.

Of course, there are those finical folk who hold that cider is only made from wormy apples and not fit for human consumption. But come to think of it a drop of water is made up of crawling, creepy things, and a dish of raspberries and cream is said to contain more or less of insect life. In the case of cider it may safely be assumed that the worms are all dead anyway, after going through the mill and the press.

Even the poets, and some of those who can do better than write limericks too, appreciate, and, likely, drink cider and some of them have paid tribute to cider and "applesass" in verse. 


\section{CHAPTER XI: THE " 'COON HUNTERS'" CLUB}

WITH 'COON-HUNTERS' CLUB. SOME HUMOURS OF THE HUNT FOR THE RING-TAILED CORN THIEVES. TREED A CAT BUT FINALLY THE CLUB GOT ITS 'COON. OLD FARMER GROWS REMINISCENT IN VAIN ATTEMPT TO DISCOURAGE HIS YOUNGEST SON FROM 'COON HUNTING. 



\section{CHAPTER XI}

\section{The " 'CoOn Hunters'" Club}

SINCE pioneer days 'coon hunting has been one $N$ of the favourite sports with the country boys in fall-time. In some districts in Canada there were regular 'coon-hunting clubs organised, the members of which would sally forth 'long about October to harvest pelts and bottle up, for winter use, a few gallons of 'coon oil. In the top-boot period this 'coon oil was in much demand as a dressing for footwear.

The possession of a good 'coon dog was, in earlier days, said to give the owner of such a canine, a standing in the community in second place only to that occupied by a good fiddler.

\section{WITH THE 'COON-HUNTERg' CLUB}

I was a member, in good standing, in a 'CoonHunters' Club and I recall an occasion one fall, when the corn was on the ear and the woods were said to be full of 'coons. The President had issued an invitation, or rather, an edict, summoning his force of hunters to convene at a certain crossroads to embark in the delectable enterprise of hunting the ring-tailed denizens of the corn patch. 
It was a charming evening, the date chosen for the nocturnal harvest of 'coons. There was a cloudless sky and the man in the moon was one vast substantial smile.

"If there ain't 'coons out to-night, I don't know nothin'," observed the President as he ran his eye over the landscape and his faithful following.

The dog, a mongrel with a stub-tail, and bearing the scars of many battles, was straining at the leash-a rope halter, appropriated from a farmer's stable. The canine was the subject of much patting and many words of endearment.

A musically inclined young 'coon hunter broke into song trilling forth the most recent parody on "The Old Grey Bonnet."

"Say, young fellow," broke in the chief 'coon hunter, "if you will warble, let it be a 'coon song, this is no golden wedding affair with blue ribbons on it. Sing 'coon melody or cut it out."

\section{THE PRESIDENT'S ADDRESS}

"Boys," said the President, as the gang stood at attention on the roadside waiting for the word to take to the woods, "maybe a few directions wouldn't be amiss. Follow the dog, and don't be misled by the yelping of an ordinary farmhouse cur and wander off. This is a mighty big country and after night it's hard to tell a concession from a sideroad. Don't try to break through a barbedwire fence, the wires don't always break when you 


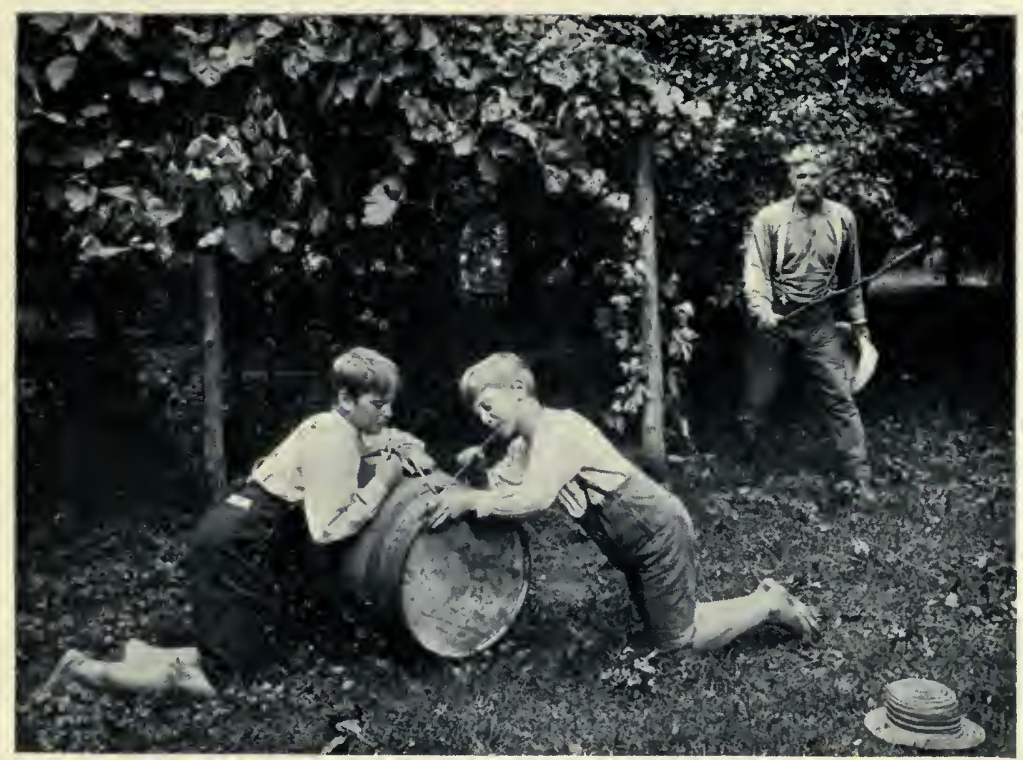

THE CIDER BARREL, THE SMALL BOY AND THE WHEAT STRAW. 

run against them. Remember it's 'coons, not cats, we're after and that the first man at the foot of the tree when the dog trees a 'coon gets all the glory as well as the pelt. Now, let loose the dog there, Foley, and everybody hunt 'coons."

The hunt was on in dead earnest. Over against a dark woods was a corn-field and towards this the Club followed the dog on the run. About the shocks of fodder corn "Old Tige" sniffed and to the delight of the hunters gave vent to a sharp bark and headed for the woods on the run.

"He's struck a scent, boys," shouted an enthusiast.

"'Good 'Old Tige,' there's no better 'coon dog on earth," chirped another member of the Club. The remainder of the members said nothing, feeling that they needed all the breath they had for the foot race which was then in progress.

At the foot of a scrubby oak "Old Tige" set up a vociferous howling and a youth with climbers soon shinnied up the tree. After a long search among the branches he located a dark object out on the end of the limb.

"Here he is, boys, watch out below there," shouted the climber as he violently shook the limb.

Hurtling through the air came the 'coon and landed on "Old Tige's" back-not a 'coon but a black cat, which leaped away into the darkness, but not before its identity was discerned and not before it had added a further scar to the dog's already numerous collection. 
NO SUOH WORD AS "FAT""

In the lexicon of a real live 'Coon-Hunters' Club there is no such word as "Fail." Through numerous dewy fields of third growth alfalfa the hunters took their way, also across ploughed fields where the going was muddy and tiring. Their objective was another corn patch.

"Where's that fair-haired young banker?" asked the Chief as he ran his eye over his followers. A young banker from a neighbouring town had been invited to join in the hunt and had accepted without hesitation.

Everybody looked but found him not.

"He's gone and followed a cow most likely, for I heard him say a while ago that he was hungry for a drink of milk," said Jack Fleming.

"Scatter, ye minions, and find that lost boy," shouted the Chief. "But say," he continued, before they had time to move, "can any of you say whether this is a concession or a sideroad? If you can't, b'gosh, I think the whole outfit is lost."

"Right here where we're standin' is the sixteenth concession," volunteered Jo Thompson; "you can't fool me on country roads about this neck of the woods."

"Ah, gwan, yer stringin' us, Jo, this is a sideroad, there's burdocks growin' along this track that would pull a fellow out of his wagon," poured from Sam Peters.

There under the glimmering stars, for half an 
hour, they had a heated discussion. Some held they were in one township, some in another.

"Where's that there North Star? Find that, boys, and I'll straighten this thing out," said. the Chief, and he pulled from his pocket a compass.

"Say, is this a Peary or a Doc. Cook that's leadin' us?" asked Si Beattie. "First time I ever went huntin' 'coons with a compass."

At this juncture there was a rustling in the weeds by the roadside and in came the lost 'coon hunter. He was wet with dew to his knees and carried more burrs than a yearling colt that had run wild in some back pasture field all summer.

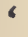

"I've walked until I'm nearly dead,

A weary, weary distance,

I beg of you, kind sirs," said the wanderer, "A trifle of assistance."

"Here," said the President, "cut out that Father Tuck nursery rhyming. Help him up on the milkstand, boys, and let's hear his story."

After the worn and weary one had somewhat recovered he gave the Club members a spiel about his adventures that made Teddy Roosevelt's twovolume story, "Hunting Big Game in Africa," look like thirty cents. In the language of the story books he went on and on, he had seen heartie beasts and $b$ 'ars, griffins, goblins and sheep.

"What about 'coons?" asked the President, who had been getting uneasy at the length of the recital. 
"Never saw a thing that looked like one," said the returned traveller from the land of adventure.

"Well, consarn it, if you can't see 'coons quit seeing them other things. This is no kindergarten party playing with Teddy Bears," snapped out the Chief.

A fire was lit and some ears of corn were roasted and after a roast-corn lunch the Club went forth again to harvest 'coons.

At the foot of a lone tree which stood adjacent to a large corn patch "Old Tige" fairly stood on his hind legs and barked in a most convincing way. The President himself donned the climbers, and after a hard struggle through the intervening branches, reached the top and there, gleaming at him, were a pair of real 'coon eyes. He shook the limb and shouted as he shook:

"He's comin', don't let him get away!"

But good "Old Tige" was there and met Brer 'Coon in the air. There was a fierce fight for, perhaps, five minutes, with every member of the Club brandishing sticks or shouting words of encouragement to the dog.

The Club had its 'coon.

There was nothing further to do but pass a resolution of confidence in the Chief and "Old Tige." The 'coon was presented to the young banker and he was made an honorary member of the Club. 
AN OLD FARMER AND 'COON HUNTING

In these days it is usually the farmers' younger sons who go 'coon hunting. On pleasant September evenings they may be seen sitting on milkstands at farm gates, talking of the approaching hunting season and incidentally exchanging confidences as to where the best early fall apples are to be found. Information about the best corn patches is also carefully compiled for future reference and the merits of dogs as 'coon chasers are discussed with seriousness and deep interest.

"Where were you boys so late last night?" is often a farmer's morning inquiry.

"Oh, a few of us were just talking about 'coons and things," answers the youthful Jo.

"Coons be hanged, there's not a 'coon within five miles of this farm nowadays. When I was a boy," continued the farmer, "there were 'coons. We didn't have to appoint a committee to receive reports. We just went and harvested the ringtailed fellows. I've known me and your Uncle Jim to have a whole row of 'coon skins tacked up to dry on the north side of the barn. And 'coon oil, why we'd have gallons of it every fall. But there ain't no 'coons now, so what's the use of you boys losing your sleep.",

"'Coons, no 'coons!" pipes up young Jo, "there's 'coons right in our bush and just as soon as the corn gets right we're going to get them." "All right, Joey, all right, bring on your 
'coons," replies his father, seeing that his favourite was enthused with the prospects of a big 'coon harvest, "but I don't think you'll need much board space for the pelts and not more than a twogallon jug for the oil.",

"Yon know the Smith boys over by St. Ives," broke in Jo, who wished it distinctly understood that he couldn't be discouraged by talk of scarcity of 'coons, "well, the Smiths and a few other boys were out one night last week and got two whoppers. Their dog isn't half, as good as ours neither. They treed two big fellows the first corn patch they went to and one of the Smiths climbed the tree and shook the two out of the branches. The dogs were waiting for the 'coons to fall. My, but there must have been something doin' just about then," said Joey with a yearning look as if he couldn't wait for the shades of night to fall when he hoped to be one of a 'coon-hunting party.

\section{THIS CRITTER WASN'T A 'COON}

"Didn't I ever tell you," said the farmer with a picture of boyhood's happy days in his mind, "how your uncle Jim and me got fooled one night when we were out huntin' 'coons many years ago? We'd had great luck that fall. We had one row of 'coon skins clear across one end of the barn and had made a start on the second row. This night I speak of was along about fall fairtime and the woods were just full of 'coons. We 


\section{The "Coon Hunters" "Club}

161

had gathered in three fine fellows and were just thinkin' of headin' for home when old Sport set up a monstrous howlin' at the foot of a tree overhangin' the creek. The leaves were pretty thick on the trees and, although we went round and round and eyed every limb for a dark spot in the branches, we couldn't see Mr. 'Coon anywhere.

" 'Guess it's a case of climb,' said your Uncle Jim and up the tree he went, leavin' me and old Sport to handle the 'coon which he expected to shake off a limb.

"Jim climbed and climbed and after a lot of lookin' about got his eye on an animal away out on a limb overhangin' the creek. He shook and shook the limb, but the critter wouldn't let go and Jim crept out farther so he could put more power into the shake.

" 'Say, Joe,' he called down to me, 'this critter's got fiery eyes and looks as if it wanted to fight.' He hadn't no more'n got out the words when there was a screech that made my blood run cold and a snappin' and a crashin' of branches followed quick. Somethin' fell with a splash into the creek-it was Jim and the animal-they came down together an' both a-yellin' fit to split. There was four or five feet of water just below that tree an' you'd a-thought a hundred horse-power turbine was revolvin' in it for a few seconds. Old Sport was spellbound an' I was scared till my hair stood on end. Before we recovered Jim came sloshin' through the water to the bank an' out on 
the other bank I saw a dark object makin' tracks for the tall timber."

"An' you let it get clear away," said young 'Joey.

"Yes, an' we was mighty gla'd to let it go. That there 'coon your Uncle Jim and me had been a-foolin' with was either a wildcat or 'painter' or catamount," continued the old man.

"Jim got off with a few scratches and bruises but it kind of stopped our finishin' out that second row of pelts for a few nights."

"Wish we could tree one of them animals now," said young Joey.

"What, you won't be scared into stayin' at home nights! Well, well, you'll just have to go 'coon huntin' an' take your chances," said the old farmer as he looked with pride on his youngest son. 


\section{CHAPTER XII: THE CHAMPION 'COON HUNTER'S STORY}

WHEN THE CORN WAS ON THE EAR AND THE WOODS WERE FULL OF' 'COONS. AN OLD-TIMER TELLS OF A RECORD 'COON HARVEST. SHOOK THEM OUT OF A TREE JUST LIKE APPLES. HAS SOMETHING TO SAY ABOUT DEER HUNTING, TOO, AND HOW HE ONCE SHOT A DEER OVER HIS SHOULDER. NEVER MISSED A SHOT. FOLKS IS MIGHTY UNBELIEVIN'. 



\section{CHAPTER XII}

\section{The Champion 'Coon Hunter's Story}

"T'VE got a 'coon-hunting yarn that maybe you I youngsters could stand to hear," a pioneer announced by our kitchen nire one winter evening. "An' I want to tell you," he continued, "that there ain't anybody, unless he's as old or older'n me, that knows any more 'bout them ring-tailed corn thieves than me, either. 'Coon huntin' them times, was worth stayin' out o' nights for."

"Good old times, weren't they, away back in the woods," one of our number said, by way of encouragement, and in keen anticipation of a 'coon-hunting story at first-hand. The veteran of pioneer life straightened up under his load of eighty years and lighting his pipe proceeded thus to make history.

\section{WHEN 'COONS WERE PLENTIFUL}

"Good old times, boy, yer jest right they were. I can remember as if it was yesterday when my brother Joe, that's dead an' gone, an' me, one fall catched eighty-seven 'coons an' right in our township, too.

"Eighty-seven, yes, that's what I said. We cut 
a nick in a stall-post in the old log horse-stable for every 'coon we took, an' them figures stand correct. That stall-post is gone long since but my memory is just as good, though I'm stiffened up considerable an' gettin' along to near the end o' the trip.

"We had an old brindle dog that would lay over anything o' the dog kind in the way o' gettin' 'coons, an' Joe an' me-well, we thought we was a pretty fair team o' coon hunters.

"That fall I'm speakin' about the corn was on the ear early and the woods was full o' 'coons. $\mathrm{O}^{\prime}$ course, there was other things in the woods them times but 'coons was our meat, so I won't take you off the track $0^{\prime}$ them ring-tailed fellers.

\section{BARN WAS WRAPPED IN 'COON PELTS}

"We started in to harvest them about the middle of August, an' kept gettin' ones an' twos an' threes every night till long about the last o' September, when we began to double up an' take them by fours an' fives an' sixes. By that time every log in our old barn was clapboarded with 'coon skins an' we'd begun to side up the milkhouse.

"'Say, boys,' said Dad to us one evening, 'ye'll just have to let up on that coon huntin'. We don't mind yer wrappin' up the barn in fur, but yer mother says them there fresh coon pelts is taintin' the milk.' 
The Champion 'Coon Hunter's Story 167

"That there very night Joe an' me went out an' broke the record.

"' 'Well, what luck?' shouts Dad, as Joe an' me, along about midnight, crept up the ladder to our bed in the garret.

" 'Oh, just seventeen,' answered Joe as if he was badly disappointed, when we was both feelin' as if we'd eclipsed old Nimrod's place in history.

"We could hear Mother an' Dad talkin' low, fer a minute and then Dad shouts out, 'Yer mother says there's half a pie on the pantry shelf that wouldn't hurt ye, but mind, not one o' them there skins is to go on the milkhouse.'

\section{A TREE FULL OF' 'COONg}

"But what I was goin' to tell ye about was how we broke the record an' got them seventeen coons. The old dog got three on the ground in the corn patch, an' then he began cavortin' around a scrubby oak tree that stood by itself in the clearin'. He fairly danced on his hind legs under that tree an' Joe an' me just tumbled over ourselves gettin' there. There seemed to be a 'coon on every branch.

" 'A hull tree of 'em,' shouted Joe, an" he was pretty near right. Up it he climbed an' the old dog an' me waited for events to shape themselves underneath. Joe gave the first limb he got to a shake an' down came a couple of big fellows. One of them landed right on the old dog's back and the 
other one clawed my ear an' cheek as it was fallin'. $\mathrm{Me}$ and my partner, the dog, was real busy for a second or two an' we hadn't time to catch our breath when Joe shook down two more o' the corn thieves right a-top of us.

"'Here, you Joe,' I shouted, 'let up on that shakin' for a minute or two or I'll quit the job.' But I hadn't any intention o' quittin'.

"'Shakin' 'em a little too quick for you, am I?' called back Joe. Joe had it in for me an' knowin' that he had me in a tight place he was tryin' to pay off an old score. He knew I'd work myself useless before I'd let one o' them 'coons get away. It would have been a serious reflection on me if I had.

\section{SHOOK 'EM DOWN LIKE HARVEST APPLES}

"It was like this: Joe an' me had been out gettin' harvest apples a few nights before an', as usual, when we was huntin' things, Joe did the climbin'. Before he got down from the tree I had gathered up rather more'n my share o' the apples an' Joe was a little peeved. Now, he thought, he'd get even by buryin' me in a pile o' 'coons.

"I was kind o' riled an' just sung out, 'Oh, let 'em come, Joe, I guess we can handle 'em as fast as you can git 'em here.' Down they came, two at a clip. Talk about 'coon killin'-me an' that old dog certainly made some smart moves. 
The Champion 'Coon Hunter's Story 169

“'All down,' shouted Joe, when me an' me fightin' partner were just about winded.

"' 'All dead,' I called back, an' then we laid 'em out in a row an' counted 'em in the moonlight. There was seventeen of as fine a lot o' 'coons as ever tasted corn.

" An' I think, that that there night's 'coon huntin' has never been equalled in these parts. These here young chaps that's been talkin' 'coon huntin' nowadays are in the first book at that kind 0 ' work. Of course, they haven't got the 'coons now that we had in the good old days, but I doubt it, anyway, that there's any such three coon hunters in the land like Joe an' that dog an' me."

"Pretty good 'coon story," said I, and I suggested that he fill up his pipe in further anticipation of hunting history. I was not disappointed.

"'Maybe ye've heard about deer huntin' an' buck fever," said the old man as he wreathed himself about with clouds of aromatic smoke. "Maybe ye could stand to hear about one $o^{\prime}$ my deer hunts."

I Kastened to assure him that we'd be delighted and he proceeded to unroll the films of memory thus:

\section{A-CHASIN' THE DEER}

"One day in the fall of ' 54 I made the record of my life in deer shootin"," he started off with his story. "With my old smoothbore rifle and my dog I wandered off into the woods an' that was a 
day for deer for sure. I hadn't gone more'n a mile from home when I started up a big buck and a couple of does."

"And you got the whole bunch at one shot," I broke in.

"Now, you hold on. I'm tellin' this," he responded. "I've heard fellows tell of gettin' two deer at one shot, but I always set them down as a little careless 0 ' the truth. I got the whole three but it took three shots. And I didn't stop with three for before sundown, over near the big black ash swamp I got two more."

"Five bullets, five deer, eh? Some record, surely," I gasped out.

\section{NEVER MISSED A SHOT}

"Yes, that's it. Bullets and powder cost big money in them days, so we couldn't afford to waste them. Tea wasn't done up in lead them times, in fact, we didn't often have tea. But we had saddles o' venison and venison steaks in plenty and we didn't work the lever o' a Winchester and shower the bullets all over the landscape the way these Muskoka hunters do. One bullet and in the right place, that was the way us early deer hunters did it.

SHOT A DEER OVER HIS SHOULDER

"I want to tell you about the last deer I got that day. I was walkin' along a log in a black 
The Champion 'Coon Hunter's Story 171 ash swamp an' it was a mighty slippery log, too, for it had been rainin' an' the bark was off the fallen tree I was on. I heard a slight noise off behind me and lookin' over my shoulder I saw the head of a big buck. It was lookin' right in my direction. If I made a move I knew it would vamoose and as I was tired with the long tramp through the woods, I did not feel like followin' far.

\section{THE LOG WAS SLIPPERY}

"There I was, mind you, on a slippery log, with my back to a big buck and afraid to move for fear he'd give me the slip. I just slowly swung that old smoothbore rifle around till it was almost pointin' over my shoulder. I was young then and my joints worked easy, that was how I twisted my neck enough to look back along that rifle barrel. But I did it and just when the sights lined up between the two eyes of that buck, that was when I pulled. O' course, he went down in a heap and my feet slipped on the log just at the same moment and when I came to, like Dr. Foster as went to Gloucester in the nursery book, I was wet up to the middle."

Pretty good shot, it certainly was, some one interposed.

"That was the first and only time I ever shot a deer over my own shoulder and I can't call to mind that I ever heard tell of anybody else doin' such a thing. I've heard o' desperadoes out West shoot- 
in' sheriffs and deputy-sheriffs over their shoulders, but takin' in all the circumstances, that there shot $o^{\prime}$ mine was pretty mighty good. That slippery log, a heavy gun and the deer a hundred yards off with just his head in view-say, I don't believe there's any o' them Muskoka chaps could have done that job."

FOLKS IS MIGHTY UNBELIEVIN'

"I could tell you of a few other little affairs I've had in the woods, but-well, as like as not some interferin' neighbours o' mine might be sayin', there's that Old Jim — he's forever tellin' them huntin' lies o' his'n. Folks is mighty unbelievin' now, anyway. 'Tain't like it used to be neither in believin' nor buntin'," snapped out the old-timer. 


\section{CHAPTER XIII: BY THE FIRESIDE}

BY THE EARLY SETTLER'S FIRESIDE WHEN THE'TALLOW DIP OR CANDLE WAS THE ONLY LIGHT. AN OLD TIMER'S B'AR STORY. A BOY'S ADVENTURE WITH BEARS IN A BASSWOOD STUMP. A REMARKABLE DÉNOUEMENT WHICH RESTORED A LOST BUTCHER KNIFE TO ITS OWNER. 



\section{CHAPTER XIII}

BY THE FIRESIDE

7 HE farmer's fireside in olden days was a most 1 enticing and attractive place for young and old. In the early or pioneer days, the log cabins on the bush farms had fireplaces of stone and it was from one of these that the blazing logs threw the ruddy tints of health on my youthful face, and it was there by the hearth-side that I drank in the stories of the pioneers. The tallow dip or candle was then the only light in the farmer's palace of logs, supplemented, of course, by the glow from the open hearth.

Books were few in those days, and newspapers a rarity, and conversation was the chief medium for distributing or conveying the news of the neighbourhood or district. It was also the means of much entertainment and such a condition naturally developed the story-telling art. It is surprising, too, how fascinatingly and artistically, some of those early settlers could present the rural happenings in story form by the fireside. It was the age of romance in this country for the shadow of the deep woods was still upon it. Many of those pioneers, too, had memories of the Old Land with its superstitions, folklore and legends. These fur- 
nished themes for tales oftentimes given with much garnishment and frilling by many a Canadian fireside.

Stories of hunting and adventure appeal to the small boy everywhere in the world, I presume, and always will unless ancient appetites are forgotten. As a lad I lent a willing ear to tales of $b$ 'ar, 'coon and deer hunting.

\section{'AN OLD SETTLER'S B'AR STORY}

I remember a weather-beaten and grizzled old pioneer, who was a frequent visitor at our fireside, and who never failed to respond to our childish request for a " $b$ 'ar" story. Here's one of his fireside thrillers.

"I don't think I ever told ye the story about capturin' a couple o' young b'ars in a hollow stub an' other incidents pertainin' thereto. It's a real good b'ar story, the best I know of.

"I remember the hull particulars as if it happened yesterday an' I'll give ye all the facts, keepin' nothin' back.

"Dad had shot a deer, an' the mornin' after, says he, 'Jo, take that passle o' venison over to Jim's an' tell him to lend ye his butcherin' knife for we've got to kill that there porker next week.' Butcherin' knives were scarce in this neck $0^{\prime}$ the woods in them days an' Jim had the best one in the settlement. I took the venison in a bag and tramped through the mile or so $0^{\prime}$ woods. Jim 
liked venison an' seemed mighty glad to get it an' before handin' me the butcherin knife he whetted it up good and sharp.

"' 'Mind ye now, boy,' says he, 'don't be cuttin' gads an' playin' fool tricks wi' that knife. No throwin' it at trees to see if ye'd qualify for an Indian Chief or a bloody cutthroat pirate.'

"I promised to take good care o" this hogstickin' weepon an' it was a mighty good thing for me that I did as things turned out. From the days o' my infancy I had always a hankerin' to nose around the woods, an' on my way home I wandered some in the primeval forest.

"Comin' to a big basswood stump I was hesitatin' whether or not to carve my name when I heer'd scratchin' inside. Mind ye, I was only thirteen years old or thereabouts an' that scratchin' an' scramblin' I heer'd, kind o' scared me.

"Then that there habit o' mine o' nosin' 'round took holt o' me an' I stuck my ear ag'in the stub and listened. There's somethin' lively in there an', b'gosh, more'n likely it's a young b'ar, I says to myself. Nachually bein' raised in the woods, made me some interested in b'ars.

"If there's a young b'ar in that stub, says I, I got to have it.

“'Hangin' the empty sack about my neck I shinnied up that stub an' peerin' down into the dark holler I saw not one, but two young cubs. They were little chaps about the size o' a woman's muff. 


\section{TWO YOUNG BEARS}

"Then I let myself down into that holler stub without thinkin' how I was goin' to come up. It didn't take me more'n two seconds to drop them little furry chaps into the bag, but climb my best I couldn't make the grade out. An' there I was. "Trapped fair an' square, says I, an' then I thought o' Jim's butcherin' knife. Jim's words 'take care o' that knife, boy,' didn't stop me for a second. In a wink I was hackin' an' slashin' at that stub faster'n any red-headed woodpecker ever stabbed holes in a rotten tree searchin' fer grubs.

"It seems a most amazin" thing but it never occurred to me before I went in that ol' tree that the lovin' parents o' them cubs was only temporarily absent.

" $I$ 'd been so busy hackin' and slashin' that I didn't hear the old she-bear comin' to the top o' the family residence, an' the first inklin' I got that somebody was comin' was when the light at the openin' in the stub was shut off.

"It came to me all o' a sudden jest what a fix I was in. As I've said, I was young, but I had gumption enough to know that the mother o' them cubs wasn't goin' to excuse me on account $o^{\prime}$ my youth. Explainin' would be o' no use fer there was her two cubs in the bag. 
THE OLD B'AR'S HOME-COMIN'

'TThe big lump o' darkness was descendin' tail foremost an' was almost atop o' me when it came to me, like a flash o' light, that I might take the elevator route out $0^{\prime}$ ' that stub.

"Twistin' the top o' the bag in a knot an" squeezin' it between my knees, with the cubs squirmin' around in it, I grabbed the old gal's tail with one hand an' socked Jim's butcherin' knife into her hindquarters.

"There was more surprises than one in that b'ar's home-comin'. With a howl that made that old stub tremble she started up, an' there I was clutchin' her tail wi' one hand an' sockin' the knife into her wi' t'other, an' not forgettin' to keep my knees tight together on that bag o' young b'ars.

"Did she stop at the entrance? Nary a stop. She kept on goin' with a jump from the stub an' landed me an' the bag o' cubs on a brush-pile more'n twenty feet away. The tumble broke my holt, but the b'ar never stopped goin' as fur as I could see.

\section{LOST THE KNIFE}

"Consarn the luck, anyway, says I. What did she want to come interferin' fer an' there I've gone and left that butcherin' knife o' Jim's stickin' in her back. Dad'll wallop me sure an' Jim'll 
claim one $o^{\prime}$ them cubs fer pay fer his loss on that knife.

" $A n$ ' now comes the most remarkable feature as ever concluded a b'ar story.

"I hadn't more'n straightened things about an" was gettin' my bag o' b'ars on my back to strike out fer home when along came a neighbor o' ours. His clothes was torn to ribbons an' he was drenched with blood.

" 'What in thunder have you been doin' tearin' yerself up so amazin'?' says I.

" 'Wildcat,' says he, 'been rasselin' with a wildcat.'

"Then I up an' told him my story an' how troubled I was 'bout losin' Jim's butcherin' knife.

\section{KNIFE ARRIVED JUST IN TIME}

"The man pondered fer a spell an' then gave me the particulars 0 ' his scrap. 'The wildcat had me down,' he said, 'an' it was gettin' mighty near the last round an' I expected it'd be all up with me, when I heer'd a rumpus in the scrub. There was a b'ar comin' tearin' towards us with its head down an' its eyes jest hangin' out on its cheeks. The b'ar had got most on top o' me an' the wildcat an' then seein' us it turned so quick in its tracks that it almost throwed itself down. Jest as that b'ar turned somethin' shot off of her an' fell square in my hand. It was a butcherin' knife covered with blood. That, of course, gave me a 
little advantage in my scrap with the cat an' I soon ended the fight.

" 'Here's yer knife, young feller,' says he, handin' me Jim's favourite pigsticker, 'an' it was a mighty lucky thing fer me that ye lost it the way ye did, an' if that old b'ar hadn't just passed it along to me in the nick o' time there'd a' been a widow and orphans in our clearin'.'

"That's my very best b'ar story, children," said the story-teller as he lighted his pipe. "I've told it a good many times. My Dad used to want every visitor to hear it that ever came our way fer years after, an' when I'd come to that part about that old she-b'ar goin' out $o$ ' that stub as if a charge o' blastin' powder had been let off under her, he'd jest lay back an' laugh fit to split." 



\section{CHAPTER XIV : FAIRS OF THE PIONEERS}

FAIRS OF THE PIONEERS. THERE WAS KEEN RIVALRY IN THE FAIRS OF EARLIER DAYS. THE TOP-BOOT AND "HOMESPUN" AGE. THE FIRST MERRY-GO-ROUND WAS SLOW AND WOODEN, SUITED TO THE OX-TEAM AGE. SOME VERSES ON THE "OLD COONTRY FAIR." 



\section{CHAPTER XIV}

Fatrs of the Pioneers

$A^{S}$ soon as the pioneers of this country had any1 thing worth showing in the agricultural line, they began holding fall fairs. In the first half of last century they began and there were big yellow pumpkins, monster Swede turnips, gate-post mangel wurzels, log-cabin quilts, home-made blankets and cloths, and bread and butter in liberal quantity on display at those earliest fairs. The people of that day did not so hanker for agricultural hoss trots. You see, most of them drove or had driven oxen, and speeding up was not then considered so absolutely necessary to existence.

The fall fair of earlier days was the greatest social event of the season. That was the one day of the year when the farmer's whole family came to town and, usually in their only conveyance, the lumber wagon. The boys would be fitted out with red-topped boots on Fair Day, and the mother and her daughters would look around and see what the town folks were wearing. The whole family would. be clad in home-made clothing and, doubtless, looked healthy and happy, despite the fact that a fashion-plate had not been consulted when their wearables had been fashioned. News of changes in 
the cut of clothing or correct form of hats, boots and other necessaries of civilisation, did not travel along the concessions and sideroads with auto speed in those times.

Country folk were known by the clothing they wore and fakers had no difficulty in picking them out in a crowd. Homespun suits and top-boots made it easy work for the nut-shell men and various other nimble-fingered artists to single out the innocent, or untutored in the ways of the wicked.

\section{DOESN'T BLOW OUT THE GAS NOW}

But that is all changed in this progressive age. The man from the back concessions does not blow out the gas, and if he still retains a semblance of that innocence that obtained in the Garden of Eden, the chances are that he is, to-day, wearing more costly clothes than his town or city brother. Instead of eating buns or a home-made lunch on the street corner your young, dressed-by-thefashion-plate country gentleman hies to the classiest restaurant on Fair Day and orders up an epicurean lunch with fine abandon as to the cost.

\section{GETTING READY FOR THE FAIR}

There was, indeed, friendly rivalry among the pioneers at the annual agricultural exhibit. For weeks before, Jim, the farmer's eldest son, would be wearing out the curry-comb on the show-team; 'Jo, the second boy, would be crimping the filly's 
mane and tail and Sam, the youngest, would be prepared to put the Berkshire's tail in curl papers if necessity demanded; mother would be extra careful about the bread and butter, and the daughters of the house would be working on a rag-mat, a log-cabin quilt or a flannel shirt.

The children coming in from school would tell that Mrs. Smith over on the Tenth was going to show bread, butter, blankets and other products of the old-time farm, and the rivalry would grow and grow. It was whispered about that Bill Jones had quit ploughing as he feared the brood mare would show galls on her shoulders in the show ring, and old Sam Thomson was said to be feeding his pumpkin vines sweet milk and forcing his hoped for big yellow prize-winner to expand. Neighbours watched each other's movements very closely along about fair-time.

Young farmers in those days at the Fall Fair did not expend so much energy swinging the wooden maul at the thumping machine in order to obtain a cigar of doubtful quality, and incidentally, demonstrate how muscular they were. Instead they were to be found in crowds about the plough exhibit and other displays of farm machinery or admiring the live stock, and with critical eyes, too.

WHEN THE PLOUGH WAS THE CENTRE OF ATTRACTION

Back in earlier days more attention was given the art of turning furrows and, in order to test 
the merits of ploughs, exhibitions of the actual working of this oldest of all agricultural implements were given in the fair grounds, or in a field nearby. There was keen rivalry among the ploughmakers in those days. There were few, if any, plough factories then, and the iron ploughs everywhere in use, in that period, were the product of blacksmiths, the moulds being imported from Old Scotland. Thomas Yeandle, formerly of Stratford, Ontario, now an old man who lives at Birtle, Manitoba, was a famous ploughmaker nearly half a century ago. There is yet to be seen in an Ontario farmer's implement shed the fine iron plough which Yeandle exhibited at the Centennial Exhibition in '76 and for which he was awarded a medal and First Prize. That beautifully-fashioned implement was made on the anvil and all the product of his own handiwork, except the mould-board. At Fall Fairs, county and township ploughing matches, the merits of ploughs were the chief topics of discussion. It is a rare sight to even see a plough at a Fair in these days. Factory production has destroyed individuality in the furrow-turning implement.

\section{THE TOPPED-BOOT AGE}

Looking into the misty mirror of the past there is really not much difference between the Fall Fair of half a century ago and the modern country fall fair. There were, of course, no hoss trots then, 
fewer inflamed slumber robes, less lingerie, fewer restless tidies and stiff, severe pillow-shams and beautiful pink satin pincushions, but there were more home-made blankets, rag carpets, hand-made quilts and more bread and butter "like mother used to make."

The chief point of difference between the oldtime fair and the modern fall exhibition is really in the appearance of the folk who attend. Country folk dined on homely, but healthy and generous fare, and wore "hodden grey" in those good old times, and the men and boys wore top-boots. The top-boot period was left behind with the corduroy roads, the old ox-team and other utilities of a bygone age. But many "grey-haired boys" have fond recollections of top-boots, for the occasion when as boys, they first donned a pair of long boots was a red letter event to be long remembered. Some old-timers never got over the habit of wearing such footwear and refused to change with the fashions. One of the great American Republic's mightiest editors, Horace Greeley of "Go West, young man" fame, and who was a candidate for the presidency of his country, used to wear top-boots on Broadway, and, they say, he usually had one pantaloon leg caught up over the ear of one of the boots. It was Greeley who once said that a man never would amount to much who was always worrying about the fit of his trousers, and in this he practised what he preached. 
But to get back to this Fair subject again. In early days the farmer's younger sons usually had to drive caitle to the Fall Fair. I recall that I did so, and I remember, too, that the snake-fences along country roads were often out of condition, necessitating numerous swift flank movements to head off a sudden sally on the part of some young heifer that had hankerings to return to the home pasture-field via a cross-country route. The latchstring on the fair grounds gate was always out to a bunch of country lads driving in cattle for exhibition and it was the practice of town boys to join in with them, on occasion, and help herd the cattle through and, incidentally, get free admission. I remember that I once had the temerity to suggest to one of these only-for-a-minute cattle drivers that, for the privilege of travelling on my pass he should help me herd for a while in the fair grounds.

"Say, you rube, d'ye s'pose I'm goin' have the folks here think I'm one of you 'hawbucks'?" was the manner of his response and putting his thumb to his nose he departed. It not infrequently happened that there were fights between town and country youngsters over such incidents and a blue forget-me-not under one's eye was looked upon as a badge of courage. 


\section{THE FIRST MERRY-GO-ROUND}

I do not pretend to know who invented the merry-go-round or when it first came into use. Perhaps the ancients may have had it. The first merry-go-round I ever saw was at a Fall Fair and it was a very crude contrivance. Eight or ten wooden beams fastened with an iron pin to the top of a large post set in the ground, and the motive power was a couple of strong men who shoved the contraption around. At the end of each beam was a seat. There was no orchestrion fracturing the atmosphere with such airs as "Buy a Broom," "Linger Longer, Lou," or "When You and I Were Young, Maggie." You paid your nickel and experienced a sense of motion and dizziness for a minute or two. It was in keeping with the wooden or ox-team age, was that first merrygo-round.

They tell a story of a country young couple who were scheduled to start off on a short honeymoon tour by rail, but fell victims to the lure of the merry-go-round. They were married on Fair Day and before train time they visited the Fair. They were so enamoured with the merry-go-round that the groom, of course, with the bride's consent, spent all the intended railway fare money on this roundabout pleasure-they rode 'round and 'round all afternoon and then went back home and, well as the storybooks say-lived happy ever after. 
It was the inimitable Robert Louis Stevenson who stated that marriage is one long conversation chequered with disputes. This young couple, at least, could not very well have disputes that first ảay of their wedded life because the seats on those first merry-go-rounds were single, and so those young adventurers on the sometime troubled sea of matrimony had to sit apart.

If one were a poet the old-time Fall Fair would seem to be a worthy theme for verse. I submit the following, not as poetry, but merely as doggerel. Of course, such explanation is unnecessary, the discerning reader may perhaps remark that, even as doggerel, the lines are unworthy.

\section{THE OLD COUNTY FAIR}

Through days o' scorchin' summer heat, an' through showers o' drenchin' wet,

We've wrestled with the hay an' grain an' much success we've met,

An' we're feelin' right up on the bit, for we know we've done our share

To uphold the farmers' glory in our county's big Fall Fair.

Jim has brought his plough team, an' Sam has brought his pig,

Joe has a steppin' two-year-old hooked to our bran' new rig,

I have a pair of pigeons an' a crowin' bantam rooster, And this big Fall Fair of ours, why, we're all prepared to boost 'er. 


\section{Fairs of the Pioneers}

Mother's brought preserves and things, they stand upon a shelf,

There's a big red ticket on 'em, and our M.P. hisself Took a taste, an' then another, then he broke into a smile, Then he said, "Why, Mrs. Jones, you've got 'em beaten by a mile."

In the Art hall where the ladies go to hang their fancywork,

Sister's "showin" " brings folks to a standstill with a jerk;

A log-cabin quilt, a rag-mat an' some wearin' things with frillin',

An' the folks around say sister's work is-well, jest simply killin'.

Down among the pens an' stables where they show the cows an' sheep,

Dad's got a brindle heifer that's the sleekest $o^{\prime}$ the heap,

An' he's winner of a "special" prize for his colt shown on the line,

An' that rooster ye hear crowin' in the poultry-house is mine.

You may shout about Toronto and the big Western Fair,

With their fountains and big buildin's and men flyin' in the air,

But I'll bet my bantam rooster, 'gainst a quarter, if you dare,

That there's not one-two-three in it, with our old county fair. 



\section{CHAPTER XV: SCHOOLS OF THE THREE "R'S"}

THE LOG SCHOOLS OF THE PIONEERS WHEN THE THREE "R'S" ONLY WERE TAUGHT. A SCHOOL ON THE BANKS OF THE AVON WHERE ONE OF CANADA'S GREAT MEN WAS A TEACHER. INCIDENTS GRAVE AND GAY IN THE RURAL HALIS OF LEARNING. A CLEVER BOY AND A KNOT-HOLE IN THE SCHOOL FLOOR. THE OLD SCHOOL EXHIBITION. 



\section{CHAPTER XV}

\section{Schools of THe Three "R's"}

I remember, I remember, the log school by the Creek, Where first we got book l'arnin'. There was me an' Tom an' Dick. An' Mary Jones an' Nancy, and Old Si 'Thomson's gal, An' the dominie, but nowadays they call him principal.

I remember, I remember, all about those blue-beech switches, An' how that teacher, oftentimes, would dust our little breeches. An' how I tangled hopelessly in the long division rule, An' wore the cap that told the class I was something of a fool.

WOULD that I had a magic pen that I might produce a "living likeness" of the country school and the group of happy girls and boys that once I knew.

If it were only twenty years ago, but ah me, it's forty, and many of those cheery faces have vanished quite.

I have a feeling akin to the poet who wrote:

". Have you seen those girls and boys

That but a little while ago, made oh, such pleasant noise,

0 , trees and hills, and brooks, and lanes, and meadows, do you know

Where I shall find my little friends of forty years ago?

You see I'm old and weary, and I've travelled long and far;

I am looking for my playmates-I wonder where they are." 
In such a collection of memories as are set forth in this volume ranging far and wide it would, indeed, be a grave omission if mention were not made of the country schools of other days. Most great men in this lately out-of-the-woods land had their first introduction to "book l'arnin" "in a little log school-house.

I missed the log seat of learning by several years, perhaps that may be the reason why I have never achieved greatness or had it thrust upon me. But the log school-house was still standing in the school-yard, and was used as a woodshed, when I set out on the path towards an education. You'll observe, then, that I missed the first qualification to greatness by a narrow margin.

\section{HOPED TO "LICK" THE TEACHER}

Most "grey-haired boys" have kindly recollections of their alma mater, but I have known schoolboys whose chief desire was that when they had grown to manhood they would have developed brawn enough to enable them to "lick" the teacher. I believe that I had hankerings mysclf in that direction in my hot youth. But, of course, all such vain and inglorious longings had faded away by the time the age of young manhood had been reached and with the larger vision, came respect, yes, reverence, for him who had been engaged in the task of directing young ideas how to sprout, branch out and develop a manly, healthy growth. 
PIONEER SCHOOL-HOUSES

The pioneer school-houses of this wooded country were nearly all $\log$ buildings-same as the homes of the pioneers. There were no blue-print plans prepared, showing front and rear elevations, to guide the workmen - the man with the axe was both architect and builder. But within these crude "halls of learning," first aid to the untutored was dispensed by the teaching of the three $R$ 's-readin', 'ritin' and 'rithmetic, or cipherin', as that last " $R$ " was sometimes designated.

One room, with four rough log walls and, likely, a trough roof, sheltered the little band of homespun-clad knowledge-seekers. A rude fireplace gave forth the necessary warmth and the scholars quenched their thirst at a bubbling spring at the base of a nearby hill. Blazed trails through the woods guided those pioneer scholars to the "noisy mansion."

Such scholastic facilities existed only in the very early days of our civilisation, for the pioneer was no laggard in matters of education. He saw to it that the evolution of the country school kept pace with the development of the district in which it might be located.

FATHER OF CHEESE INDUSTRY A TEACHER

Oh, that kodaks had been in vogue in those days that pictures of those very first schools, inside and 
out, might have been preserved! I have in my mind's eye only an imperfect reproduction of that rude little $\log$ structure--the first school-house in the section where I was born. It was falling to decay when I first saw it, but I have pleasure in recalling that one of Canada's great men imparted knowledge within its walls. The late Hon. Thomas Ballantyne, the founder of one of Canada's most important branches of agriculture-the cheese industry-was a teacher there. The teachers of those days had to depend largely on their storedup knowledge, for the text-books extant then, were far, far different from those in use in these modern times. But those pioneer teachers left the imprint of their personality upon the scholars in a way that is now almost a lost art.

\section{AN OLD SCHOOI READER}

In reference to early text-books I have on my bookshelf an old, musty, dog-eared, leather-covered Reader, that my father learned to read from in a $\log$ cabin situated on the banks of Avon in 1835. The title-page reads, "A collection of English prose and verse for the use of schools, selected from different authors; to which are prefixed a few short lessons for beginners with an exercise on spelling, in four large tables containing all the words of three syllables and above, a great many of three and two and the proper names divided and accented. Also an appendix containing prin- 
ciples of English grammar, by Alexander Barrie, teacher of English, Writers' Court, Edinburgh."

The volume bears the imprint of the publishers, Murray \& Mitchell, Edinburgh, the date, 1832, and has a quotation from the Scottish poet, James Thomson, who wrote "The Seasons," "The Castle of Indolence" and other poems worth reading.

The quotation, I presume, was intended to reconcile the teachers to their lot. It runs:

"Delightful task! To rear the tender thought,

To teach the young idea how to shoot,

To pour the fresh instruction o'er the mind,

To breathe th' enliv'ning spirit, and to fix

The generous purpose in the glowing breast."

\section{NOT A SMILE IN THE WHOLE BOOK}

I do not know if "Jimmy" Thomson ever taught school but, at all events, he had lofty ideals for those in that profession.

Looking over the old Reader in which the "f $f$ 's" and "s's" are in the same character, I fail to find a line of brightness-nothing in lighter vein, nothing that would conjure up a smile, but the same seriousness throughout as prevails in the Shorter Catechism.

But, of course, it was compiled by a God-fearing, sober, dour, melancholy Scot, in the days when it was customary in Edinburgh, to draw the blinds down tightly on Sunday and when to laugh on the "Sawbath" Day was a crime. 
Think of a "Reader for Beginners" with such themes as are contained in the following: A Thought on Eternity-An Elegy on EveningMidnight Thought-Reflection on the Death of a Profligate-Swearing-Temperance-Lying-A Funeral Thought-Virtue under AfflictionGray's Elegy-An Essay on Sleep-Extracts from the Works of Milton, Addison, Blair and other serious writers of the past.

Somehow or other the compiler missed Blair's poem on "The Grave," and how he must have grieved over it when he noticed the omission.

Turning to the appendix on English Grammar, I feel that we moderns have not improved on the definition of "What is English Grammar?" It is defined in this old book as "the art of speaking or writing the English language with propriety." That's good, is it not, that "with propriety"? And that definition was the first line in the grammar. To-day they lead the youngster into the complexities, mysteries and sinuosities of English as it is spoken or written in a simpler, if more deceptive, manner.

\section{SOAKED UP INFORMATION AND WATER}

I began my educational career in a stone schoolhouse built on a hillside overlooking the classic stream, Avon. I mention the stream, for beside allowing hard words and other information to soak into my system in my school days, I recall 


\section{Schools of the Three " $R$ 's"}

that my elothing soaked up a good deal of that river water-I was an inveterate wader as a small boy, and the water of the Avon in those days was not so full of sewage that it could not be soaked up readily.

\section{BLUE-BEECH GADS}

The school was a one-roomed building with a windowless lobby across the front. A big boxstove stood in an opening in the partition between lobby and schoolroom, and a crazy and irregular set of stove-pipes extended along the full length of the ceiling. I recall that a number of boy scholars were told off each day to carry in the wood, similarly, certain of the girl scholars had to remain after four o'clock to do the sweeping and, thus, incidentally, had lessons in husbandry and housekeeping.

One promoter of school discipline kept a generous supply of black-birch and blue-beech gads fastened to the wire by which the stove-pipes were kept in place. He used to wear out the aforesaid foliage, for what seemed to us youngsters, very slight and unimportant violations of the rules. I may state that the woods about the school stood ready to furnish an unlimited supply of gads, suitable for earrying out the scriptural injunction regarding the rod and the spoiled child.

Scholars of earlier days at country schools, will remember that the different classes used to 
be called up for lessons to the front of the school, and were arranged, or placed, according to merit. The head of the class was known as Number One and it was customary for the class to "number off" after each lesson. There was keen rivalry, of course, as to who could gain and maintain the place of honour.

\section{KEPT HIS TOE IN A KNOT-HOLE}

They tell a story about a boy who persistently stood at the head of the class despite all efforts to dislodge him. The school floor was of rough lumber and had numerous knot-holes in it. It was noticed by a rival that this boy always stuck his big toe into a knot-hole in the floor, where he stood and held the fort against all comers. That knothole had become a habit with him. With his toe in that hole he could solve knotty problems and spell with ease all the large and difficult words thrown in his direction. His envious rival stole into the school-house one dark night and hammered a piece of wood into the knot-hole and looked for results next day. They came. When the class was called that steering-by-the-knot-hole student got mixed. He couldn't get his toe into the accustomed place and thus refresh his memory and the tow-headed scamp who had plugged the hole displaced him. 


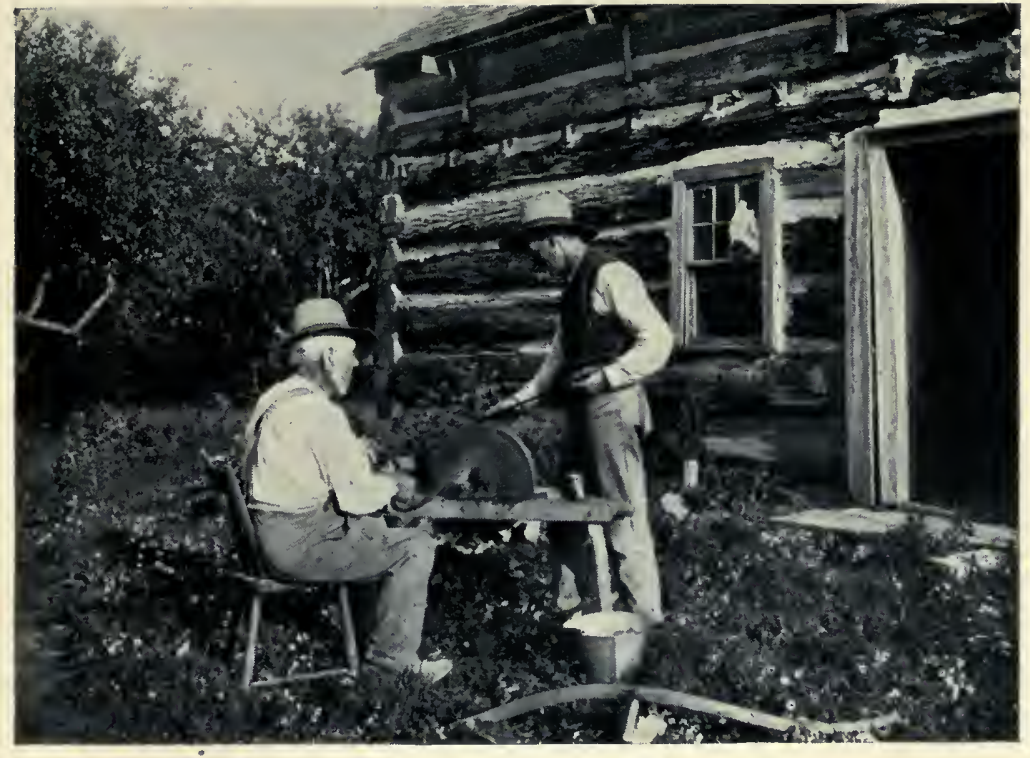

GETTING READY FOR THE HAYING. 



\section{A CLASS INCIDENT}

John Greenleaf Whittier, the Quaker poet, who has left behind many exquisitely beautiful poems, never penned anything more sweetly pathetic than his verses descriptive of a class incident, commemorative of his own schoolboy days. I quote the poem in part:

"Long years ago a winter sun Shone over it at setting; Lit up its western window panes And low eaves' icy fretting.

"It touched the tangled golden curls, And brown eyes full of grieving Of one who still her steps delayed When all the school were leaving.

"For near her stood the little boy Her childish favour singled;

His cap pulled low upon a face Where pride and shame were mingled.

"Pushing with restless feet the snow To right and left he lingered, As restlessly her tiny hands The blue-checked apron fingered.

"He saw her lift her eyes; he felt The soft hand's light caressing, And heard the tremble of a voice As if a fault confessing.

" 'I'm sorry that I spelt the word; I hate to go above you, 
Because'-the brown eyes lower fell-

'Because, you see, I love you.'

"Still memory to a grey-haired man

That sweet child-face is showing,

Dear girl, the grasses on her grave

Have forty years been growing.

"He lives to learn, in life's hard school

How few who pass above him

Lament their triumph and his loss

Like her-because they love him."

BAREFOOTED BOYS AT SCHOOL

Country school children during the summer season in those good old days did not wear shoes, and the boy who came the earliest in the spring without his footwear was looked upon as a hero and was the envy of his fellows. The teacher, of course, had his eye open to check any undue rushing of the season in the matter of bare feet. It may be added, too, that the schoolboy who could not show a stone bruise on his heel in the good old summertime, lost caste in the eyes of his companion, and was surely termed a "sissy."

\section{ABOUT THE SCHOOL STOVE}

I have distinct recollections regarding the imperfect heating of a pioneer school. The big box stove would be fed to capacity and, with dampers wide open, would roar like a blast furnace in 
miniature. About the stove the heat would be intense, but the unfortunates whose benches were near the walls, often shivered. A kind-hearted teacher-and most of them were so-used to send us in detachments to benches, by the stove, on very cold days. Rubbers and overshoes were not then worn and our cowhide red-topped boots were usually either damp or frozen stiff.

The contents of our ink bottles-small stone ones in those days- - would be frozen solid at night, and, before the hour for writing, there would be a procession to the stove to thaw out the writing fluid. The ceiling above that stove had as many spots on it as a whole web of polka dot fabric. It was a common occurrence-sometimes by accident but mostly by design-that a youngster would leave his ink bottle to warm up, with the cork tightly driven in. When the steam pressure got high enough a cork would hit the ceiling and a fountain of ink usually followed it.

It was Lord Byron who wrote:

\section{"A small drop of ink}

Falling like dew upon a thought, produces

That which makes thousands, perhaps millions, think."

This ink that I am writing about fell like raindrops and made us youngsters wink, instead of think, when we got the shower upon our upturned faces. 


\section{DULLNESS AT FIGURES A SIGN OF GENIUS}

I was always dull at figures and I recall that my dearest schoolboy friend was so afflicted. We were indeed, far, far from being human adding machines. Some say it's a sign of genius, but I never knew a teacher who was willing to recognise that theory as truth. Our teacher termed such a condition, dullness or stupidity, and we two frequently wore the "Dunce's Cap," a long, cornucopia-shaped affair with the word, "Dunce," in big black letters across the front. I knew a farmer, in other days, who used to say, regarding his son, that it was never safe to send him to town with a load of wheat unless the price was an even dollar. My chum and I were almost in that class in so far as "cipherin", was concerned. And I have to admit, too, that I have never gotten over a faculty that developed in me in early lifethat of mutilating the English language without hesitation. I believe there are many people so afflicted.

But what cared we for the "Dunce's Cap"? Cares sat lightly indeed, on our schoolboy brows. All the troubles that infested our lesson hours were forgotten when school was dismissed, and, carefree, we cut all the capers and played the games of happy childhood.

In those good old school days the copy-book head-lines were all written in by the teacher and, in the very early days, with a quill pen. Beside 
writing in the head-lines the teacher had to mend the pens. And what "grey-haired boy" of today but has carried along in mind with him on his pilgrimage, the nuggets of wisdom as set forth on the head-lines of those copy-books. The frequent repetition by writing whole pages of such choice chunks of sage philosophy engraved them indelibly on the films of the brain.

Here are a few of those old head-lines that I am able to conjure up from the abyss of the past.

A soft answer turneth away wrath.

Be not overcome of evil but overcome evil with good.

Better to get wisdom than gold.

Contentment is better than riches.

Cease to do evil, learn to do good.

\section{A LEFT-HANDER LEARNING TO WRITE}

Being left-handed I recall that learning to write was a sore trial for me. The teacher absolutely forbade the use of my left hand in that connection and, during the writing hour, he used to walk up and down the aisles, armed with a wooden pointer. It is next to impossible to write and keep one's eye on the teacher, too. I tried and I know. Stealing up softly on me from behind I felt the weight of that pointer wielded by the teacher, on my poor left hand on many occasions. At this distance of time, I thank him, but I am rather proud that I am able to boast, despite his 
argus-eyed watchfulness, that $I$ am ambidextrous as a writer-that is, I can write with both hands.

In other days I think it was held that using the left hand was just "pure cussedness," or crass contrariness, but physiologists have shown that the brain cells have all to do with this desire to use the left or right hand. In a left-handed person the motor area is on the right side of the head and in a right-handed one on the left side. Old nature does some peculiar stunts and this may be classed as an example. Medical men do not know why this condition should be but they do know it exists. By constant and persistent use of the right hand a born left-hander may, in a measure, develop the brain function necessary to perform certain muscular actions but he cannot entirely overcome the desire or impulse to use his left hand.

\section{GAMES AND SPORTS}

Even in those far-off days most country schools had baseball teams, and I remember that our teacher took a hand in our games on the school ground and occasionally lammed the ball into a neighbouring grain-field, causing long interruptions while the spheroid was being recovered. That an indignant farmer at times offered strenuous objections to our romping about in his growing grain to find the lost ball, was of trifling import.

In the winter season, at the noon-day intermis- 
sion, when the teacher was absent at his boardinghouse on a neighbouring farm, there were lively doings in the schoolroom.

After lunch from their little baskets had been disposed of, there often were games played in which boys and girls joined, and, not infrequently, games which called for forfeits and kisses. These tried the bravery of the boys, and the modesty of the girls was put to a severe test. Sometimes a little maid would scratch and scream rather than submit to the ordeal or cover her face with her pinafore or apron which were worn as decorations in those happy days. If she were fond of the boy on whom the lot had fallen to salute her with a kiss, it would all be over in a second. It was against custom to be strenuous or forceful in pursuing the girls to exact tribute. Mostly the sweet maids consented, without demur, and so made light of the ceremony.

As a part of the kissing game a song was sung by the participants and the psychological moment was when the words,

\section{"There's a rosy in the garden \\ For you, young man,"}

was chanted.

Then the edict:

"Your girl is in the garden, Go, kiss her like a man."

Shy but expectant glances on the part of the maid 
and ofttimes confusion on the part of the boy were in order at this juncture.

The song was sometimes varied into

$$
\text { "Your Love is in the garden," etc., }
$$

and the garden was wherever the girl happened to be or where she could be caught.

If the "movie" picture men could reproduce one of those school kissing games, just as it was played in pioneer days, with all its joyousness, delicacy and animation, they'd have a fascinating film.

I have in mind several girls who had a penchant for "cancelling" on their slates, the names of the handsomest of their boy friends in conjunction with their own. The result of the cancellation of similar letters in the names of a couple was believed by the schoolgirls of those days, to be a reasonably sure indication of the destiny of their lives from a matrimonial point of view. Whether the horoscopes then cast ever proved correct in the case of these young innocents, likely, they themselves alone know. It was said, too, that certain of the boys sometimes dealt in such alphabetical prospectives. Perhaps the chap who conjured up the following apparition in verse was one of these:

"When the golden days of autumn

Cloud the hills in smoky haze, And life to us seems dearer For the shortness of the days, 
Floats a lovely apparition

'Fore the mirror of my eyes,

And I think of one, ah, long since gone

To mansions in the skies-

A sweet-faced maid was she, indeed,

Whose slightest wish, my rule-

$\mathrm{Ah}$, those are the days I'm thinking

Of the girl I loved at school."

And it may also be that the woman who penned these verses had in mind the boy whose name "cancelled" with hers most felicitously:

"When I get to thinking back Upon the days of long ago, And from memory having visions Of the boys I used to know, Comes the saddening reflection Passing years may not o'er-rule, Of my lost love-a dear, dear boy, Who was in my class at school."

\section{EXAMINATION DAY}

Who, among us, who were so fortunate as to have been educated at a country school but has vivid recollections of "Examination Day." Such an event was usually held in December just before the Christmas holidays. For such occasion the schoolroom would be cleaned with meticulous care and frequently was decorated with evergreens and tissue-paper flowers. Parents and grown-up sisters and brothers of the scholars would be invited to come and admire them in their 
best attire, and discover how clever they were. Of course there would be a programme of dialogues and recitations. Some of the real clever ones would have to "say a piece," that is give a recitation. Some of us never get beyond "saying a piece" and, sometimes, when one has to listen to certain long-winded abstractions in the forms of addresses or lectures one wishes there had been fewer graduates in oratory.

With infinite pains for weeks before the teacher would preside at rehearsals that "Our School Exhibition" might be a success. Many an oratorical spell-binder got his first aid to the art of public speaking at these school Exhibitions and it is a matter for some regret that they are now as a tale that is told.

“But these 'Old School Exhibitions' they've departed evermore,

The log school-house is deserted and the weeds have blocked the door,

Breezes sweep around its corners, with a low and sorrowing whine

For the old boys 'born at Bingen-at Bingen on the Rhine."

One can imagine with what pride those fond parents of other days beheld the evidence of hopedfor greatness in their boys and girls on Examination Day. Alas, that so many of us should fail to fulfil the promises of youth! Often when one gets a-wandering back in memory to other days- 


\section{Schools of the Three "R's"}

school-boy days-one wonders what became of the clever boys, those who were always at or near the head of the class, and who won all the prizes. Have they become the leaders of men in life's battle or did they, starting out strong, lag behind in the race?

"Tom Brown was my dearest chum, in my old class at school,

To whom everything came easy, e'en the long division rule;

Girls always thought him handsome, and a smart and knowing boy,

An' his parents on his future looked with only pride and joy;

'Tother day I ran across him-first time in these thirty years-

Ho was loafin' 'bout the country sharpenin' butcher knives and shears."

I omitted to state when I made reference to the fact that we wore our "best clothes" on Examination Day, that most of us were dressed in homespun. Our fathers kept sheep and the wool was carded for spinning at home or at the woollen mill; it was spun into yarn by our mothers or sisters and made into cloth or homespun at the mill. There were, at that time, hand looms in many farm homes throughout the land.

Tribute is due the thrifty wives and daughters of the pioneers for the excellent manner in which they looked after the wearing apparel of their households. Sewing machines were a rarity but 
these brave womenfolk never faltered at their task of producing the family clothing. Many a "greyhaired boy," to-day, thinks lovingly back, as I do, to the days when he wore a suit that mother made. Skill with the needle was one of the finest accomplishments that these pioneer women held dear.

At these country school examinations it was customary for the trustees to furnish prizes and these were usually presented by a minister who always said a few kind words of praise or advice to the clever scholar. I recall that $I$ once won a prize and was given a copy of Paley's "Natural Theology," about as dry a piece of literature as it is possible to imagine for a grown-up-fancy the joy it brought to a boy of twelve. The donor expressed the hope that I might some day be a great divine, like Paley, and I found myself sorrowing that the minister had not hoped that I would turn out an adventurer or a pirate instead, and had given me a book to encourage me in such a career.

\section{SPELLING BEES}

"I wasn't much at grammar,

I wasn't much at cipherin',

At readin' I would stammer

My l'arnin' mostly triflin'-

'Cept spellin'-thar I came out strong,

I'd spell an' spell the hull day long."

Most country schools over fifty years back, had spelling bees or classes every Friday afternoon. 
A girl and a boy were selected as captains and then the picking and choosing began until there was a row along each side of the schoolroom. A medal, usually a small silver one, in the form of a small shield with a ribbon to suspend it from the neck of the winner, would be furnished the school, and there was great rivalry for its possession. I am hazy on some of the events of schoolboy days, but I can still remember the name of the girl who spelled the whole school down on several occasions. The teacher gave out the words and as one failed to spell a word correctly it was given across to the opposing side. Those who misspelled went to their seats. Darwin's theory of the survival of the fittest was worked out before our eyes in those spelling matches. There would be words handed out that twisted and crawled like serpents-disyllables, trisyllables and polysyllables in all the complicated forms that the English alphabet may be contorted into. Then there was the grand finale of applause when the winner, usually a girl, went forward and the teacher tied that blue ribbon with the medal about her neck.

Grammar was mostly rules as I remember it. I had a horror of the very word. Those dreadful lengthy rules, those confusing parts of speech and the mournful parsing seemed to my schoolboy senses a gibberish gabbled in some unknown country for some not understandable purpose. Measles broke out in the section and the word as well as the disease was the subject of much discus- 
sion among the scholars. One boy who always tripped on the study of grammar argued that measles was plural because so many folks had it. Another argument he advanced in favour of his point was that "measles" like "molasses" was plural on account of the "muchness of the s's."

\section{CIRCULATING LIBRARIES}

In the days of which I write there were circulating libraries in some country schools, but not for the scholars, oh, no. A few erudite bodies-there were those in most neighbourhoods in early days -would meet on Saturday afternoons to exchange books, which were usually kept in wooden cupboards in the schoolrooms. The particular school library I have in mind was presided over by the late John Caven, father of Principal Caven who made Knox College, Toronto, famous.

$\mathrm{Oh}$, but they were fine books that those "greyheaded boys" read-Carlyle's "French Revolution," Shakespeare, John Galt's "Annals of a Parish" and likely Paley's "Natural Theology" and Hugh Miller's works, surely, were in that cupboard. I feel that I held fast to my maternal grandfather's hand one fateful Saturday afternoon when I was introduced to that intellectual circle. I remember that Mr. Caven thrust a big book into my hand, with the request that I find a seat and enjoy (?) myself while he and his confrères held their weekly chat. I would not state it, 
positively, at this distance that some of these fine old gentlemen desecrated the sanctity of the hall of learning by burning incense in the form of tobacco in clay pipes, but I am reasonably sure it is true. Peace to their ashes and may some small boy of to-day think of me as kindly in years to come as I do now of them.

The big book that Mr. Caven handed me was a collection of Shakespeare's tragedies finely illustrated with steel engravings and I gazed and gazed spellbound at the picture of that hump-backed King Richard the Third, slaying Richmonds by the half-dozen in that history-making contest on Bosworth Field.

If there is one subject that literary men and women love to write on it is about their schooldays. Many of the great writers, and lesser ones, too, in both poetry and prose, have set down loving, kindly thoughts on this theme. There are poems by the hundred on the school and schooldays and many of them exquisitely tender and beautiful.

Thomas Dunn English, in that pathetic old song "Ben Bolt" which George Du Maurier used with such fine effect in his book "Trilby," did not forget the school, although his reference to his teacher seems unkind. One of the verses runs thus :

"And don't you remember the school, Ben Bolt,

With the master so cruel and grim, And the shaded nook by the running brook,

Where the children went to swim? 
"Grass grows on the master's grave, Ben Bolt, The spring of the brook is dry,

And of all the boys who were schoolmates then, There are only you and I."

For "grey-haired boys" and girls, too, it is, indeed, a far cry back to those dear days of childhood when they acquired their first "book l'arnin" "and few there be, it is hoped, who through the mist of the years when they indulge in "thinking back," but are able to conjure up pleasurable memories. 


\section{CHAPTER XVI: SONGS OF OTHER DAYS}

SONGS OF OTHER DAYS THAT WERE SUNG BY THE FARMER'S FIRESIDE. SOME OLD-TIME SONGS RECALLED. THE FIDDLE, THE KING OF MUSICAL INSTRUMENTS. THE GOOD OLD FIDDLER AND HIS POPULARITY. 



\section{CHAPTER XVI}

\section{Songs of Other Days}

IN this "Old Days on the Farm" volume I have 1 already referred at some length to the singing school, and the old organ in the farmhouse parlour. Of course, music was not confined alone to these on the old-time farm. It might not be amiss to set down something of the songs of that period. These were not so numerous as in this day of popular concerts and gramophones but they lasted longer. At country festive occasions-then, oftentimes, between the dances, it was not unusual for some sweet-voiced maid or lusty-throated young farmer to sing a song, and without an accompaniment, too. The old folks, in particular, enjoyed that part of an evening's gaiety.

In the '60's and '70's this Canada of ours was flooded with American war songs. Some of these were "Tenting on the Old Camp Ground," "The Faded Coat of Blue," "Just Before the Battle, Mother," "The Vacant Chair" and others that had drifted northward, were often sung in Canadian homes. . The annual visit of the circus usually left behind, as an aftermath, a song or two right from Old New York. The plantation melo- 
dies of the Sunny South were always popular here and likely will be for many æons to come.

SONGS BY THE FARMER'S FIRESIDE

When I was a small boy I recollect that my father had a couple of retired soldiers in his employ from one of the regiments disbanded in this country in the '60's. They were Irishmen and wended their way through the English language with a fine brogue. By the fireside in the evening it was a delightful treat, to the youngsters of our family, to listen to the songs of those light-hearted boys from Erin's Isle. One used to trill out, and with just the proper accent, too, that old Irish ballad, "Pat Hagerty's Leather Breeches." The song begins thus:

\section{"At the sign of the bell, on the road to Clonmel,}

Pat Hagerty kept a nate shabeen;

He sold pig's meat and bread, and had a fine lodgin' bed,

And was liked in the country he lived in.

Himself and his wife they struggled through life,

On week-days Pat mended the ditches,

But on Sunday he dressed in a coat of the best,

But his pride was his old leather breeches."

The song ran through many verses and told the tale of what happened to those breeches. For want of meat, Paddy, on one occasion, when his lodging-house was invaded by a roystering crew 
in the dead of night, found it necessary to stew his breeches and they were served up as tripe. A tragedy almost occurred when one of the roysterers held up on the end of his fork a big ivory button. Pat and his loving wife Judy, made a quick getaway to the bogs.

I am carrying about on the tablets of my mind every verse of that old song-and I recall verses of another those soldiers sang which ran:

"Last night I lay dreamin', Bad 'cess to my dreamin',

I'd die if I thought 'twould come truly to pass;

I dreamt as the tears o'er my pillow was streamin', That Teddy had courted another fair lass, And when I awoke wid the wealin' an' wailin', The thought of my sorrow 'twas hard to conceal, Me mother said, 'Norah lass, what is your ailin'?' An' all $\mathrm{I}$ could answer was, 'Teddy O'Neil.' "'

\section{PLEASURE AND SADNESS IN OLD SONGS}

These and many others, long since forgotten, these jovial Irish iads sang by our fireside. A thrill of mingled pleasure and sadness in the hearts of some elderly readers may be occasioned by mere mention of the songs of the past, because there is nothing that will so carry the memory back to happier and more sorrowful days than echoes of songs that have been sung or listened'to.

One often hears some one say, "I remember the night I first heard that song." It sets one 
"thinking back" as nothing else will, to hear an old song and it may be as Shelley said, "Our sweetest songs are those that tell of saddest thought."

It is noteworthy that many of the songs of earlier days were pitched in a mournful key and often invited attention to death and the grave.

\section{SOME OLD FAVOURITES}

There was that pathetic ballad of "Gentle Annie," the refrain of which ran:

\section{"Shall I never more behold thee?}

Never hear thy winning voice again? Thou wilt come no more, Gentle Annie, When the wild flowers blossom o'er the plain."

And "Annie Lisle," the words of which are no longer heard, although the Salvation Army keeps the tune alive. The refrain of this ran:

"Wave willows, murmur water, Golden sunbeams smile, Earthly music cannot waken Lovely Annie Lisle."

"Rosalie, the Prairie Flower" was another oldtime favourite full of sadness:

"On the distant prairie, when the heather wild In its quiet beauty lived and smiled, Stands a little cottage and a creeping vine Loves around its porch to climb. 
"Fair as a lily, joyous and free,

Light of that prairie home was she,

Every one who knew her felt the gentle power

Of Rosalie, the prairie flower."

As was usual with the sentimental song-heroines of that day, Rosalie died and was buried in the final verse of the song.

Another favourite that I recall was "My Blueeyed Bonnie Eloise." This came from the big Republic to the South, too. I can only recall the opening verse and I feel that I may be "mixed" on it.

"Oh, sweet is the vale, where the Mohawk gently glides, On its clear winding way to the sea,

But fairer than all storied streams on earth to me Is the Belle of the Mohawk Isle."

The negro melodies of Stephen Collins Foster and the Jacobite ballads of Bonnie Scotland were, of course, often sung and were always popular.

\section{THE OLD-TIME FIDDLE}

In pioneer days about the only musical instrument to be found in the old farmhouse was the violin-or rather, the fiddle.

And speaking about fiddling, dear reader, did you ever think when listening to such music that it was the joint production of a cat and a horse and a man or woman. You didn't, eh? Well, here's a little verselet that will set you ruminating: 
"A noise arose in the orchestra As the leader drew across The intestines of the agile cat, The tail of the noble horse."

I always feel that any man that has music enough in his soul to whistle or lilt a "coon" song and even out of tune, must find his heart strings tremble and vibrate when the aforesaid parts of the cat and horse, mentioned above, meet together in unison. The fine old fiddler, the joyous squeaking fiddler, the prideful, perspiration bedewed fiddler, the fiddle-till-you-drop-to-the-floor fiddler, is getting rarer every year but there are still some of his kind on the frontiers of civilisation-on the lone prairies, in the deep lumber woods and at the mines, in the forecastles of ships and well-on the back concessions. In all the outof-the-way and therefore, fortunate and original places the fiddle is still the best-beloved instrument of music and the skilled and enthusiastic fiddler is always sure of applause and such tribute as may be afforded.

\section{WERE CHEERED BY THE FIDDLE}

Oh, yes, the mighty youth of early days in this broad Dominion were cheered by the fiddle. The humble cabin of the pioneer in the long, lonely winter nights was enlivened with its strains. It was the life of merry-making in the days of the 
logging-bee, the clearing, the cowbell and the bushplace. Everybody loved its music.

\section{POETS AND VIOLINS}

Most every one is familiar with that little poem of James Whitcomb Riley's on "The Fiddle."

And Mr. Riley was not the only writing man who paid tribute in verse to the fiddle. There have been many fine short poems about this king of musical instruments. Boys and girls, born and raised in the country, where'er they may be, find their thoughts turning to the happy days of childhood whenever they hear its strains.

" 'Mid strenuous strife of city life,

I look back to boyhood days,

With many a sigh for the days gone by

Since I walked 'mid country ways.

Ah, rare delights of those winter nights,

When free from care and sin,

By the kitchen fire we'd never tire

Of the tunes on the violin."

\section{THE FIDDLER A MIGHTY POPULAR MAN}

They used to say in a rural community that the youth with a good 'coon-hunting dog in the falltime was likely to be the most popular person in the district. It was just nonsense. Why, as I knew it, the fiddler was an easy first against allcomers. "Is the fiddler here yet?" would be the 
first question the young folks would ask one another when they gathered for a dance at a neighbour's home.

"Not here yet, my gracious, hope he won't disappoint us," I think I hear Marthy Ellen say.

What an anxious time it was if he came late. And talk about a welcome guest. When Si came in with the fiddle wrapped in an old shawl the boys would take it from him as carefully as they'd handle a baby, and the girls would lead him to the warmest place at the fire and actually hold his hands in theirs to take the chill out of them.

The sound of tuning and scraping the prelude to the melodious outburst of "Money Musk," "The Arkansaw Traveller," or some other fine old classic would bring everybody to their feet.

There were some terribly violent dancers in those pioneer days and I've seen with my own eyes a full bucket of dust swept up from a floor the morning after a "hoedown." The dust was ground wood which the nails in the dancers' boots had worn off the floor. It was not because the boys were not light-footed or light-hearted then, but for the reason that boot soles were nailed on and that reels and jigs were in high favour.

There have been great men-great Canadianswho loved the fiddle, maybe I should use the word violin. Sir John A. Macdonald loved violin music and Alex McKenzie was fond of a Scotch reel danced to its music. There is a legend to the effect that a member of one of our first Legislative 
bodies fiddled his way into parliament. He wasn't much on oratory, but he could fiddle a little better than any man in his county, and so they sent him to parliament.

To-day nearly every farmhouse has a piano or organ or gramophone but this king of all musical instruments is not so much in evidence as it once was, and more's the pity that it should be so.

A poet of the olden days writing of the long winters on the farm, ended up some verses on the subject in this way:

"What's the use of whinin"

All the winter through,

'Cause the sun ain't shinin'

Like it used to do?

Ain't we got the fiddle,

Full of old delights,

Sashayin' down the middle

Of the winter nights." 



\section{CHAPTER XVII: OLD WELLS}

OLD WELLS ON THE FARM. LOCATING HIDDEN SPRINGS WITH A FORKED STICK. THE BIGGEST DOG AND 'COON FIGHT THAT EVER TOOK PLACE, THE SCENE, THE BOTTOM OF AN OLD WELL. 



\section{CHAPTER XVII}

\section{OLD WELLS}

$\mathrm{N}$ the early days on the farm the settler who was I so fortunate as to have had a bubbling spring of water was likely envied by his less favoured neighbours. Hilly and gravelly farms, those along streams or rivers usually had springs, where good drinking water for man or beast could be had without effort. But there were many farms that were not well-watered, and wells had to be dug. In those good old days wells were stoned up, that is, the sides were walled up with field stones, consequently the shafts sunk into Mother Earth had to be made large to admit the stoning up process.

It was a stout job to dig a well six or seven feet in diameter and, perhaps thirty, forty or fifty feet deep. Dry wells were not uncommon and it must have been real disappointing to sink such a shaft and fail to get water.

FINDING WATER WITH A FORKED STICK

Was it any wonder then that in the days of the digging of such wells, the farmer turned to the "water-finder" or "dowser," to locate a hidden spring before starting to sink a well? Talk to the 
average man about the water-finding art and he'd reply right quick: "It's all bosh, there's nothing to it!"

But there are others who hold affirmative views and I'm one of these. As a small boy I watched an old grey-bearded man work the forked stick on several occasions with marked success. On a high and dry farm, near my home, several wells had been dug, but failed to give water, and the services of the water-finder were at length engaged. A few yards from the corner of the farmhouse the old man stopped after frequent criss-crossing of directions.

"Right here, Henry, you'll find a mighty strong spring at about twenty or twenty-four feet," said the old man. And Henry did. I was right on the spot watching the digging operations and at a little over twenty feet an underground stream was struck that flowed water like a fire-hose under eighty-pound pressure, and it filled that well clear to the top. I was converted to a belief in wellfinding right there and I've remained converted ever since.

Just luck, you say, that he found that fine flowing spring. Well, have it your own way but you can't get Henry or I to change our views. Henry, you see, had dug those several dry holes and I saw him working at them.

I've heard the unfaithful say, "Why, those old chaps just found out, somehow, about where a man wanted a well on his farm and wiggled the stick 
near such a place. Sometimes they had luck, just like a fellow prophesying."

\section{WHAT LEARNED MEN SAY ABOUT IT}

This 'divining-rod business is no modern affair let me state. That great book of knowledge, the Britannica, devotes a page to the subject and gives out that it is apparently of immemorial antiquity. It wasn't started by our farmers in the bush, oh, no, and it is of more than mythological or superstitious interest.

From the Britannica I quote the following: "Prof. W.F. Barrett, F. R. S., the chief modern investigator of his subject, regards its employment, dating as it does from the revival of learning, as based on the medieval doctrine of 'sympathy,' the drooping of trees and character of vegetation being considered to give indications of matters beneath the earth's surface, by means of a sort of attraction." "Making a liberal allowance for failures of which I have not heard," writes Prof. Barrett, "I have no hesitation in saying that where fissure of water exists and the discovery of underground water sufficient for a domestic supply is a matter of the utmost difficulty, the chances of success with a good dowser far exceeds mere lucky hits, on the success obtained by the most skilful observer, even with a full knowledge of the local geology."

The Encyclopedia editor adds: "Is this due 
to any special faculty in the dowser or has the twig itself anything to do with it? Held in balanced equilibrium the forked twig, in the dowser's hands, moves with sudden and often violent motion and the appearance of actual life in the twig itself, though regarded as mere stage-play by some is popularly associated as the.cause of the waterfinder's success. Like the 'homing instinct' of certain birds and animals, the dowser's power lies beneath the level of any conscious perception; and the function of the forked stick is to act as an index of some material or other mental disturbance within him, which otherwise he could not interpret."

Another authority states: Dowsers sometimes do not use any rod. Some again use a willow rod or withy, others a hazel twig, others a beech or bolly twig or one from any other tree. It is repudiated that any electric force is involved, that water-finding is due to mechanical vibration set up by the friction of the moving water acting upon the sensitive ventral diaphragm of certain delicately framed persons through the medium of the twig used.

There you have what the bulging foreheaded chaps have to say on the subject, but there are modern scientists who hold that there is nothing in the theory or "alleged" science of water-finding at all. Maybe these latter are in the pay of welldrilling outfits and windmill and pump manufacturers, who knows? 
In early days on the farm, when fencing was more difficult, there was not always a lane extending from the farmyard to the back fields. The young stock were usually pastured at the back end of the lot and in the bush. In the spring and early summer there would be enough of surface water in swales or ponds to water the young animals but, later in the season, this source failed. Usually there would be a shallow well by the edge of the bush from which the younger members of the farmer's family would be required to dip the water daily with a pail and rope for the young cattle. One pump might be considered a necessity on the farm then, but two were a luxury-mostly denied.

\section{THE BIGGEST DOG AND 'COON FIGHT EVER}

I recall that on our farm there were two such bush-side wells, without pumps. One day as I had proceeded, unwillingly, no doubt, to perform the daily task of pulling up water with a pail for a thirsty herd of young critters, I discovered that one of the wells had gone dry and that the biggest 'coon I ever saw was a prisoner at the bottom of that well. It was a dry season and the ring-tailed denizen of the corn patch, like the fox in the fable, had jumped down the well without considering how it was going to climb out. There was, per- 
haps, a bucket of water in the well and a liberal quantity of mud and the 'coon had mixed these elements together in its efforts to escape. A favourite dog of my boyhood days was with me, a mongrel canine, but full of fight, and before I could prevent-if I'd been so disposed-there was a tussle going on in the bottom of that well, that beat anything for fierceness of detail that I've ever known.

\section{AN OLD STORY RECALLED}

You've heard that story about the old hunter who encountered a big bear and was armed only with a knife. There was no way out but to fight and the old man was a little bit nervous about the outcome. He had not been in the habit of invoking Divine aid in his earthly undertakings and when he'd come up against what looked like serious trouble he felt it would be somewhat cowardly to call for help when he'd been in the habit of relying on his own resources in fair weather.

"If ye can't help me, don't help the bear. Jest remain neutral an' ye'll see one of the biggest fights ever tuk place," was the prayer he offered.

I had to remain on the edge of that well a neutral, so far as material help was concerned, and I certainly did see "one of the biggest fights ever tuk place," between a dog and a 'coon. - It lasted, I suppose, half an hour. I cried, prayed and yelled in turns. Couldn't tell which from t'other; 
nohow, because both animals were soused in mud from head to tail.

BRER 'COON LOST THE FIGHT

Finally I could hear the dog whining and the other thing was still, and hurriedly putting a couple of rails down into the well, slantways, I descended and assisted my old faithful out. I threw the remains of Brer 'Coon up out of the death-pit and soused some water from another well over the dog and his late antagonist. You should have seen that boy and his dog, the former holding a wet, muddy dead 'coon by its tail, over his shoulder, arriving at the door of the farmhouse kitchen. They'd have made a picture that that famous painting "The Return of the Hunters" would have seemed tame beside.

\section{JUST A YANKEE LIE}

Yes, drawing water with a rope and pail, from even a shallow well, on a sultry August day, was a strenuous task for a small boy. I've read somewhere that, in the United States, where tornadoes are not infrequent happenings, and liars are plentiful, the suction of the wind is so strong that the bottoms of the wells are pulled up several feet and the pumps thus stand away up in the air after a storm. Sounds to me like fiction but I could have wished that something like that had 
happened to our wells that I had to draw water from. I know it's a favourite poem, but those "old oaken bucket" verses, somehow, never appealed to me-always reminded me of drawing water by hand. Reverting to that water-finding art, I recall that I used to hope that the day would come when those dowsers or forked-stick manipulators, would become so expert in their profession that they'd be able to find springs within at least a foot or two of the surface of the earth. 


\section{CHAPTER XVIII: BEE-KEEPING}

MEMORIES OF BEE-REEPING. BEES AN INTERESTING STUDY, VERY. HIVING A "SWARM." TROUSERS FULL $0^{\prime}$ BEES. A BEE ARMY IN ACTION. AN APIARIST WHO HAD TO FLY TO A WHEAT-FIELD FOR REFUGE. HAD BEES IN HIS WHISKERS. SUNDAY SERVICE AT THE VILLAGE CHURCH DISTURBED BY "SWARMING" BEES. 



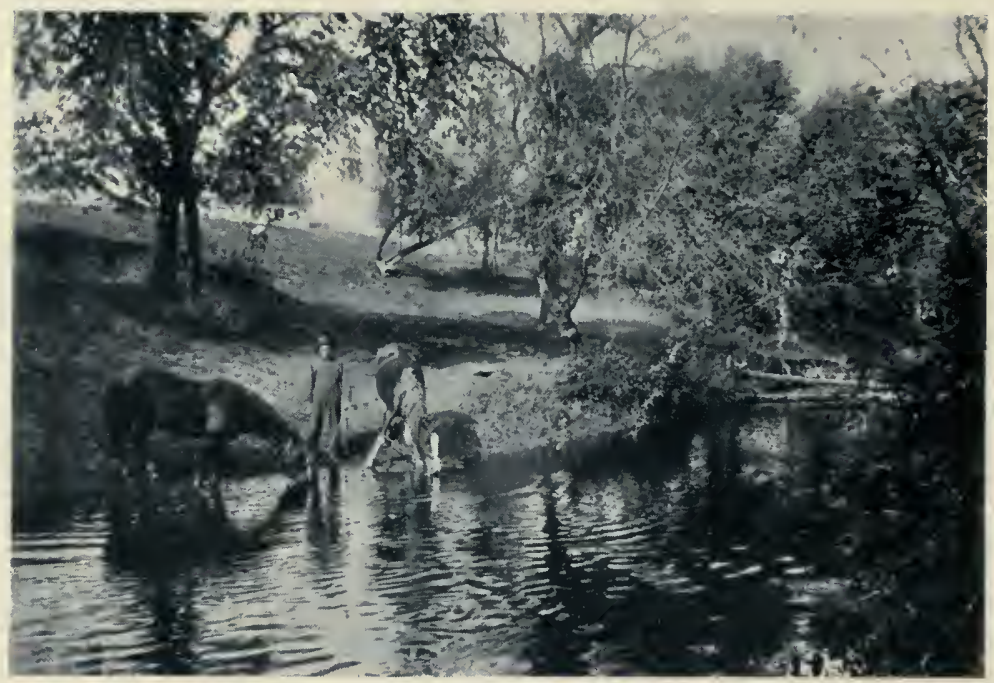

WATERING THE HORSES. 


\section{CHAPTER XVIII}

\section{Bee-keeping}

ANYONE who has ever kept bees-conducted an 1 apiary-should have no difficulty in recalling memorable incidents connected therewith. Memories of bee-keeping, realistically recorded, should properly show a considerable number of exclamation marks. The busy bee, at all events, punctuates certain of its doings with full points and the apiarist may be depended on to furnish the exclamations.

Among my varied experiences down on the farm I have vivid recollections of bees that $I$ have known. As a boy, I was fond of sweets, and revelled in bull's-eye candy and sugar sticks when circumstances would permit. When I was old enough and became learned in the best methods of robbing bumble-bees, I pursued that avocation with enthusiasm. Later I decided to become an apiarist and, later still, I decided that I was too sensitive to continue.

\section{QUALIFICATIONS FOR A BEE-KEEPER}

Briefly put I was not a success in chumming with the busy bee. I was too thin-skinned. To be 
a successful bee-keeper, a book agent, or a politician, one should be able to endure the slings and arrows of outrageous fortune cheerfully and always come up smiling.

As a youth I recall that I pointed out to my father where there was a great wastage on our farm. We were letting a valuable by-product of the clover-fields go to waste. I hinted that, beside making hay, we should be harvesting honey and he fell for my honeyed words and bought me several hives of bees and all the paraphernalia appertaining thereto.

\section{BEES AN INTERESTING STUDY, VERY}

I read a big book entitled, "The Bee-keepers' Manual," and proceeded to cultivate the acquaintance of my improve-the-shining-hour insects, and I may state right here that I formed a very close acquaintanceship with quite a number of them. They say it is a very interesting study to consider the bee. It may be but I could never bring myself to that way of thinking, at least not to consider the bee at close range after a certain incident occurred.

I've been told, or have read somewhere, that the best bees come from Italy, perhaps that's where these hard-working little fellows learned to become so handy with the stiletto.

I got along fairly well in the beginning-that is, I managed to keep one eye good most of the time, but often my face was lop-sided and I recall that 
I had to stay at home once from the annual picnic of the neighbourhood because I was "such a sight." Face all swelled up so at times, that my own mother didn't know me.

\section{HIVING A "SWARM"}

I had robbed the hives-that is, I had extracted the honey and put the comb back to be refilled and had got through the stealing or robbing operation fairly well, when, one day, an over-crowded hive decided to "swarm." That means that the old queen and her retainers were quitting the hive to seek new quarters and thus allow the young queen and brood room to work. I had talked with beekeepers in order to be prepared for such an emergency. But there are no lessons learned from books or talk, that quite take the place of learning in the school of actual experience. That goes with other affairs beside bee-keeping.

\section{TROUSERS FULL OF BEES}

I came a-running to hive that swarm of bees. I had on a veil, of course, and gloves fastened tightly about my wrists. The swarm had left the hive and were hanging clustered on the limb of a nearby apple-tree. The air about was full of buzzing bees and thousands had dropped off the cluster to the ground. I had a big pail and as gently as possible, I cut off the limb allowing the overflow to drop into the pail. For a time it looked 
as if everything was going along swimmingly. I've remarked that there were a lot of bees in the grass and those were the chaps that caused my overthrow. I should have tied my trousers at the bottom or have pulled my socks over the bottom ends of my trousers. In my haste I omitted this and many, yes, very many, bees crawled up and on the inside of those pantaloons.

As long as you give bees plenty of sea room, on such an occasion, they are not inclined to get cross but the minute the fussy little fellows get tangled up, why, results may be looked for. I felt a sting on the knee, then another, then a whole volley at once, then shrapnel, machine guns, quick firers and every other form of musketry and artillery that a well-drilled army of bees knows how to bring into action, got busy on my lower extremities.

And all because I had forgotten to pull those sturdy wool socks of decency, that I wore, over the ends of my trouser legs. I use the term "wool socks of decency," because in those good old days, neither boys nor girls, nor men nor women invested their nether limbs in those gauzy "alleged" socks or stockings worn by many folks to-day.

\section{A BEE ARMY IN ACTION}

Talk about stumbling on a hornet's nest! I was in a tight corner, indeed, and as long as memory lasts I will not need to prod myself to recall 
the sensations that enveloped me. A pailful of bees in one hand, a small branch with several quarts of bees hanging from it in the other and two trouser legs full of bees-beside, bees behind, right, left, overhead and underfoot. Was it any wonder that I grew nervous? I've heard that there are certain men who become nervous in the presence of large sums of money. As I've never been in such a situation I cannot say how it would affect me, but I recall distinctly, that my being placed in the midst of those buzzing thousands just about unbalanced me mentally.

\section{TOOK REFUGE IN THE WHEAT-FIELD}

The farmhouse was only a few rods away but I could not beat a retreat in that direction. There were two young ladies from the city visiting at our home that day, and I just couldn't bring myself to make an appearance before them as I should have had to do to reach my room. I threw the pail of bees in one direction, the bee-festooned branch in another and cleared the orchard fence in a flying leap that would have won plaudits for a hurdle racer. Across the fence was a fall wheatfield with the grain four or five feet in length. That was my haven.

\section{A HURRIED DISROBING}

Perhaps you've seen a small boy shed his clothes when he's trying to beat the other fellows 
into the old swimmin' hole. That's the speed with which I disrobed in that wheat-field and there were none of those bees that were in my trousers when I flung them off that ever returned to the home hive again. I killed them all-no quarter. Wanton murder, you say, well, maybe so, but please remember too, the provocation.

\section{BEE-HISTORY}

It is said that to handle bees successfully one must know something of the life history and makeup of the different hives. I recall that some one once asked an old lady why she did not read history and she replied that she believed in letting bygones be bygones. That's the attitude I hold now toward bee-history. I'll eat honey but a team of strong oxen couldn't haul me in the direction of a hive of bees in the swarming season.

Here's a brief bee-history of those who may want it!

In each colony there is a queen, several hundred drones, and between forty and fifty thousand worker bees. The queen lives from two to four years, leaves the hives only on her mating flight and when she takes out a swarm. During the rest of her lifetime she attends to the replenishing of the colony with the necessary workers and drones. In season she lays eggs, often as many as 2,000 or 3,000 a day. The drones live from five to six months, they do no work and are useful only for 
the mating of queens. At the end of the season the bees kill them and cast them out of the hives. The worker bees live only about six weeks when the honey flow is on, literally working themselves to death. When they cannot work, as during the winter months, they may live for six months.

\section{THE YELLOW-BREECHED PHUOSOPHER}

Ralph Waldo Emerson, poet and wise man generally, addressed some pretty verses to the bumble-bee, one of which runs :

6
"Wiser far than human seer,
Yellow-breeched philosopher!
Seeing only what is fair,
Sipping only what is sweet,
Thou dost mock at fate and care,
Leave the chaff and take the wheat.
When the fierce northwestern blast
Cools sea and land so far and fast,
Thou already slumberest deep;
Woe and want thou canst outsleep;
Want and woe which torture us,
Thy sleep makes ridiculous."

\section{BEES IN HIS WHISKERS}

I have seen old men puttering about bee-hives seemingly as happy and unconcerned as if they'd been walking about a flower garden or orchard. Knew just how to cultivate friendly acquaintance with the little busybodies, but to me bees are too 
erratic to make bosom friends of. A relative of mine, a big strong man, was once stung on the neck, just above the carotid artery, by a bee, and in less than a minute, he-the man-became unconscious and remained in that condition over an hour. The poison injected into his jugular vein had been carried to his heart with well-nigh fatal results.

I recall that when I was a schoolboy, along with other youngsters, I used to pass by, every day, a house by the side of the road, in the garden adjoining which an elderly man, who wore whiskers, was often to be seen about his bee-hives. I remember, on one occasion, some young scamp banged an apple, a stone, or a clod of earth, against a hive, by which the old gentleman was fondly lingering. I can see that old chap yet tearing at those whiskers and hear him fracturing the atmosphere, not with honeyed, but unprintable words.

\section{BEES BROKE UP THE OHURCH SERVICE}

The village church that I attended in my youthful days was once the scene of a lively encounter with bees. The sacred edifice was a long, homely, frame structure with hard, unbendable and severely straight-backed seats of heavy pine. Like most pioneer public buildings it was poorly heated. A great box-stove stood near the door, and a long, uneven pipe was carried along the ceiling to the 
chimney back of the pulpit, with tin cans suspended here and there to catch the sooty drip. In winter the temperature was likely to be low any distance from the stove. But the ministers preached warmer sermons than is customary now. Then there was no question as to where the wicked and unrepentant would find themselves after their earthly pilgrimage was o'er. There was no hedging by the preachers on this point. They spoke of hell, the fiery furnace, and the lake of fire and brimstone with decision and definiteness. On cold days, even a worshipper with dull imagination could keep warm under the influence of such argument, and with such picture of impending fate. But in the good old summer-time the windows would be opened wide. The village postmaster, whose little store was just across the road, kept bees, and, while he was at church, a "swarm" left the hive. It located on the limb of an appletree, the branches of which hung over an open window of the church. In their buzzing about, several thousands of these little busy bees, instead of improving the shining hour by finding a fit and proper place to begin business, drifted into the church through that open window. I shall not attempt to give details of what actually happened, but it may definitely be stated, that there was no collection taken up, and no benediction pronounced that Sunday.

I've heard of an old-time preacher who used to bang the pulpit real hard in his efforts to em- 
phasise his arguments and awaken the apathetic from their slumbers. A hive of bumble-bees had built their nest in the pulpit. A particularly hefty blow on the pulpit top brought forth results in the form of a horde of angry bees and of course these attacked the preacher. Giving vent to a distracting yell he cleared the pulpit at a bound and made for the exit. Those in the pews thought their pastor had suddenly gone insane, but when the bees began to widen the extent of their operations, the congregation, too, stood not on the order of their going, but went pell-mell.

That fine old Quaker poet, John Greenleaf Whittier, among other gems of verse left behind an exquisite little poem entitled, "Telling the Bees." This remarkable custom of "Telling the Bees" prevailed in the rural districts of New England in Whittier's days. The custom was brought from the Old Country. On the death of a member of the family, the bees were at once informed of the event and their hives dressed in mourning. This ceremonial was supposed to be necessary to prevent the swarms from leaving their hives and seeking a new home.

In earlier days it was not unusual for a woodsman to find a "bee" tree in the winter-that is a tree where a colony of bees had made their home - and there was often much honey to be had from such trees. It was, of course, quite safe to harvest the honey as the bees would be in a dormant condition. 


\section{Bee-keeping}

In early days both in the United States and some parts of Canada there were men who made a regular business of locating "bee" trees in the summer season and marking these so that the honey might be taken in the winter. 



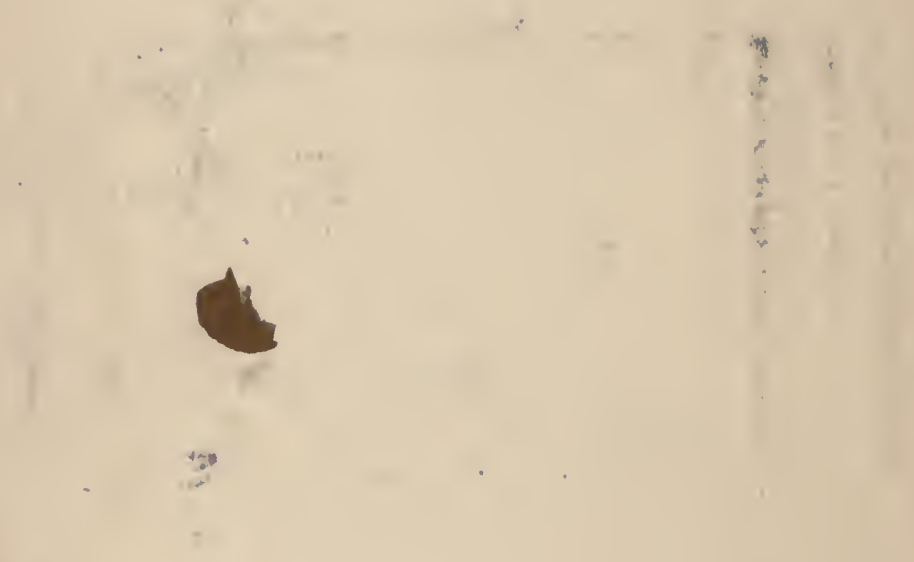
$S$

521

W65

BioMed
Wood, A. C.

Old days on the farm

\section{PLEASE DO NOT REMOVE}

CARDS OR SLIPS FROM THIS POCKET

\section{UNIVERSITY OF TORONTO LIBRARY}


